\title{
Galvanizing Germantown: The Politicization of Louisville's German Community, 1848-1855
}

Ann Kathryn Fleming

West Virginia University, akf0005@mix.wvu.edu

Follow this and additional works at: https://researchrepository.wvu.edu/etd

Part of the American Studies Commons, Cultural History Commons, European History Commons, Labor History Commons, and the Social History Commons

\section{Recommended Citation}

Fleming, Ann Kathryn, "Galvanizing Germantown: The Politicization of Louisville's German Community, 1848-1855" (2020). Graduate Theses, Dissertations, and Problem Reports. 7567.

https://researchrepository.wvu.edu/etd/7567

This Thesis is protected by copyright and/or related rights. It has been brought to you by the The Research Repository @ WVU with permission from the rights-holder(s). You are free to use this Thesis in any way that is permitted by the copyright and related rights legislation that applies to your use. For other uses you must obtain permission from the rights-holder(s) directly, unless additional rights are indicated by a Creative Commons license in the record and/ or on the work itself. This Thesis has been accepted for inclusion in WVU Graduate Theses, Dissertations, and Problem Reports collection by an authorized administrator of The Research Repository @ WVU. For more information, please contact researchrepository@mail.wvu.edu. 


\title{
GALVANIZING GERMANTOWN: THE POLITICIZATION OF LOUISVILLE'S GERMAN COMMUNITY, 1848-1855
}

\begin{abstract}
Ann Kathryn Fleming
Thesis submitted to the Eberly College of Arts and Sciences at West Virginia University in partial fulfillment of the requirements for the degree of Masters in History
\end{abstract}

\author{
Katherine Aaslestad, Ph.D., Chair \\ Joshua Arthurs, Ph.D. \\ Kenneth Fones-Wolf, Ph.D. \\ Matthew Vester, Ph.D. \\ Department of History
}

\section{Morgantown, West Virginia 2020}

Keywords: German immigration, Revolutions of 1848, republicanism, forty-eighters, radicalism, Know-Nothing party, migration studies

Copyright 2020 (Ann Kathryn Fleming) 


\begin{abstract}
Galvanizing Germantown: The Politicization of Louisville's German Community, 1848-1855 Ann Kathryn Fleming
\end{abstract}

This project interprets the Revolutions of 1848 and their ideological legacy through a transnational and transcultural context, highlighting the role of radical forty-eighters who imparted their republican messages to "Little Germanies" within the United States. Karl Heinzen serves as the primary example of the transient group that shared their radical visions with local German communities populated with political and cultural organizations, an active press and a commitment to civic engagement demonstrated through their involvement anti-slavery groups, labor reform, and improved rights for the immigrant population.

The thesis traces the politicization of Karl Heinzen in the German Confederation and his involvement in the Revolutions of 1848 in Baden. Through an examination of his publications, it reveals his radical republican political beliefs shaped by the events in 1848 . Once in the United States, Heinzen, now an émigré, edited a German press in Louisville, Kentucky, a slave state. In fact, slavery inflamed most revolutionaries, including Heinzen, and galvanized their reform agenda. It was here that he and other fellow radicals composed the Louisville Platform, a document that advocated reform based on a republican world view related to the goals of the 1848 Revolution in contrast to the individualist liberal republicanism evident in the United States. The Platform pointed out the weaknesses and corruption in the American political system and called broadly for expanded and equal human rights to immigrants, women, slaves, and free African Americans. This Platform and Heinzen's work empowering the German community challenged the popular anti-immigrant Know-Nothing leaders of the city generating growing hostility and accusations of conspiracy and danger to the American Republic through the unreserved cultural and linguistic expression of their flourishing and self-sustaining community.

As in Baden in 1848, the politicized German population of Louisville asserted their right to vote on August 6, 1855. Local Know-Nothing gangs retaliated by murdering and assaulting immigrants, as well as burning entire sections of their communities to the ground. The tragic events of this day represent fundamentally different views on the nature of the American Republic, one that highlighted human rights and another that advocated rights solely for the native born.

This thesis reveals, in the person of Karl Heinzen, the transmission of a radical republican world view that stemmed from popular opposition to a corrupt and inept monarchy and that made its way to the United States with 1848 émigrés. In the United States, such reform goals become expressed in German communities in their press, organizational life and political agendas to reveal the republican legacy that immigrants brought with them to the United States from the aftermath of the uprisings in German Central Europe. Heinzen, who sought progressive reforms and republican ideals in another country, agitated a new nativist enemy that viewed German republicanism as fundamental threat to the American way of life. 


\section{Acknowledgments}

Finished products are born out of the work, assistance, and encouragement of many. Therefore, I first must convey my deepest gratitude for Dr. Katherine Aaslestad, the historian and educator who helped me the most in my two years at West Virginia University. She must be thanked not only for her guidance on this project, but for her role as a mentor to a student of history like myself. Dr. Aaslestad's contributions to my success do not end with her constructive criticism and suggestions for improving my papers. Indeed, serving as her advisee is a precious role that all students would be lucky to experience. Not only has she inspired me as an instructor and advisor, but her nurturing spirit has also kept me above water even in the darkest hours of my career as a Masters' student. As I move forward in my education and career, I will never take for granted this time of personal maturity and academic growth with such an influential scholar, and wish to serve in the same role to another young and curious student one day.

I would also like to show appreciation for the members of my committee and their stimulating questions that ultimately pushed this thesis to its current improved condition. Key themes within the courses that I took with them, such as Dr. Fones-Wolf's Working-Class America and its partial focus on immigrant-led political movements, prompted the creation of entire sections of this project. In addition, Dr. William Gorby's American Immigration History provided further ideas that proved essential for the completion of this thesis.

The graduate students who took those classes as well as others along with me should also be thanked for the conversations, venting sessions, and camaraderie that we shared during my time in the department. We were all in this together, and provided advice, direction, and suggestions through this whole process of finishing our theses and acquiring our Masters' degrees. Certainly, some of my most important and sincere friendships were developed during these two years of my life.

In addition, the research librarians at WVU--though not part of the History Department-provided unconditional support as well as a wonderful and cordial work environment in my two years at Research Services in the Downtown Campus Library, and I could not have asked for a better Graduate Assistantship opportunity, or supervisor than Alyssa Wright. Specifically, Interdisciplinary, Cultural, and Film Studies Librarian Beth Toren has since become an incredible mentor and dear friend. Serving as her Teaching Assistant provided significant insight into the skill of teaching that I will need when I, too, take on the role of instructor. Our conversations on movies, television shows, and celebrity gossip also kept me eager to go into work every day.

Last and most personally, I wish to thank my family for their unconditional support, love, and understanding. Mom, I appreciate that you have read every single paper that I have ever written throughout my college and graduate career. Unfortunately for you, this trend will not end as I continue on to acquire my Ph.D. Dad, your pride in me and the fact that you are always there for me is part of the reason that I strive so hard to succeed. Jacob, I could not have achieved that success without you by my side. 


\section{Table of Contents}

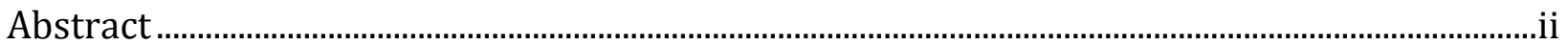

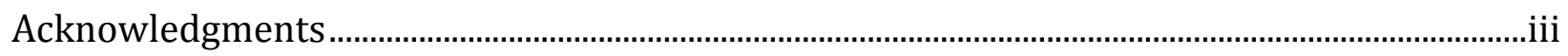

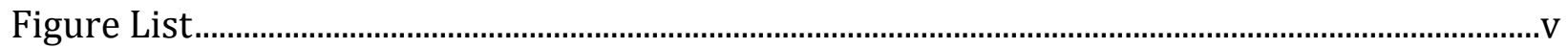

Introduction: The Revolutions of 1848 and Rising Republicanism in Baden...............................

Chapter I: The Politicization of Karl Heinzen and Arrival in Little Germanies in the U.S.......23

Chapter II: The Louisville Platform as a Roadmap for Republicanism .......................................64

Chapter III: Rallying Rhetoric and Local Collisions of Republicanism ......................................94

Conclusion: The Transnational and Transcultural Legacy of the Revolutions of 1848 ........138

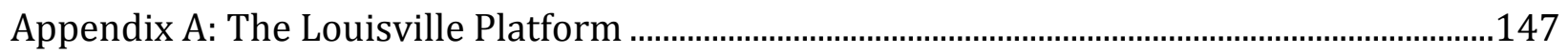

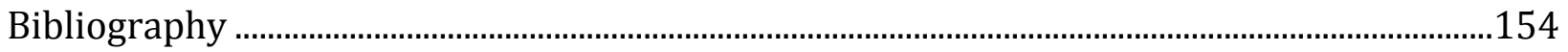




\section{Figure List}

Figure 1: Portrait of Karl Peter Heinzen ...........................................................................22

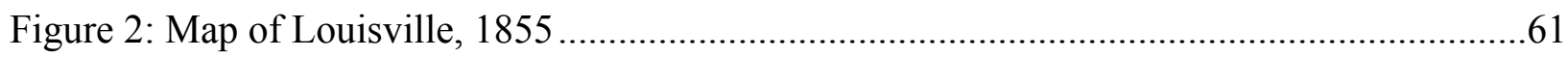

Figure 3: St. Martin of Tours Cathedral ...........................................................................61

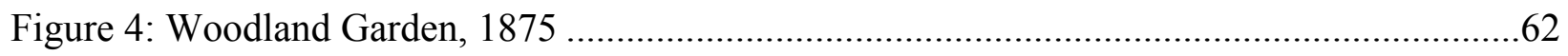

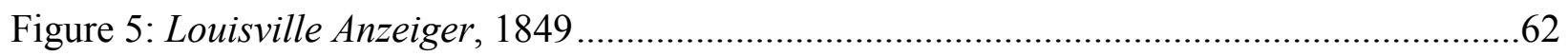

Figure 6: Louisville's Liederkranz Hall ...................................................................63

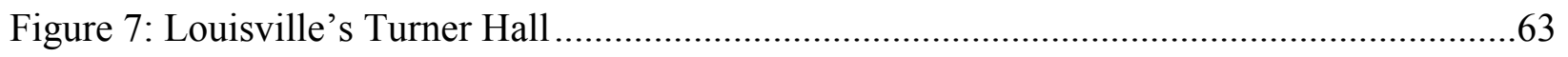

Figure 8: "A Paper Entitled the American Patriot," 1852 ...................................................92

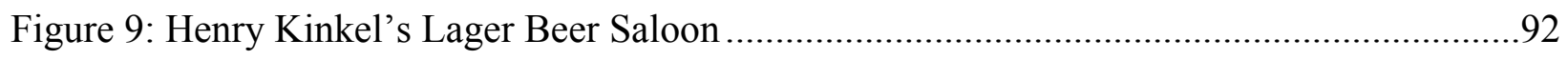

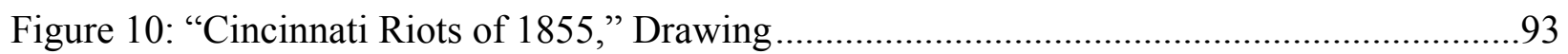

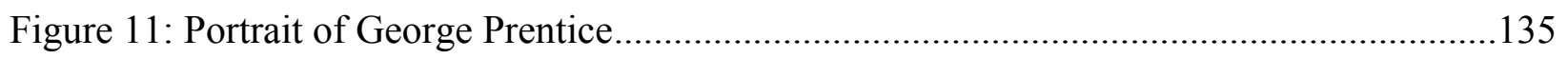

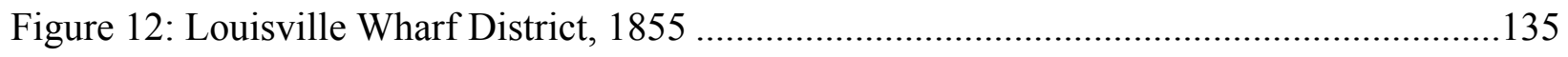

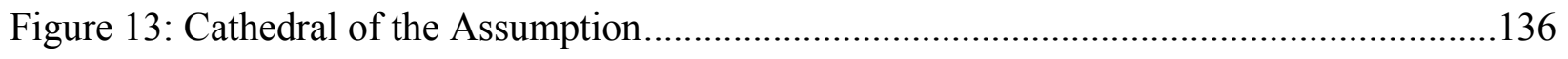

Figure 14: "Bloody Monday Riots on Shelby Street near Becker’s Bakery,” Drawing.............136

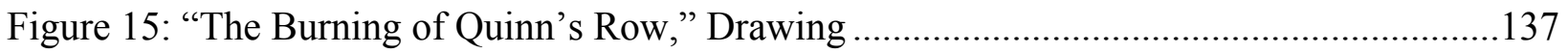




\section{Introduction: The Revolutions of 1848 and Rising Republicanism in Baden}

In March of 1848, the month that riots erupted throughout German Central Europe, Karl Heinzen (pictured in Figure 1 at the end of the chapter) had been in the United States only a few months, forced out of all other countries that had previously granted him asylum. A letter sent on the SS Cambria arrived from fellow political refugee and poet, Ferdinand Freiligrath, who wrote enthusiastically that "the bomb has exploded! Paris, Europe is in flames."1 Included in this correspondence was a poem that signaled a call to action from liberals across the Atlantic, and Heinzen promptly published this piece in New York City's Deutsche Schnellpost, the newspaper that he first edited in the United States. Indeed, Freiligrath's poem was shared in many Germanlanguage newspapers throughout the country, encouraging German communities everywhere to commemorate "the liberation of Europe."2 Much of this sentiment, like the inspiring poem's lyrics, contained dramatic descriptions of victories that, by 1849, proved short-lived.

Nothing, however, could mollify the excitement of German speakers on the North American continent when word spread regarding the outbreak of uprisings in the German Confederation. The subsequent establishment of constitutions in many states, as well as the freedoms debated among the people shortly thereafter, appeared to prove that unchecked monarchism had seen its final day. This occasion created poets out of regular GermanAmericans, who submitted their own soliloquies celebrating the revolution to their local newspapers. ${ }^{3}$ Indeed, newspapers sprang up across the country within German neighborhoods, including Louisville, Kentucky, where the weekly liberal Anzeiger converted into a daily due to high demand for news of developments back in the Heimat. A German "Patriotic Society" hosted

\footnotetext{
${ }^{1}$ Carl Wittke, Refugees of Revolution: The German Forty-Eighters in America (Philadelphia: University of Pennsylvania Press, 1952): 29.

2 Wittke, Refugees of Revolution, 29.

3 Ibid.
} 
concerts, the proceeds of which were sent back to the German lands and also provided for political refugees like Heinzen who returned to join the revolution. A Lieder, or singing troupe, was created in the memory of Robert Blum, a revolutionary executed by Austrian forces in Vienna. Reactions soon became visible in the city's landscape when a German Lokal owner renamed his bar to "Deutsche Republik."

Hundreds of community-based organizations were established throughout American cities to aid in the success of the uprisings. These examples speak to the strength of German community as captured significantly in festive culture during this time, highlighted in Jürgen Heideking's influential article. ${ }^{5}$ Not far from Louisville, a group of women who resided among Cincinnati's extensive German population sewed a red, black, and gold flag as a gift to the first German state to declare a republican government. In St. Louis, nationalities representing almost all rebelling corners of Europe—Poles, Frenchmen, Italians, Irish, as well as Germans—-hosted a massive parade in the streets of their boroughs. German-Americans and other immigrant groups were eager to participate in their homelands' revolutions from thousands of miles away for as long as liberal governments maintained their stamina. Approximately one year later, however, these very revolutionists appeared in North America as political refugees and, like Heinzen, carried their visions of republicanism to foster new reforms in the United States.

\section{Methodology and Terminology}

Karl Heinzen's journey before, during, and after this tumultuous period personalizes and propels this study on migration following 1848 . His role in the revolutions of Baden, postmigration activism, and the series of challenges raised by anti-immigrant nativists in the border

\footnotetext{
${ }^{4}$ Ibid, 34-35.

5 Jürgen Heideking, "Festive Culture and National Identity in America and Germany, 1760-1860," in Republicanism and Liberalism in America and the German States, 1750-1850 (Cambridge: Cambridge University Press, 2002).
} 
region of the United States appropriately fulfills Harzig and Hoerder's framework for a more thorough and legitimate case study within migration history. This transnational study, therefore, highlights migration as it links individual experiences and ideas between political spaces, if not nations. This transnational movement reveals that the most outspoken forty-eighters continued to articulate their belief systems and fight for reform in their news homes and, in the process, guaranteed that the republican messages inherent within the Revolutions of 1848 could make an impact on another continent.

As a transnational study it is appropriate to clarify my methodology and terminology, as well as the framework that I utilize to this story of migration. Karl Heinzen's travels across the Atlantic and his political influence on two continents are best framed by Christiane Harzig and Dirk Hoerder's systems' theory. This approach was inspired by the "reintroduction" of transnationalism by American anthropologists and sociologists at the very end of the twentieth century. ${ }^{6}$ In Towards a Transnational Perspective on Migration, Nina Glick Schiller, Linda Basch, and Cristina Blanc-Szanton popularized the term once more "in the migration and globalization discourses."7 In this case, transnational "refers to continuities in migrants' experiences," which may include kinship networks through family and friends, retainment of cultural and linguistic practices, as well as economic endeavors. ${ }^{8}$ In the case of German migration in the mid-nineteenth century, all examples of transnationalism as defined above are evident and common. For this project, however, ideas and belief systems serve as the most important examples of transnational continuities between countries of origins and destination. David Thelan elaborates that "ideas" and the people who hold them "do not have clear national

\footnotetext{
${ }^{6}$ Christiane Harzig and Dirk Hoerder. What is Migration History? (Cambridge: Polity Press, 2009): 84.

${ }^{7}$ Harzig and Hoerder, What is Migration History? 84.

${ }^{8}$ Ibid.
} 
identities." In other words, "instead of assuming that something was distinctively American...we might assume that elements of it began or ended somewhere else." 10 This project utilizes such an interpretation of migration studies to theorize that the ideas of republicanism espoused by revolutionaries in German Central Europe during the Revolutions of 1848 were transferred by exiles and immigrants alike to the United States, making a significant challenge and contribution to the United States and democracy for decades to come.

Harzig and Hoerder, however, do not incorporate the idea of "territories as basic units."11 Instead of thinking in national terms, they focus on transregional exchanges between sites of origin and destination. Thus, studies of political refugees like Heinzen also benefit from the balancing of "micro-, meso-, and macro-regional perspectives," or an emphasis on the local spaces on which they impacted during their revolutionary years. ${ }^{12}$ From transregional conceptualizations stems transcultural studies that Hoerder describes as the connection of "multiple spaces in which people live and interrelate and which transcend political boundaries."13 The intensive study of these spaces in the life of an immigrant "denotes the competence to live in two or more differing cultures and, in the process, to create a transcultural space of destination, [as well as] connections to other spaces." ${ }^{14}$ Individuals who migrate are in this case viewed as possessing the agency to interact and organize with others in their daily lives, and to utilize experience from their homelands to improve their status in a new country. They therefore are understood as having the capability "to plan and act life-projects in multiple

\footnotetext{
${ }^{9}$ Ibid. Originally in David Thelan, "Of Audiences, Borderlands, and Comparisons: Toward the Internationalization of American History." Journal of American History 79 (1992): 436.

${ }^{10}$ Ibid. Originally in David Thelan, "Of Audiences, Borderlands, and Comparisons," 436.

${ }^{11}$ Ibid.

${ }^{12} \mathrm{Ibid}, 87$.

${ }^{13} \mathrm{Ibid}, 85$.

${ }^{14}$ Ibid.
} 
contexts and to choose" the roles that they will adopt or transform in another place. ${ }^{15}$ The impact of the forty-eighters and their supporters on American politics and society at a local or regional level is therefore best analyzed through the continuities and beliefs and ideas shared between the sites of origins and of arrival by way of those who espoused them. ${ }^{16}$

Immigrants themselves also require proper defining. My work explores Heinzen as a refugee, exile, and immigrant, from a radical fleeing warrants authorized by European states to an activist in a German-American community energetically sharing his views on republicanism. All of these terms require some attention. There are many terms applied to classify transient peoples who cross borders as they depart from and enter into different national and imperial spaces. Terms like refugee, exile, and immigrant developed respective meanings related to their historical context, just as in our time "political refugee" and "economic migrants" are categorized to reveal a distinct status and even hierarchy of desirability to demonstrate that some migrant are considered advantageous to their new homes and others an imposition. It is important to know that in the context of my project, these three categories of migrant were more clearly defined in Europe than the United States. Within Europe, the meaning of "refugee" expanded in the early nineteenth century during the revolutionary era to emphasize forced migration as search for sanctuary. It suggested that these people were victims of predicaments out of their control that forced them to flee their homelands.

"Exile" implied a similar but less sympathetic fate, as one driven from their home to find another. In most traditional scholarship the term immigrant focused on the shift from transient to

\footnotetext{
15 Ibid. See also Dirk Hoerder, "From Interest-Driven National Discourse to Transcultural Societal Studies," in Dirk Hoerder, From the Study of Canada to Canadian Studies: To Know Our Many Selves Changing Across Time and Space. (Augsburg, 2005): 316-26.

${ }^{16}$ Ibid. For a more thorough account of the evolution of these ideas on transcultural societal studies, see Dirk Hoerder, "Changing Paradigms in Migration History: From 'To America' to Worldwide Systems." Canadian Review of American Studies 24.2 (1994), 105-126; A.J. Mabongunje, "Systems' Approach to a Theory of RuralUrban Migration." Geographical Analysis 2.1 (1970), 1-18; J.J. Mangolam and H.K. Schwarzweller, "General Theory in the Study of Migration: Current Needs and Difficulties.” International Migration Review 3 (1968), 3-18.
} 
adaptation to a new national space and culture instead of the retention of connections and linkages between spaces. ${ }^{17}$ This emphasis is partly due to scholarship shaped by the hegemony of the national paradigm. For example, recent studies of migration point out that migration is often more a way of life than a one-way transition from one national identity to another. For this reason, the term "diaspora" is used by migration historians to emphasize the transnational and transcultural nature in migrant lives and communities. ${ }^{18}$

In this study, Karl Heinzen is first an exile in Europe, then a refugee fleeing persecution following the Revolutions of 1848, and finally an immigrant who settles into several German diasporas within the United States throughout his life. His transformation in status reflects the lack of definite terms within American immigration policy at that time, and thus the ability to shed one identity for another based on his desire to take on a leadership role within GermanAmerican political activism. The fluidity of these terms demonstrates that migration from one state to another can both threaten and improve the immigrant's new home.

Furthermore, the term "German-American" is also problematic, and thus requires some attention, as well. Until the First World War, German remained a cultural rather than a national identity given the fact that a German state had not emerged until 1871. In addition, German immigrants to the United States came from a variety of regional, religious, socio-economic, and political backgrounds. Their settlement into areas populated by other German speakers, however, resulted in the prospect that shared language and cultural practices could indeed unite the diverse German element of the United States. Establishing an identity in a foreign and perhaps hostile

\footnotetext{
${ }^{17}$ For a more thorough analysis of these three terms, see Donna Gabaccia, “' Is Everywhere No Where?' Nomads, Nations, and the Immigrant Paradigm of American History." Journal of American History 86, no. 3 (1999): 111534, as well as the following works, Hidetaka Hirota, Expelling the Poor: Atlantic Seaboard States and the Nineteenth Century Origins of American Immigration Policy (New York: Oxford University Press, 2017); Daniel Kanstroom, Deportation Nation: Outsiders in American History (Cambridge: Harvard University Press, 2007); and David W. Haines, Safe Haven?: A History of Refugees in America (Sterling, VA: Kumarian Press, 2010). ${ }^{18}$ Gabaccia, "“Is Everywhere No Where?"” 1124.
} 
environment is an open-ended, never completed process. For example, many scholars believe that group identities like "German-American" emerged from the press, novels, and even festive culture. ${ }^{19}$ As readers, Germans could identify or misidentify with specific cultural stereotypes that flagged a German or American characteristic. Furthermore, along with the important role of the press, hyphenated identities like "German-American" also related to shared immigrant persecution, such as voter suppression and nativist targeting prevalent by the late 1840s and early 1850s, a major focus in my study.

Before highlighting the role of "German-Americans" and their radical forty-eighter leaders, however, it is important to explain the types of ideas and beliefs that they had brought over from their homelands following the Revolutions of 1848 . These progressive activists transferred their own interpretations of republicanism, a term with a long and rich history that spans the Atlantic world, but had never held a universal meaning. Just as the meanings and practices of republicanism differed on the European continent, it developed its own unique meaning over time in the United States with an emphasis on individualism. For Germans in the early nineteenth century and especially by 1848 , republicanism represented an extreme worldview that rejected the monarchical state and related rigid social hierarchy, believing instead in the equality of humankind, regardless of economic or social background. In other words, all men deserved to share equal legal, economic, and political rights and representation. Furthermore, German republicans as well as Heinzen soon espoused communitarian values that

\footnotetext{
${ }^{19}$ See for example, Annette Bühler-Dietrich, "German-American Identity in the Novels of Heinrich Börnstein and Otto Rupius.” Seminar: A Journal of Germanic Studies 42, no. 3 (2006): 211-228; Brent O. Peterson, Popular Narratives and Ethnic Identity: Literature and Community in Die Abendschule. (Ithaca: Cornell University Press, 1991); and Kathleen Neils Conzen, "Ethnicity as Festive Culture: Nineteenth-Century German America on Parade," in The Invention of Ethnicity. Werner Sollors, ed. (New York: Oxford University Press, 1989): 44-76.
} 
claimed that a state should be designed to protect the weak and vulnerable, ensuring fairness in the economic realm as well as security in the social realm..$^{20}$

By the mid-nineteenth century, republicanism in the United States diverged from such European interpretations. Instead, many Americans recognized "freedom" as tied to a marketbased society more than based on virtue and equality. ${ }^{21}$ The emergence of this liberal republicanism valued the independence of the individual over that of the well-being of the community and linked personal dependency and economic autonomy with political rights and identity. The self-made man represented a contrast to the purveyor of equal rights and strong state intervention as expressed in the German Confederation at the same time. Opposition to slavery provides a good example of Heinzen's philosophy that developed over time, during his engagement in the Revolutions of 1848 as well as his migration to the United States and ongoing reform activism there. His views on slavery clearly differentiate the distinction in republican world views on both sides of the Atlantic.

The transnational character of Heinzen's life further emphasizes a theme often neglected in favor of interpretations of the 1848 revolutions primarily as moments of attempted nationbuilding. Many of these activists were not so dedicated to the founding of a single German state as much as they desired a true Republic in the homeland. The revolutions, after all, did not begin with heated debates regarding state borders in the Frankfurt Parliament, but on the streets, among people who desired economic and political change in their own region beyond any abstract notion of national development. When it became apparent that hopes for a German Republic had

\footnotetext{
${ }^{20}$ For more on the growth of republicanism in German Central Europe and its subsequent spread to the United States, see Republicanism and Liberalism in America and the German States, 1750-1850, James A. Henretta and Jürgen Heideking, eds. Cambridge: Cambridge University Press, 2002.

${ }^{21}$ See for example, Daniel Rodgers, "Republicanism: The Career of a Concept." Journal of American History 79, no. 1 (June 1992): 11-38; and Eric Foner, Free Soil, Free Labor, Free Men: The Ideology of the Republican Party Before the Civil War (New York: Oxford University Press, 1970, 1995 ed.).
} 
declined, Heinzen and many other revolutions as well as their supporters promptly took their cause elsewhere for the sake of expanding republicanism and reform.

\section{$\underline{\text { Sources }}$}

To acquire a more thorough understanding of Heinzen's views as they evolved before and after the Revolutions of 1848 , I have drawn on a significant number of his writings as well as others' perspectives housed and digitized in archives in the United States as well as Europe. Last summer, I researched writings on and by forty-eighters who subsequently migrated across the Atlantic at the Berlin Staatsbibliothek. Heinzen's earlier writings, in particular, demonstrate his journey of political radicalization, while those published during the Revolutions of 1848 outline his republican worldview, emphasizing equal rights and denouncing corrupted monarchies across the continent. Furthermore, Heinzen's writings published after his arrival to the United States are also utilized as they articulate many of his principles and values that the forty-eighter gained from his exile. Most importantly, the Louisville Platform demonstrates Heinzen's opinion of the shortcomings of republican ideas and practices in the United States, as well as attempts made on the part of forty-eighters to reform it.

This thesis also examines local and national press in the United States to better understand the treatment that Heinzen, other radicals, and the German-American community as a whole received by Anglo-American communities in a time of intense national tension and turmoil. In Louisville, for example, Know-Nothing supporter George Prentice's Louisville Journal is utilized to convey the negative reception directed toward the local German community based on their lively organizations, political alignments, and especially their relationship to controversial immigrant figures like Heinzen. I incorporate articles from the Louisville Journal 
from the years 1853 to 1855 to emphasize the level of aggression that had built up prior to the intense violence seen on an August election day in 1855. References to the Louisville Anzeiger, the city's most popular German-language newspaper for almost a century, are unfortunately limited to secondary translations. An adequate portrayal of how the Anzeiger's enemies viewed the immigrant-aimed paper is instead provided through the viewpoints of the Louisville Journal as well as other contemporary positions, largely gathered from extensive research at Louisville's Filson Club Historical Society.

\section{$\underline{\text { Radicalism in the Revolutions of } 1848}$}

Analysis of the revolutions of 1848 covers the first stage in Harzig and Hoerder's systems' theory, or that of concentrating on conditions that immigrants faced prior to migration. This stage, Hoerder explains, is a direct challenge to the positivist theory that inaccurately begins the story of migration "at the port of entry." 22 In other words, it is important to adequately survey those "push" factors evident within the country of departure rather than simply bypassing such a stage to focus on the "pull" factors located in the land of destination. Therefore, the origins and outcomes of the revolutions must be explored to understand these immigrants' actions upon arrival in the United States, including their understanding of the social and political flaws in their new homeland. Two sites, one of origin and one of destination, are highlighted as affected by these political, social, and economic transitions. According to Jonathan Sperber, local demands and events embodied calls for reform in the Revolutions of $1848 .{ }^{23}$ The revolutions themselves were a series of uprisings throughout numerous communities, whose origins, political affiliations, and outcomes varied. Before addressing more localized circumstances, however, it is

22 Dirk Hoerder, Migrations and Belongings: 1870-1945. (Cambridge: Belknap Press of Harvard University Press, 2012): 41.

23Jonathan Sperber, The European Revolutions, 1848-1851 (Cambridge: Cambridge University Press, 2005$): 3$. 
important to provide an overview of the tensions leading up to the breakout of revolutions across the region.

Causes for the outbreak of the Revolutions of 1848 included several years of disillusionment, calls for reform, and better government—all of which were interconnected to some degree. Thus, the lead-up to 1848 was a slow process, though the climax itself proved swift and contagious. To begin, the early years of the 1840s, known as the Vormärz within Germanlanguage scholarship, should be examined for all the various turmoil that occurred within a several-years' period across Europe.

The most dismal economic conditions of this period spared only a small number of countries, and interestingly, these were also countries spared much of the revolutionary violence of $1848 .{ }^{24}$ Tying these struggles to many Germans' future activism in the United States, Bruce Levine emphasizes workers as those most deeply affected by the last great European famine that coexisted with a period of industrial recession. Indeed, their numbers had composed the throngs of revolutionary supporters in the streets. A rising industrial economy and the use of unskilled labor threatened institutions like the guilds that had protected their status for centuries. ${ }^{25}$ They interpreted developmental capitalism as a threat to the regulation of their means of production.

Helge Berger and Mark Spoerer highlight the economic roots of the revolutions, arguing that those "factors now tend to be marginalized" to an inaccurate degree in comparison to overall political reforms of the era. ${ }^{26}$ Between 1845 and 1847, the continent suffered from potato blight and other harvest failures, leading to hunger protests in various cities. This, they claim, was the

\footnotetext{
${ }^{24}$ Helge Berger and Mark Spoerer, "Economic Crises and the Europe Revolutions of 1848." The Journal of Economic History 61, no. 2 (2001): 312.

${ }^{25}$ Bruce Levine, "Free Soil, Free Labor, and Freimanner, in German Workers in Industrial Chicago, 1850-1910: A Comparative Perspective. Hartmut Keil and John B. Jentz, eds. (DeKalb, Ill: Northern Illinois University Press, 1983): 166.

${ }^{26}$ Berger and Spoerer, "Economic Crises," 293.
} 
main trigger for working-class revolutionaries "who provided the muscle" in 1848-49.27 Without their activism, the revolutions could not have made a significant impact. In addition, Jonathan Sperber refers to $1845-47$ as a "crisis of transition," a period that consisted of an increase in industrial output amidst crisis in a formerly agricultural economy. ${ }^{28}$

Along with the potato blight, grain prices soared in many areas including France and German Central Europe, disproportionately affecting the lower classes, whose staple foods had mainly included potatoes and grain products. ${ }^{29}$ Increasingly, people spent more of their earnings on food supplies rather than manufactured goods, resulting in an economic downturn for a significant number of private European firms. Crises within the textile industry lasted into the stormy year of 1848 , after the end of the food shortages. ${ }^{30}$ The year 1848 consisted of a surge of strikes throughout the continent, and because "workers protesting in the streets [were] not at their workbenches," the onset of the revolutions themselves may have stymied growth. ${ }^{31}$ The authors conclude that without these economic crises that built up several years' prior to 1848 and mobilized the masses, political revolutionaries would have lacked the "credible threat" of violence that intimidated the aristocracy into submission. ${ }^{32}$ Economic conditions stood in direct relation to and, indeed, only further exposed the necessity for political and social reform.

Scholars from Sigmund Neumman to David Blackbourn and Dieter Langewiesche have emphasized the political and social motivations that led to revolution in 1848. Neumann's early work originally identified three stages outlining this period, beginning with a "wide, liberal,

\footnotetext{
${ }^{27}$ Ibid, 296.

${ }^{28}$ Sperber, The European Revolutions, 109.

${ }^{29}$ Berger and Spoerer, "Economic Crises," 296.

${ }^{30}$ Ibid, 306.

${ }^{31}$ Ibid, 309.

${ }^{32} \mathrm{Ibid}, 319$.
} 
popular base...then taking a proletarian turn, and ending in a consequent reaction." 33 Moreover, David Blackbourn analyzes that the revolutions emerged in regions "most obviously in transition, politically and socially," and thus were the areas "which proved the most explosive" in the outbreak of revolutions in $1848 . .^{34}$

Despite these mass demonstrations, Gerhard Heinz and Dieter Langewiesche characterize the orientation of the revolutions as generally "an attempt to reform the political order in nonviolent fashion." 35 In fact, Langewiesche emphasizes that most liberals' attempted to channel revolutions through legal reform. ${ }^{36}$ Indeed, the events of 1848 shed little blood in comparison to 1793, the despotic consequences of which inspired the revolutionaries' main dependence on "legal means" to accomplish liberal reform. ${ }^{37}$

Aside from shared goals for political reforms, Dieter Langewiesche describes the actions of these revolutionaries as "defined mainly by... inconsistency...and disunited actions." 38 Members of the Vorparlament broke into conservative, center-right, moderate liberal, and radical democratic factions. Politically, these dividing lines often blurred for more common causes, such as the desire to actualize a national state through the creation of "Germany." Brian Vick's cultural and intellectual approach describes these aims to develop a more inclusive definition of German political and cultural identities, rather than the more exclusionist attempts of nationalist

\footnotetext{
${ }^{33}$ Sigmund Neumann, "The Structure and Strategy of Revolution: 1848 and 1849." The Journal of Politics 11, no. 3 (1949): 539.

${ }^{34}$ David Blackbourn, The Long Nineteenth Century: A History of Germany, 1790-1918. (New York: Oxford University Press, 1998): 138.

${ }^{35}$ Gerhard Heinz and Dieter Langeweische, "The European Revolution of 1848: Its Political and Social Reforms, Its Politics of Nationalism, and Its Short- and Long-Term Consequences," in Europe in 1848: Revolution and Reform. Dieter Dowe, ed. (New York: Berghahn Books, 2001): 5.

${ }^{36}$ Dieter Langewiesche, Liberalism in Germany (Princeton: Princeton University Press, 2000): 36.

${ }^{37}$ Heinz and Langewiesche, "The European Revolutions of 1848," 4.

${ }^{38}$ Dieter Langeweische, "Revolution in Germany: Constitutional State, Nation-State, Social Reform," in Europe in 1848: Revolution and Reform. Dieter Dowe, ed. (New York: Berghahn Books, 2001): 135.
} 
governments in the subsequent decades following the revolutions ${ }^{39} \mathrm{He}$ traces such desires to conceptions of Bildung in the nineteenth century that linked knowledge, culture, and philosophy among Germans toward a fulfillment of national cultivation.

An absence of cohesion among revolutionaries in terms of the degree of desired reform, however, consistently impeded solutions to the main subjects debated within the Vorparlament, predominantly whether a republican or monarchical form of government should be adopted under one constitution. Further debates involved the drawing of borders and großdeutsche/kleindeutsche divisions, central to Vick's topic of appeals to a cultural nationalism. Strengthening of partisan groups and irreconcilable differences likewise arose along socioeconomic distinctions among revolutionaries. These factors further generated tension within the Vorparlament and threatened the revolutions as a whole.

The Vorparlament convened in Frankfurt throughout 1848 and into the first half of 1849, remaining solely "dependent on the goodwill of the individual states to implement its policies." 40 Thomas Nipperday and Daniel Nolan describe that such vulnerabilities resulted in "considerable differences of emphasis" among the parties. ${ }^{41}$ From the beginning, the goals of the Vorparlament became ensnared by state interests, such as the reinforcement of their independence through the use of representative government. Should a "Germany" be established, states wanted their autonomy acknowledged. Clearly, a major obstacle to the romantic conception of the nation-state was the lack of popular support for national unity throughout the German Confederation.

\footnotetext{
${ }^{39}$ Brian Vick, Defining Germany: The 1848 Frankfurt Parliamentarians and National Identity (Cambridge: Harvard University Press, 2002): 45.

40 Thomas Nipperday and Daniel Nolan, "The Revolution of 1848-49," in Germany from Napoleon to Bismarck: 1800-1866. (Princeton: Princeton University Press, 1996): 536.

${ }^{41}$ Nipperday and Nolan, "The Revolution of 1848-49," 545.
} 
Embroiled by such existential challenges, a period of inaction within the Vorparlament only provided more time for the formerly stunned monarchies to remobilize. ${ }^{42}$ Encouraged by the rebuffing of the Prussian monarch, non-radical revolutionaries soon turned on one another and abandoned a newly-crafted constitution. Eventually, counter-revolutionary forces repossessed their leadership roles, though not before mass unrest at the state level, as occurred in Saxony and Baden, resisted this shift throughout the winter and spring of 1849. Indeed, it is within this narrowed perspective that the lasting and most important messages of the revolutions become evident. It is therefore through this localized lens, as Sperber argues, that the importance and legacy of the revolutions should be the most heavily examined ${ }^{43}$ Activism on the state level reveals the revolutions' core principles, in particular those goals that the revolutionary refugees would bring to North America.

On the local level, an increase in the press arose from the loss of censorship laws during the earlier period of the revolutions, when monarchs capitulated to much of the revolutionaries' demands out of sheer shock at the speed and ferocity of the impatient protestors. Within the Rhine Province, Sperber points out, thirty-four newspapers began in 1848 alone, compared to the previous higher numbers of one or two published within a single year. ${ }^{44}$ Thus, it could be argued that the vast expansion of the German-speaking press in the United States found deep inspiration and precedent from the increased publications of 1848 in the German Confederation. Notably, as in the United States, the press was embraced by a plethora of political affiliations, including even religious denominations.

The most famous newspaper to come out of this politicized climate was Karl Marx's Neue Rheinische Zeitung, though this example is best worth mentioning due to its slim audience

\footnotetext{
${ }^{42}$ Ibid, 547.

${ }^{43}$ Sperber, The European Revolutions, 3.

${ }^{44}$ Ibid, 160.
} 
demographic--that of leftist civil servants and other educated elites. ${ }^{45}$ In contrast, feminist Mathilde Franziska Anneke - a later friend of Heinzen—released New Cologne News for Townsfolk, Countrypeople, and Soldiers, a rare case in which a woman served as editor. Sperber explains that this newspaper appealed to the masses through a "popular tone...featuring, for instance, the careful explanation of foreign words used in politics." ${ }^{46}$ During this period, even newspapers with little to say regarding the revolutions were published, such as Die Dorfzeitung, that almost solely concentrated on lower-class political and cultural interests. ${ }^{47}$

Sperber also identifies the rise of political clubs, or groups that represented a variety of viewpoints that, by the end of the revolutions in 1849 , almost 1.5 million males had joined across German Central Europe. ${ }^{48}$ There was no question, however, regarding the supremacy of those affiliated with the "Central Association for the Preservation of the Accomplishments of March," the left-wing caucus within the Frankfurt Vorparlament over other major organizations, including significant conservative groups within Prussia. ${ }^{49}$ The radical left benefited from strong linkages and personal connections across wide swathes of territory, united by the moral cause that tied 950 groups and almost half a million people across the region. ${ }^{50}$ In Baden, for example, the year 1848 alone witnessed the formation of approximately 500 societies, composed of 30,000 people altogether. ${ }^{51}$ All participants in the revolutions therefore experienced politicization through the press and public sphere.

The radical phase of the revolutions within German Central Europe is proof that the micro-level has much to offer in correcting perceptions regarding the Revolutions of 1848 as a

\footnotetext{
${ }^{45}$ Ibid, 161.

${ }^{46} \mathrm{Ibid}, 162$.

${ }^{47}$ Ibid.

${ }^{48} \mathrm{Ibid}, 172$.

${ }^{49}$ Ibid, 169.

${ }^{50}$ Ibid.

${ }^{51}$ Lee, "Baden Between Revolutions," 265.
} 
whole. For instance, this approach greatly emphasizes the role of the common actor that realized reform on the ground as representatives bickered in the Vorparlament. By the 1840s, residents of Baden had begun to adopt the identity "Badenese," for themselves, representing popularization of state rather than strictly local ties. Unprecedented numbers of men volunteered for the state military, swearing "loyalty to the new state and to the dynasty." 52 As an example of such sentiment, Mark Traugott tells the story of a people's assembly in Neustadt, "when the speaker began his addresses with the word 'Gentlemen,' his audience correct him by shouting back, 'Citizens!'" 53 In the Baden Revolution, therefore, the revolutionaries did not "propose to dissolve the state" into one Germany; rather, they sought to "make it more equitable and democratic," as well as more inclusive, in order to speed along the state-building process in the name of progressive reform. ${ }^{54}$

This population consisted of workers who had suffered and starved in the last few years, yet even they had their differences. Many Badenese workers advocated modern ideas like universal male suffrage and a ten-hour workday. Others proved more traditional, supporting the continuation of guilds for occupational stability. Some, however, considered these age-old institutions discriminatory and the cause for mass unemployment due to their protectionist attitude and exclusionary practices ${ }^{55}$ Regardless of their dissimilarities, the overarching theme of this phenomenon was that great portions of the Badenese had adopted notions of "citizenship" activism within a structured state apparatus. Indeed, this one unifying factor appeared a real threat when uprisings broke out in the spring of 1848. Mark Hewitson notes that Siegmund von Arnim, then the Prussian envoy to Baden, feared that a charismatic radical leader "could unite

\footnotetext{
${ }^{52}$ Ibid, 266.

${ }^{53}$ Mark Traugott, The Insurgent Barricade. (Berkeley: University of California Press, 2010): 133-134.

${ }^{54}$ Lee, "Baden Between Revolutions," 267.

${ }^{55} \mathrm{Ibid}, 260$.
} 
under his command an army of more than 20,000 desperate and rabid proletarians," a clear indication of the danger that such groups posed to local reigning authorities. ${ }^{56}$

Baden contained within its population an overwhelmingly radical mood that was only intensified by the spring of 1849. Baden and other states' involvement in the Vorparlament sought the establishment of a constitutional, federalist republic, with the combined and crucial guarantee of acknowledgement of states' rights and autonomy. Prussia's Friedrich Wilhelm rejected the proposal to lead such a federal state, and once liberals followed his lead, leftist radicals angrily resisted in a fresh wave of rebellion. ${ }^{57}$ Hewitson describes Baden as the "focus of the campaign for the Reich Constitution," the document which the Prussian monarch had rebuffed. ${ }^{58}$ It was in Baden, therefore, that this "second new revolution" fully erupted. .5 Springtime of 1849 in Baden closely resembled the June Revolution of Paris that occurred a little under a year earlier. People constructed barricades, attacked military arsenals, and cursed the Prussian monarch as "a tyrant and blood-soaked murderer." ${ }^{60}$ When rebellions were crushed in nearby states, revolutionaries poured into Baden's cities, further radicalizing conditions. These were not merely peasant armies. Indeed, Baden's entire military force joined the side of the opposition, refusing to attack their fellow citizens. ${ }^{61}$ Due to this turn of events, Prussian forces worked to destroy regional uprisings for the duration of the summer, a professional behemoth fighting young and disorganized armies. The uprising ended in suppression after a few months, with over 100 insurgents executed for treason, depicting Prussia's most despotic act of the revolutions. Friedrich Wilhelm IV was reported to have

\footnotetext{
${ }^{56}$ Mark Hewitson, The People's Wars: Histories of Violence in the German Lands, 1820-1888. (Oxford: Oxford University Press, 2017): 148.

${ }^{57}$ Sperber, The European Revolutions, 245.

${ }^{58}$ Hewitson, The People's Wars, 178.

${ }^{59}$ Nipperday and Nolan, 564.

${ }^{60}$ Sperber, The European Revolutions, 245.

${ }^{61} \mathrm{Ibid}, 246$.
} 
referred to the Baden revolutionaries as "the filth of all nations," for resisting surrender for so long, writes Hewitson. ${ }^{62}$ Despite this tragic conclusion, success within the revolutions could be measured by its broad and enduring "intellectual ramifications," even if they were not generally acknowledged as such for over a century. ${ }^{63}$

In fact, later German scholars considered the Revolutions of 1848 a failure. The works of Gerhard Ritter, Hans-Ulrich Wehler, Heinrich August Winkler, and Wolfgang Mommsen concluded that "the failure of revolutionaries to entrench a parliamentary system in 1848-9 was symptomatic of the weakness of German political culture." ${ }^{44}$ Especially in the aftermath of the Second World War, the Revolutions of 1848 were observed as the moment in which German Central Europe failed to experience its 1688, 1776, or 1789. Fortunately, scholarship that arose in the 1980s turned such assumptions on their head. David Blackbourn and Geoff Eley's pivotal work in 1983 spoke directly against the Sonderweg thesis so actively espoused by many past scholars of German political and social history who linked the rise of the Third Reich to the missed opportunities of $1848 .{ }^{65}$ Hewitson rejects formerly popular teleological analyses through his goal of situating "the political strivings of revolutionaries in a mid-nineteenth—rather than an early to mid-twentieth century—context." ${ }^{96}$ Refusing the Revolutions of 1848 the right to speak for themselves handicaps a realistic portrayal of their legacy.

Viewing the revolutions as either a failure or success is a misguided method of understanding and drawing conclusions on the legacy of the Revolutions of 1848. Nipperday and

\footnotetext{
${ }^{62}$ Hewitson, The People's Wars, 179.

${ }^{63}$ Mark Hewitson. "'The Old Forms Are Breaking Up, ... Our New Germany Is Rebuilding Itself': Constitutionalism, Nationalism and the Creation of a German Polity during the Revolutions of 1848-49." The English Historical Review 125, no. 516 (2010): 1212.

${ }^{64}$ Hewitson. "'The Old Forms Are Breaking Up, ...," 1177.

65 David Blackbourn and Geoff Eley. The Peculiarities of German History: Bourgeois Society and Politics in Nineteenth-Century Germany (Oxford Oxfordshire: Oxford University Press, 1984): 16.

${ }^{66}$ Hewitson, "'The Old Forms are Breaking Up,...."1178.
} 
Nolan concur that, following the revolutions, "the age then became more civilian" with an increase in popular involvement and state-building. ${ }^{67}$ Certainly, time did not reverse course, for many reforms were either preserved among new state constitutions or created soon after lingering uprisings had been crushed by Prussian forces. Violence may have died down, but important ideas survived elsewhere, within the German lands themselves as well as in the United States. No nation-state of Germany arose, yet for those states whose forces continued fighting in 1849 , such a foundation — still so foreign to the minds of many in the mid-nineteenth centuryhad hardly been the top priority.

Sperber adds to this conclusion, pointing out that the socializing forces that sparked notions of "citizenry" among various populations also led to the downfall of the revolutions. Perhaps the sole prediction of future troubles lay in these unsolved challenges. The so-called "springtime of the peoples" merely connected dissidents to the point of desiring some type of change. Beyond that, "social conflict, nationalist rivalry, interconfessional hostility, and differing...political agendas" split these numbers ${ }^{68}$ No longer the sole subjects of the state, these protestors emphasized by their actions the more important goals of constitutionalism and republicanism. Thus, their progressive priorities contrasted those of the Vorparlament career civil servants, whose desire for a nation-state has consistently dominated the discussion surrounding the political ideas of the Revolutions of 1848 and 1849.

No other revolutionary better represents this massive fissure across the ideological spectrum than does Karl Heinzen, whose tumultuous relationships with conservatives and even fellow radicals represents the failure to compromise as one of the biggest weaknesses of the revolutions in German Central Europe, as well as the diversity of interests within the revolutions

\footnotetext{
${ }^{67}$ Nipperday and Nolan, "The Revolution of 1848-1849," 595.

${ }^{68}$ Sperber, The European Revolutions, 123.
} 
themselves. Yet his perseverance in the wake of the revolutions' end symbolizes their most important and surviving goals transplanted to other shores, in an attempt to reform an existing republic in adherence to those core values espoused in 1848. Most importantly, Heinzen represents those little-known figures who operated in local places and transferred their ideologies to new shores after 1849 .

In the first chapter, Heinzen's youth as well as his inspirations for and evolution toward republicanism in his early years as a writer will be analyzed. Furthermore, the evolution of his radicalization is measured during the years of revolution and his intense involvement in the uprisings. Afterwards, Heinzen's story resumes with his immigration to the United States, followed by an analysis of his subsequent controversies and platforms that he adopts and expands while there. This section of the next chapter ends with his arrival and immediate actions in Louisville, Kentucky which influenced one of the most important documents released by the forty-eighter population in the nineteenth century, the Louisville Platform.

In the second chapter, this groundbreaking document is analyzed alongside contemporary materials published by Heinzen, offering a more nuanced portrayal of the views that were incorporated into the Platform itself. An account of the rise of the Know-Nothing party amidst increased German-immigrant activism follows, as this section depicts rising nativist sentiments in reaction to politicized immigrant communities and their outspoken leaders. In the third chapter, the clash between these two opposing ideologies is made evident in the election-day rights of August 6, 1855, in Louisville, Kentucky. This rapid upheaval reveals the extent of German frustration with voter suppression and other threatened rights as part of a larger continuum of ideas generated from the Revolutions of 1848 and transplanted abroad. 


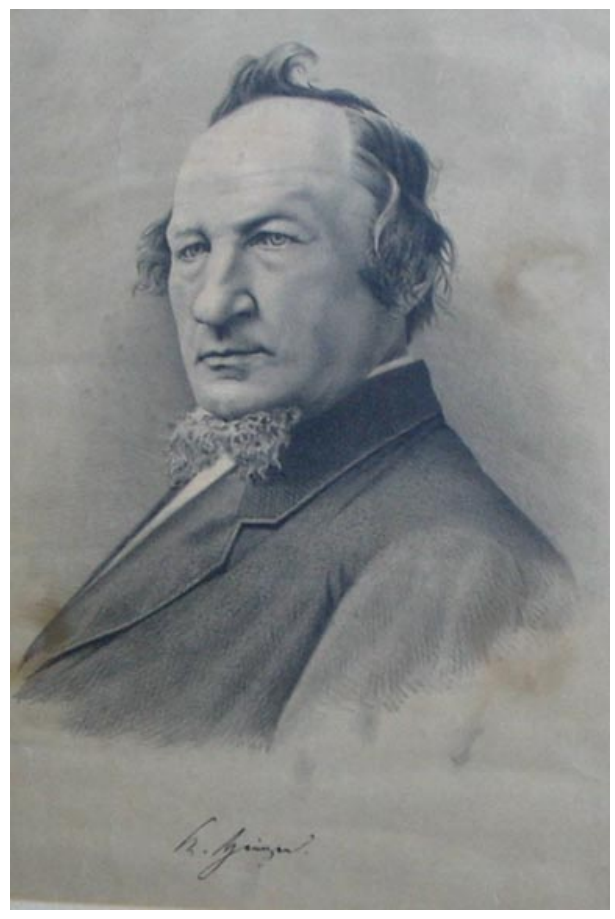

Figure 1: Karl Peter Heinzen. Courtesy Max Kade Institute for German-American Studies, University of WisconsinMadison. 


\section{Chapter I: The Politicization of Karl Heinzen and Arrival in Little Germanies in the U.S.}

Karl Heinzen represents well the republican beliefs espoused by many fellow radicals in the Revolutions of 1848-1849. Indeed, Marie Elizabeth Zakrzewska--contemporary physician, early women's rights advocate, and later friend to Heinzen--described the writer as "the pioneer of republicanism in Germany," and therefore an apt deliverer of this progressive ideology to American shores, specifically to German communities. ${ }^{1}$ As such, it is important to provide an account of Heinzen's life and evolution of beliefs, tracing and identifying pinnacle moments in his maturation that inspired and radicalized his philosophy. The first section of this chapter addresses this task, ending with a thorough analysis of his writings that demonstrate his personal politicization and radicalization.

The second section analyzes German émigré forty-eighters' outreach within Little Germanies across the US and the grassroots' organizations they helped develop, filled and expanded by working-class immigrant activists. Together, these groups fought for the retention of German language, culture, and institutions against demands by the Anglo majority for total assimilation, thus generating the politicization of these communities. Following an exploration of the organizations so important and empowering to German communities, this broad analysis narrows to Karl Heinzen's short-term stay in Louisville, Kentucky, between 1853 and 1854. This peculiar location for a radical forty-eighter was unique due to its geopolitical implications as the largest urban center in the slave state, a factor that influenced Heinzen's and his compatriots activism among Louisville's German community and neighborhoods.

\footnotetext{
${ }^{1}$ Marie Elizabeth Zakrzewska, Marie Elizabeth Zakrzewska: A Memoir. (Boston: New England Hospital for Women and Children, 1903: 16.
} 


\section{The Most "un-Prussian" of Prussian Officials}

Karl Heinzen was a complicated man who made a notable impact on a variety of disciplines. For example, scholars recognized his contributions to Romantic literature and poetry throughout the 1830 s and into the initial years of the $1840 \mathrm{~s}^{2}$ Historian Carl Wittke, in contrast, focused on Karl Heinzen and the forty-eighters as a group, and authored his biography, Against the Current. ${ }^{3}$ Wittke's work dominated scholarship on Heinzen until the 1970s when a new generation of historians explored his influence on tyrannicide thought and early terrorist philosophy. In these studies, Heinzen's most popular composition, Mord und Freiheit, took primary importance. In the late 1970s, Walter Lacquer argued that Karl Heinzen was "the first to provide a full-fledged doctrine of modern terrorism." ${ }^{\prime 4}$ Only through an account of his early years in democratic activism can this extremism be traced throughout Heinzen's life.

Charles Pierre Heinzen was born in Grevenbroich, near Düsseldorf, in 1808, a region conquered by Napoleonic forces and afterwards transformed into the Grand Duchy of Berg. Seven years later, following the French emperor's defeat, Charles Pierre became Karl Heinzen, resident of Prussia's newly-occupied Rhine Province. ${ }^{5}$ In his own youth, Heinzen's father, Joseph, harbored intense indignation at becoming a subject of Prussia. His writings were preserved by Wittke centuries later. Though he never acquired the contemporary fame of his son, Joseph Heinzen espoused early republican ideals, clearly inspired by the French Revolution that

\footnotetext{
${ }^{2}$ For example see Otto Paul Schinnerer, Karl Heinzen: Reformer, Poet, and Literary Critic. Chicago: University of Chicago Press, 1915. Heinzen's literary works are chronicled in a complete list.

${ }^{3}$ Carl Wittke, Against the Current: The Life of Karl Heinzen (1809-1880). (Chicago: University of Chicago Press, 1945). A few years later, Wittke also published a biography on fellow forty-eighter Wilhelm Weitling, equally active in American political and social issues as Heinzen at the time: Carl Wittke, The Utopian Communist: A Biography of Wilhelm Weitling, Nineteenth-Century Reformer. (Baton Rouge: Louisiana State University Press, 1950).

${ }^{4}$ Walter Lacquer, A History of Terrorism (New York: Little, Brown, \& Co., 1977): 26-27 and Martin Miller, "The Intellectual Origins of Modern Terrorism," in Terrorism in Context. Martha Crenshaw, ed. (University Park: Pennsylvania State University Press, 1995): 36.

${ }^{5}$ Wittke, Against the Current, 2.
} 
had reverberated across the borderlands of France and German Central Europe at the time. ${ }^{6}$ In 1797, for instance, the elder Heinzen advocated to his peers that ideas of the French Revolution should not stop short of the Rhine River, and that his native region could serve as the precedent for other German states by creating a republic. ${ }^{7}$

Joseph's son seemed unaware of his father's early years of activism. Historian Carl Friedrich noted that, following his mother's death, the child grew up in a foster home, resulting in little interaction with his father. ${ }^{8}$ Already in his early years, Heinzen proved a contrarian, resisting attempts by his family to serve in the church and later join the priesthood. ${ }^{9}$ The boy was also a perfectionist in that he could not handle criticism of his work. At school, he "blotted out with ink every notation made...by his professors." ${ }^{10}$ Later, in Gymnasium, he constantly complained about the lack of academic and expressive freedom.

Admitted to Bonn University as a medical student, Heinzen got along so poorly with his instructors that they eventually expelled him for insubordination in 1829. Schinnerer later noted, quite incredulously considering Heinzen's later enthusiasm toward violent means for political ends, that the youth "refused to dissect a corpse."11 To spare himself the humiliation of informing his father about his removal from university, Heinzen set off for the colonial capital of Batavia in the Dutch East Indies—present-day Jakarta, Indonesia—as a petty officer. ${ }^{12}$ Heinzen

\footnotetext{
${ }^{6} \mathrm{Ibid}, 3$.

${ }^{7}$ Ibid. For more information regarding the history of Rhineland resistance to Prussian occupation until the Revolutions of 1848-49, see Jonathan Sperber, Rhineland Radicals: The Democratic Movement and the Revolution of 1848-1849 (Princeton: Princeton University Press, 1992).

${ }^{8}$ Friedrich, "The European Background," 170.Heinzen instead considered his father apathetic to politics and, if anything, a sympathizer to the Prussian monarchy. Most of what is known regarding their relationship is based on personal correspondence, in which Joseph Heinzen's son repeatedly begged his father to provide the inheritance owed him by his mother's death. Based on his father's early aspirations for liberty, however, there is no debate as to where the young man inherited his radical spirit.

${ }^{9}$ Ibid.

${ }^{10}$ Wittke, Against the Current, 9.

${ }^{11}$ Schinnerer, Karl Heinzen, 96.

${ }^{12}$ Wittke, Against the Current, 11.
} 
later published an account of his time with the Dutch colonists in 1841, titled Reise eines teutschen Romantikers nach Batavia. He reported that witnessing the harsh treatment of the island's enslaved natives "only strengthened his dislike for all kinds of coercion."13 This experience began his deep contempt and disgust for slavery in all forms that would become especially evident upon his arrival to the United States. Soon after this journey, his conscription into the Prussian military only intensified his aversion to arbitrary state and military authority.

It is difficult to determine which side had the hardest time tolerating the other, Heinzen or his employers within the Prussian state apparatus, during his eight years of employment as a tax collector. Friedrich describes Heinzen as "the most un-Prussian of Prussian officials." ${ }^{14}$ Indeed, Heinzen likened his service for the Prussian government to "an Arabian steed hitched to a manure cart." ${ }^{\prime 15} \mathrm{He}$ was revolted by his superiors' encouragement of spying among fellow colleagues. These Konduitenlisten, or lists describing employee behavior, according to Heinzen, existed only to produce paranoia among state civil servants to encourage demonstrations of unwavering loyalty toward superiors. ${ }^{16}$ The young man's hatred of the Prussian bureaucracy was never so outlandish than when he blamed the corruption around him of causing hemorrhoids. He requested time off for this malady, and when he was subsequently denied leave, Heinzen dramatically announced his resignation through a series of exposés. ${ }^{17}$

Die preußische Bürokratie, in which Heinzen condemned the government for “espionage," was published in $1844 .{ }^{18} \mathrm{He}$ proclaimed the entire Prussian state apparatus a mere servant to tsarist Russia, considered "the greatest enemy of freedom" and emblematic of corrupt

\footnotetext{
${ }^{13}$ Friedrich, "The European Background," 170.

${ }^{14}$ Ibid, 171.

${ }^{15}$ Wittke, Against the Current, 24.

${ }^{16} \mathrm{Ibid}, 25$.

${ }^{17} \mathrm{Ibid}, 26$.

${ }^{18}$ Friedrich, "The European Background," 171.
} 
authoritarianism at the time. ${ }^{19}$ The entire hierarchy of the Prussian military, according to Heinzen, was populated by "subordinate official[s]...completely without any rights," and these civil servants had to "yield blindly to the dark power superiors exert[ed] upon them." ${ }^{20}$ This document contained early signs of Heinzen's radicalization, argue Daniel Bessner and Michael Stauch, that primarily concentrated on autocratic attempts to rob people of their free will. Heinzen circulated copies throughout Prussian cities, intent to "stir spontaneous revolution," but his arrest prevented widespread distribution. ${ }^{21}$

For denouncing the state, Heinzen received a Steckbrief, or court summons, that sparked his first flight to Belgium and later on to Switzerland. ${ }^{22}$ By the mid-1840s, Brussels and the Swiss cantons had become two noted safe havens for political refugees from all across Europe. In this initial period of asylum, Heinzen was introduced to Karl Marx and his circle of fellow ideologues, as well as future companion Ferdinand Freiligrath. Heinzen spent a little under a year in Brussels, and by 1845 tried to establish himself as a journalist in Switzerland. It was during this time in his life that he grew increasingly radicalized, and called for drastic measures to crush the tyrannical Prussian government.

The press played a key role in Heinzen's literary and political career. In the early 1840s, he published reviews for plays as well as composed romantic poems in popular newspapers throughout the Rhineland. He released an entire volume of poems titled Gesammelte Werke around 1841 that made no reference to the Prussian state. By 1842, however, Heinzen released his first satirical piece, Dr. Nebel, oder Gelehrsamkeit und Leben, in which he mocked the "liberal" learned academics who increasingly occupied more government positions in the region.

\footnotetext{
${ }^{19}$ Wittke, Against the Current, 30.

${ }^{20}$ Karl Heinzen, Die preußischebürokratie(Darmstadt, 1845), 167.

${ }^{21}$ Daniel Bessner and Michael Stauch, "Karl Heinzen and the Intellectual Origins of Modern Terror." Terrorism and Political Violence 22: 150. Year of pub, move up to join other lit on terrorism

${ }^{22}$ Wittke, Against the Current, 31-32.
} 
The protagonist of the piece, an active rebel likely modeled on himself, sought to enact progressive change; something that, in Heinzen's opinion, civil servants had failed to accomplish in their positions of authority. ${ }^{23}$ That same year, Heinzen came out with Die kolnische Komodie, in which he proclaimed support for freedom of expression and the important role of Cologne's Karnival as a crucial outlet for Rhinelanders' comedy, art, and satire, to challenge Prussia's censorship laws. ${ }^{24}$

Heinzen's political radicalization soon dominated his interest in literature and poetry. Wittke explains that, as Heinzen himself grew increasingly politicized, the colorful expression of his poems became replaced by underlying anti-Prussian messages. Indeed, Heinzen seemed completely turned off by the romanticism in which he had participated not even a few years before, as is evident in Die Anadyomene des Bodensee, an ode to liberty and republicanism as well as a direct attack on Friedrich Wilhelm IV of Prussia. ${ }^{25}$ A poem written shortly afterward, titled Der polnische Hannibal: am Wasserfall bei Schaffhausen, condemned the earlier partitions of Poland. Heinzen ended this piece with a motivating message to rescue the Poles from the clutches of tsarist Russia. Though these works contained compelling and colorful sentiment regarding the evolution of his political positions, Wittke concludes that Heinzen displayed "little literary merit" at this stage of his career. ${ }^{26}$

Heinzen's literary voice changed along with his strategy to encourage reform in the German Confederation. Frustrations with his life in exile influenced his growing republican world view. As a refugee, Wittke argues, Heinzen was "trying to

\footnotetext{
${ }^{23}$ Carl Wittke, "Karl Heinzen's Literary Ambitions." MonatsheftefürDeutschenUnterricht37, no. 2 (1945): 92.

${ }^{24}$ Wittke, "Karl Heinzen's Literary Ambitions," 93. For more regarding Karnivaland its political ramifications in the Rhine region, see James M. Brophy, "Carnival and Citizenship: The Politics of Carnival Culture in the Prussian Rhineland, 1823-1848." Journal of Social History 30, no. 4 (1997): 873-904.

${ }^{25} \mathrm{Ibid}, 90$.

${ }^{26}$ Ibid.
} 
salvage...honor...independence...and self-respect.”27 Thus, he only grew more hostile toward Prussia, which had forced him to flee abroad. Prior to Heinzen's radicalization, it is important to note that he was politically moderate in his younger years, and indeed shared solutions for reform with more conservative liberals at the time. In Die Opposition, written during his period as a refugee in Switzerland, Heinzen rejected the use of violence in order to crush Prussian hegemony. Instead, he predicted that progressive change would emerge as people became "enlightened." The more educated the masses, the more likely reforms would develop across German Central Europe and the continent. ${ }^{28}$

Over time, Heinzen's patience in regard to such a peaceful process grew incredibly thin, as did his faith in common people and evolutionary change. Sometime in 1845 , he was notified of his six-month prison sentence issued by a Cologne court as punishment for Die preussische Bürokratie. ${ }^{29}$ By the time of his publication of Die Teutsche Revolution in 1847-his follow-up project to Die Opposition, Heinzen had embraced a bloodier program for reform. In this pamphlet, he supported actions of tyrannicide, proclaiming that "only revolution" could strip these rulers of their thrones. ${ }^{30}$ This radical pronouncement left for him only the Swiss canton of Geneva as a possible place of residence. His publication of another newspaper, Der Deutsche Tribun, resulted in his banishment from Switzerland indefinitely as he encouraged the strategy of tyrannicide, revolution, and interventions by foreign and democratic powers to enact reform in the German Confederation. ${ }^{31}$

An analysis of Heinzen's literary and political writings during the 1840s reveals his growing politicization and embrace of republican principles. His experience in Batavia as a

\footnotetext{
${ }^{27}$ Wittke, Against the Current, 35.

${ }^{28}$ Friedrich, "The European Background," 172.

${ }^{29}$ Wittke, Against the Current, 32.

${ }^{30}$ Friedrich, "The European Background," 172.

${ }^{31}$ Wittke, Against the Current, 37.
} 
witness to the degradation of slavery drew him to a commitment for human rights to defend the vulnerable against arbitrary domination. His general opposition to oppressive power structures took on a specific form as he worked for the Prussian state only to denounce it as corrupt and criminal. His anti-monarchical views strengthened over time as the Prussian state sought to hold him accountable for his numerous offenses. His comparison of Prussia with Russia is telling, as many liberals at this time viewed Russia as the most draconian and authoritarian regime in Europe. Flight from the German Confederation fed his hostility to Prussia, in particular its despotic leadership, unethical bureaucracy, and policy of censorship. By the late 1840s, Heinzen's opposition to the monarchical state and military as well as support for human rights and freedom of expression placed him squarely within the republican worldview. After he began to advocate violence to facilitate an overthrow of the monarchy and advance political reform, his republican views had clearly radicalized.

By the end of 1847, Heinzen's finances suffered considerably due to exile and unemployment. In desperate need of funds, he did what many other political refugees resorted to at the time and migrated to the United States in the hopes of alleviating these financial woes through lecture tours and editing jobs. ${ }^{32}$ He first arrived in New York City on the Missouri from the port of Havre, listing himself as a "writer." 33 Through public speeches and his position at New York City's Deutsche Schnellpost, Heinzen transformed into one of the many refugee celebrities among local German communities. Heinzen like most of the other political refugeeswhether in Brussels, the Swiss cantons, London or the US - resided in attics above shops, their printing offices, or boarded together in apartments. Theirs was not a lifestyle of comfort; rather, they had much in common with the average immigrant who primarily left their homeland for

\footnotetext{
${ }^{32}$ Friedrich, "The European Background," 173.

${ }^{33}$ Germans to America: Series II, vol. 5, July 1847-March 1848. Ira A. Glazier, ed. (Wilmington: Scholarly Resources, Inc., 2003): 266.
} 
economic improvement. Heinzen's complicated relationship with money would never end.

Throughout his time in asylum, he and his family constantly suffered from depleted finances and a wall of debts.

In early 1848 , this period of suffering for political reform finally appeared worthwhile, as the revolution had erupted in France and the German Confederation bidding Heinzen to return and contribute to the cause through his activism. Heinzen's disappointment with the course of the revolution is made clear exactly one year later, however, when he concluded that only foreign intervention, namely by the French, could save the cause on the part of the Baden revolutionaries. There is evidence that he had already lost faith in the Frankfurt representatives following his defeat in the Hamburg elections for a seat in the Vorparlament, which were held shortly after his return to the German Confederation on March 30, 1848. ${ }^{34} \mathrm{He}$ did, however, earn twelve thousand votes--not a dismal loss. ${ }^{35}$ Heinzen disagreed with the liberal majority in the Vorparlament based on their willingness to cooperate with the crowns of German Central Europe and contemplate a constitutional monarchy. In contrast, he made his position clear in the 1848 pamphlet, Deutschland Eine Republik, in which he insisted that the main question of the day is whether "Germany" would be a monarchy or republic. He denounced the rule of kings and princes across Europe and argued that the future of Germans depended on their liberation from their political past as he called them to rally under the flags of republicanism. ${ }^{36}$

Heinzen subsequently moved to Baden, befriending another committed republican Friedrich Hecker, a representative of the Vorparlament who walked out on it when the majority of liberal representatives agreed to cooperate with German princes. With Heinzen, Gustav Struve and other radical republicans and democrats, he attempted to overthrow the Duchy of Baden in

\footnotetext{
${ }^{34}$ Daniel Bessner and Michael Stauch, "Karl Heinzen and the Intellectual Origins of Modern Terror," 151.

${ }^{35}$ Wittke, Against the Current, 64.

${ }^{36}$ Karl Heinzen, 1809-1880. Deutsche Eine Republik. Belle-Vue: [J. Kohn,], 1848. P 1-3.
} 
the name of the people and establish the Republic of Baden. ${ }^{37}$ For a few months, the partnership between Hecker and Heinzen prepared Baden for its final stand in 1849, involving at one point Heinzen as head of an army. Yet Heinzen remained unimpressed by Hecker's forces of untrained artisans, students, and farmers. The Badenese, he believed, were in desperate need of stronger international allies.

Without Hecker's permission, he submitted an article to the Baseler National-Zeitung, advocating for French and Swiss intervention on behalf of the Baden insurgents. ${ }^{38}$ When Hecker prevented this piece from publication, Heinzen and his companion, Gustav Struve, moved across the French border to Strasbourg to garner support for their cause. They referred to their group of radicals as the "Committee for the Further Propagation of the Revolution," attempting to do so through internationalizing Hecker's putsch in Baden. ${ }^{39}$ Hecker, once more, objected to these proclamations on the basis that it would be considered treason in the eyes of the Prussian state. ${ }^{40}$ While in Strasbourg, however, Heinzen and Struve released Die Schilderhebung Der Deutschen Republikaner Im April 1848, which denounced the Vorparlament representatives as fully incompetent and praised Baden's residents for their noble fight to acquire further rights and liberties. ${ }^{41}$

Heinzen presented the Badenese as providing Germans the right example of how the Revolution in the German Confederation should proceed. In Die Schilderhebung Der Deutschen Republikaner Im April 1848, he wrote that the citizens understood the goals of the revolution and articulated them through a series of town meetings. They demanded sweeping improvements in

\footnotetext{
${ }^{37}$ Bessner and Stauch, "Karl Heinzen," 151.

${ }^{38}$ Wittke, Against the Current, 66.

${ }^{39}$ Bessner and Stauch, "Karl Heinzen," 151.

${ }^{40}$ Wittke, Against the Current, 67.

${ }^{41}$ Karl Heinzen, and G Struve. Die Schilderhebung Der Deutschen Republikaner Im April 1848. Strassburg: Schmidt und Grucker, 1848, 5.
} 
the state, in particular in relation to trade, agricultural and commercial conditions. They called for prosperity, education and freedom for all without regard for their birth, social status or religion. Finally, they recognized that these improvements would not take place if the dynastic government remained in power. One can easily see Heinzen's own political world view reflected in his praise of the Badenese people. He also noted that they asked the right questions during the revolution, did the people of Baden want a monarchy or a republic. ${ }^{42}$ Their program which Heinzen supported represented the extent that republican views had grown by this time. He also compared the confidence of the people of Baden to that of the ineptitude and confusion of the politicians in the Frankfurt Parliament. ${ }^{43}$ Party loyalties and their apparent willingness to cooperate with aristocratic interests, in Heinzen's mind, would never prove strong enough to ensure the democratic desires of the people for a better life. Nor did he view the defeat of Hecker as a defeat for republicanism, the future Republic was "not defeated through this, rather it is first arisen," and impossible to stamp out completely from the hearts and minds of the people. ${ }^{44}$ Despite their call to action, the French rejected the radicals' invitation to intervene on their behalf.

Heinzen continued his revolutionary commitment in Geneva, where he stayed until the spring of 1849. He partnered for a time with another committed republican Giuseppe Mazzini to "raise a German-Italian legion." 45 This project failed to accelerate, however, as Austrian counterrevolutionary victories in the Lombardy forced Mazzini to flee to England and discouraged Heinzen from relocating there. Heinzen's commitment to republicanism drew him to international cooperation with like-minded radicals across Europe. In Geneva, Heinzen published

\footnotetext{
${ }^{42}$ Heinzen and Struve, 5-6.

${ }^{43} \mathrm{Ibid}, 5$.

${ }^{44}$ Ibid, 11.

${ }^{45}$ Wittke, Against the Current, 69.
} 
another work that made clear distinctions between republicanism and communism. He felt it necessary to differentiate himself from communism and its adherents, condemning their ideology as misguided. To be sure, Heinzen's beliefs in part complemented some elements of communism. For example, in a short biography of Heinzen published in 1888 , he explained that though he was not a communist, he expected the state to treat all people with the same social rights. ${ }^{46}$ In Die Helden des deutschen Kommunismus, published in 1848, however, Heinzen argued that Karl Marx and Friedrich Engels concentrated "too intently on the bourgeois accumulation of capital while ignoring those who truly hold power, the aristocracy." ${ }^{\prime 77}$ Rather than attack the capitalists, they should acknowledge that monarchies that thrived on market success as the true obstacles to social and economic progress. Following the revolutions' end, Heinzen's reputation among socialists would sour due to such criticisms.

Heinzen produced another newspaper in Switzerland, Die Evolution, in which he called for European refugees, believers in liberty, and workers to combine under one united front and "make all Europe safe for democracy" through force..$^{48}$ The re-establishment of Poland, the crushing of Russia's influence, and the destruction of monarchies were just a few points put forward. ${ }^{49}$ Heinzen also supervised the composition of propaganda for regional radical newspapers. Yet he vacated his post following censures and criticism of his most offensive pieces by the same revolutionaries who had earlier fought against censorship..$^{50}$

\footnotetext{
${ }^{46}$ H.J. Ruetenik and Harold Jantz Collection. Berühmte Deutsch Vorkämpfer für Fortschritt, Freiheit und, Friede in Nordamerika: Von 1626 bis 1888. (Cleveland: Forest City Bookbinding Co., 1888): 276-277.

${ }^{47}$ Karl Heinzen, Die Helden des deutschen Kommunismus (Bern, 1848). Karl Marx responded to this criticism in "Moralizing Criticism and Critical Morality: A Polemic Against Karl Heinzen,"' in Selected Essays by Karl Marx, 1926, reprinted by BiblioLife in 2008.

${ }^{48}$ Wittke, Against the Current, 71.

${ }^{49}$ Ibid.

${ }^{50} \mathrm{Ibid}, 73$.
} 
In Die Evolution, the most extreme elements of Heinzen's ideology were finally exposed as he designated "tyrannicide as the chief means of progress." ${ }^{51} \mathrm{He}$ advocated war and the escalation of violence as the only method to enact significant change. After all, the systematic strategy utilized by the Vorparlament had completely failed in his perspective. Why was it, he inquired, that only revolutionaries were sacrificed in these conflicts? Could not the blood of those monarchs who prevented progress be shed to ensure its fulfillment? Advances in technology and science, through explosive weaponry and other potentially violent inventions, he believed, would improve the capacity to implement change. ${ }^{52}$

For these increasingly violent views, the radical received the nickname "Bloody Heinzen. ${ }^{" 53}$ By this time, Swiss officials so enthusiastically desired his departure that Heinzen's trip out of Europe was largely funded by their government. He first migrated to London, as did many other banished forty-eighters, in September of 1849. There, Heinzen published Lehren der Revolution in the Deutsche Londoner Zeitung. He did not hold back on his resentment toward the moderates and liberals who had betrayed the cause of the Republic and its progressive constitution. In the next wave of uprisings, he predicted that the price for progress would involve the loss of "a few million heads." ${ }^{4}$ Bessner and Stauch claim that these series of letters "exhibited some of the ferocious language that characterizes Mord und Freiheit," released not long after Heinzen's stay in London. ${ }^{55}$ Heinzen's decline in popularity by this time amongst fellow radicals was attributed to their protest of such a dangerous publication. Engels eventually managed to guarantee Heinzen's departure from England, writing in the Northern Star that

\footnotetext{
${ }^{51}$ Ibid.

${ }^{52} \mathrm{Ibid}, 74$.

${ }^{53}$ Friedrich, "The European Background," 173.

${ }^{54}$ Wittke, Against the Current, 79.

${ }^{55}$ Bessner and Stauch, "Karl Heinzen," 151.
} 
Heinzen was no longer welcome within the group of German exiles. ${ }^{56}$ Nevertheless, in Erlebtes, a later account of his experiences in the Revolutions of 1848, Heinzen reiterated his belief that the downfall of the revolutions had been due to the stupidity and treason of these so-called "revolutionaries." ${ }^{77}$ Within two years, Heinzen had completely broken with his fellow revolutionaries.

In late 1850, Heinzen and his family migrated back to New York City. Between that time and 1853, he composed Mord und Freiheit, his most well-known and polemical work. As he never retracted statements made within its pages, it is important to provide a brief analysis regarding its themes of tyrannicide and terrorism. Heinzen confronted other revolutionaries for acts of cowardice during 1848 and 1849, declaring that "whatever is right should be proclaimed openly, before all the world, so that it may be done as a right." ${ }^{\text {5 }}$ What were these justified actions? They included any gesture from voicing one's disdain toward authoritarian regimes to assisting in that regime's violent end. According to Heinzen, these ultimate acts could only be achieved through murder. Such exhibitions of terror sprouted seeds of liberation. It was thus in Heinzen's mind the responsibility of "humanity...[to] become the murderess of murderers." 59

Benjamin Grob-Fitzgibbon points out that Heinzen did not only desire to see the downfall of noble tyrants. Rather, he wished "the entire system," which he viewed as corrupt and selfserving, eradicated along with their monarchs. ${ }^{60}$ In this message, it is not difficult to notice the themes of Die preußische Bürokratie reverberating once more in Heinzen's writings. Following the disappointing results of revolutions, the primary difference was the ferocity inherent within

\footnotetext{
${ }^{56}$ Walter Lacquer, "Karl Heinzen and the Origins of Modern Terror," in The Political Psychology of Appeasement: Finlandization and Other Unpopular Essays. (New Brunswick \& London: Transaction Publishers, 1980): 92.

${ }^{57}$ Karl Heinzen, Erlebtes, (Boston: Selbstverlag des verfassers), Volumes 1 and 2, 1864-1874, 503.

${ }^{58}$ Karl Heinzen, Mord und Freiheit, (Indianapolis: H. Lieber, 1881): 23.

${ }^{59}$ Heinzen, Mord und Freiheit, 1-2.

${ }^{60}$ Benjamin Grob-Fitzgibbon, "From the Dagger to the Bomb: Karl Heinzen and the Evolution of Political Terror," Terrorism and Political Violence 16, no. 1 (2004): 104.
} 
such statements and the expansion of the enemy to be defeated. The "enemy," took the form of any civilian who worked under or submitted themselves to the rule of autocrats. It is no wonder that liberals and communists dissociated from Heinzen's violent solutions to achieve liberty, as he viewed anyone of all classes who did not take an active stance against authoritarian rule as equal threats to liberation, thus likening them to the monarchs in power. ${ }^{61} \mathrm{He}$ denounced corrupt monarchies and the passivity of citizens who supported it.

Bessner and Stauch emphasize that Heinzen considered terrorist acts "a tool of a mass of people, not necessarily linked to any nation." 62 The internationalism behind this revolutionary activity reveals that Heinzen looked "beyond the borders of Germany" and by doing so "posit[ed] terrorism as a transnational phenomenon." ${ }^{33}$ Indeed, the ostracized and penniless immigrant transported this wide array of extreme ideas back with him to the United States, a location in which they flourished in some neighborhoods and were spurned in others.

Heinzen's final country of residence contained many career options as well as a range of new challenges and opponents to confront. Yet he never forgot the lessons of his past revolutionary experiences. In a pamphlet that criticized the unification of Germany under Prussian rule in 1871, Heinzen explained that "the success of...remodeling [the body politic]...depends on two conditions--first, in the establishment of correct principles for the future, and, secondly, in the annihilation of the destructive elements of the past."64 Even in 1871, Heinzen stressed the necessity of violence toward achieving reform, alluding to what he considered the most significant mistake of the revolutionaries. In hindsight, Heinzen believed that the violence of 1793 was necessary for success in 1848, and asserted that "it is exactly the

\footnotetext{
${ }^{61}$ Grob-Fitzgibbon, "From the Dagger to the Bomb," 109.

${ }^{62}$ Bessner and Stauch, "Karl Heinzen," 146.

${ }^{63}$ Ibid.

${ }^{64}$ Karl Heinzen, "What is Real Democracy? Answered by an Exposition of the Constitution of the United States," 1871, 13.
} 
neglect of these conditions which generally defeat[ed] these attempts at reformation." ${ }^{95}$ Though Heinzen's politics radicalized prior to 1848 , the unfulfilled revolutions clearly sharpened his political worldview as well as his commitment to republicanism and reform that he demonstrated in the United States.

\section{$\underline{\text { Anchored in Community }}$}

This chapter now turns to the world in which Heinzen arrived after 1850, in particular the German-speaking localities that revolutionary exiles worked and resided within upon their arrival in the US. Heinzen, like other forty-eighters, utilized his own talents for writing and public speaking in partnership with local groups, whether they were political in nature or culturally-oriented. Heinzen did not create most of these organizations; they predated his arrival. Heinzen's presence, politicization, and persistence to push for reforms and active citizenship, however, ignited a passion in many of these groups to defend their beliefs and rights against an anti-immigrant party establishment that had begun to dominate politics nationwide.

Between 1840 and 1900, almost five million Germans of all backgrounds migrated to the United States. ${ }^{66}$ The years 1845 to 1859 alone counted for 1,261,000 German immigrants, with the period 1850 to 1854 - in the immediate aftermath of the revolutions - including over 650,000 of that total. ${ }^{67}$ They settled and built an immigrant community that Hartmut Keil states could "no longer" be treated as a "negligible entity." ${ }^{68}$ A portion of the forty-eighters, Heinzen among them, quickly acclimated themselves within existing German enclaves, taking over editing

\footnotetext{
${ }^{65}$ Heinzen, "What is Real Democracy?" 13.

${ }^{66}$ Germans to America: Series II, vol. 5, July 1847-March 1848. Ira A. Glazier, ed. (Wilmington: Scholarly Resources, Inc., 2003): vii.

${ }^{67}$ Germans in America, ix.

${ }^{68}$ Hartmut Keil, "Alexander von Humboldt, the German Immigrant Community, and Antebellum Politics." Przeglogon ad polonijny31, no. 4 (2005): 13.
} 
positions and publishing new political papers to satisfy their audience, already politicized by the breakout of the Revolutions of 1848 and 1849. Within these "Little Germanies," Ernest Bruncken explains that a majority of radicals "ceased to long for a renewal of revolutionary movements in Europe" as they soon recognized demand for reform in terms of treatment of immigrants, labor concerns, as well as geographic and political fissures over slavery. ${ }^{69}$

Daniel Nagel remarks that even the significant number of political refugees moving to the United States at this time paled in comparison to overall German immigration rates. Certainly, not all these immigrants departed their homeland solely for political reasons. Rather, most simply "sought a better standard of living." ${ }^{\text {" } 00}$ A significant portion of this population, however, consisted of male artisanal workers who, according to Bruce Levine, played an undervalued role within the revolutions that had raged across Europe..$^{71} \mathrm{~A}$ rising industrial economy and the use of unskilled labor threatened institutions like the guilds that had protected their skilled status for centuries. ${ }^{72}$ They understood emerging industrial capitalism as a threat to their control over local trades. Thus, their ranks had joined the throngs of supporters in the streets of Baden who fought in part to preserve these craft organizations. Keil explains that due to their politicization prior to emigrating from German Central Europe, these workers merely transferred concerns regarding industrialization and the emergence of factory work from the German lands to North America. ${ }^{73}$

\footnotetext{
${ }^{69}$ Ernest Bruncken, "German Political Refugees in the United States, 1815-1860," in The German-American FortyEighters, 1848-1998. Don Heinrich Tolzmann, ed. (Indianapolis: Indiana University Press, 1998): 9.

70 Daniel Nagel, "The German Forty-Eighters' Critique of the U.S. South," in The South and Europe: Transatlantic Relations in the Nineteenth and Twentieth Centuries. Cornelius A. Van Minnen and Manfred Berg, eds. (Lexington: University of Kentucky Press, 2013): 52.

${ }^{71}$ Bruce Levine, "Free Soil, Free Labor, and Freimanner: German Chicago in the Civil War Era," in German Workers in Industrial Chicago, 1850-1910: A Comparative Perspective. Hartmut Keil and John B, Jentz, eds. (DeKalb, Ill: Northern Illinois University Press, 1983): 166.

72 Levine, "Free Soil, Free Labor, and Freimanner, 166.

${ }^{73}$ Hartmut Keil, "German Socialist Emigrants to the United States in the Second Half of the Nineteenth Century," in Transatlantic Cultural Contexts: Essays in Honor of Eberhard Brüning. Hartmut Keil, ed. (Tübinge: Stauffenburg Verlag Brigitte Narr GmbH, 2005): 190.
} 
In the late nineteenth century, Thomas Stockham Baker asserted that German visions of their destined role in the United States included progressive reforms. He claimed that "nearly all immigrants believed firmly that the Germans had a mission to fulfill" and sought to do so in a "political way." 74 Thus, popular calls for state reform, improvement in trade and agriculture, and rights for all heard in Baden in 1848 could echo as they were transplanted to another place through German immigration. Similar to their more notable forty-eighter counterparts, regular immigrants continued the fight against "proletarianization and pauperism" within labor unions formed upon their arrival and settlement throughout countless cities of varying size in the United States. ${ }^{75}$ In addition, these immigrant workers occupied a "social base" within communities, serving multiple roles through the creation of craft unions, community clubs, and cultural societies. ${ }^{76}$ Indeed, of all German-Americans, immigrant workers and artisans most prominently supported and took part in the realization of new goals of total democracy, expanding rights and workers' empowerment espoused by forty-eighter leaders within their neighborhoods. ${ }^{77}$

Christiane Harzig and Dirk Hoerder identify the intent by some immigrants to create or join labor and social groups upon arrival in their new country, as they hoped "to improve in a collective manner unsatisfactory conditions" within their communities. ${ }^{78}$ These efforts involved improvements in the workplace and home environments. Likewise, Dieter Langewiesche adds that through forming such organizations these migrants arrived in the United States "with cultural practices and...goals for life projects that they could not realize at home." ${ }^{\prime 29}$ These desires

\footnotetext{
74 Thomas Stockham Baker. Young Germany in America.(Philadelphia: P.C. Stockhausen, 1897): 78.

${ }^{75}$ Levine, Free Soil, Free Labor, and Freimanner,"166.

${ }^{76}$ Ibid.

${ }^{77}$ Bruncken, "German Political Refugees," 44.

${ }^{78}$ Christiane Harzig and Dirk Hoerder, What is Migration History?(Cambridge: Polity Press, 2009): 93.

${ }^{79}$ Dieter Langewiesche, "Revolution in Germany: Constitutional State, Nation State, and Social Reform," in Europe in 1848: Revolution and Reform. Dieter Dowe, ed. (New York: Berghahn Books, 2001): 258.
} 
were shared among all forty-eighters, whether they were noteworthy editors like Heinzen or working-class craftsmen of vague origins.

Over seventy-five percent of German immigrants resided in nine urban areas across the east and midwestern United States in $1860 .{ }^{80}$ An entry in Angela and Nikolaus Heck's diary speaks to their happiness living in a German-speaking neighborhood in New York City. They described their surroundings "among nothing but good people who are all Catholic and German" as enviable even to the wealthiest German back home, as in their working-class community, there existed strong support and familial relations between neighbors. ${ }^{81}$ Indeed, many Germans sang similar praises in describing the "Little Germanies" in which they had settled. Most enjoyed the comforts of shared cultural life so much that calls to conform to Anglo-American ways of life went largely ignored, such as one plea by a German pastor that encouraged abandoning their native tongue for the English language..$^{82}$

Hartmut Keil argues that within these ethnic neighborhoods, shared experience in work, communal life, and traditional customs formed a common identity that had not existed among German speakers prior to their arrival. This empowerment was especially critical when settling into a new country as a noticeable minority group. Expanding Levine's argument, he explains that "an immigrant community sharing common class and ethnic experiences on the basis of work, home, and leisure" strengthened their fight against challenges relating to an "often hostile society" as it provided "help and guidance in their everyday needs." ${ }^{83}$ German immigrants

\footnotetext{
${ }^{80}$ Levine, The Spirit of $1848,58$.

81 Walter D. Kamphoefner, Wolfgang Helbich, and Ulrike Sommer, eds. "Angela and Nikolaus Heck, 'New York City, July 1, 1854," in News from the Land of Freedom: German Immigrants Write Home. (Ithaca: Cornell University Press, 1988): 373.

82 Pastor Bogan, "Instruction for German Immigrants, 1850," in America's Immigrants: Adventures in Eyewitness History. Rhoda Hoff, ed. (New York: Henry Z. Walch, Inc., 1967): 63.

${ }^{83}$ Hartmut Keil, German Workers' Culture in the United States, 1850-1920. (Washington, D.C.,: Smithsonian Institution Press, 1988): xvii.
} 
wished to improve the conditions in which they lived and worked. Much of the support and efforts to do so arose out of those communities themselves, and there was indeed much economic and social improvement to be made in the 1840s and 1850s in the US.

Levine explores how the "bonds of ethnic unity," strengthened by the enthusiastic and excited response to the Revolutions of 1848 , continued to develop despite the challenges that confronted immigrants upon their arrival. ${ }^{84}$ Many craftworkers and laborers quickly grew dissatisfied with their working-class status. "Unprepared for the bleak, hard-driven" and monotonous work, some immigrants spoke out against such working and living conditions..$^{85} \mathrm{~A}$ German shoemaker in New York City told a crowd in 1855 that "in America, we are free, but not free enough.....We want," he summarized, "the liberty of living."

Other individuals spoke on their struggles acclimating to American industrial work, ranging from language barriers to financial difficulties. In 1855, Martin Weitz of Rockville, Maryland, lamented his inability to acquire a job, writing that "if I had been able to speak English, I could've gotten a job, but I can't." ${ }^{97} \mathrm{He}$ also emphasized an obstacle facing many immigrants at the time, that of virtually paying to have a job: "I had to pay ten dollars training fee. Every newcomer who comes here has to pay." ${ }^{88}$ That same year, Nikolaus Schwenck of Chicago wrote home about his mundane job making copper pipes for trains. He spoke of the immigrant community in which he lived, describing that "some are much more wretched here

\footnotetext{
${ }^{84}$ Levine, "The Migration of Ideology," 10.

${ }^{85} \mathrm{Ibid}, 11$.

${ }^{86} \mathrm{Ibid}, 12$.

${ }^{87}$ Walter D. Kamphoefner, Wolfgang Helbich, and Ulrike Sommer, eds. "Martin Weitz, 'Rockville, July 29, 1855," in News from the Land of Freedom: German Immigrants Write Home. (Ithaca: Cornell University Press, 1988): 342.

88“"Martin Weitz, ‘Rockville, July 29, 1855,” 342.
} 
than in Germany." 89 To survive in such an environment, German workers depended on their neighborhoods for mental and emotional support through linguistic, ethnic, blood-related, and constructed kinship groups.${ }^{90}$ Through many types of assistance offered by their communities, fellow Germans adjusted to their new lives in a foreign land by preserving "familiar habits." ${ }^{11}$ As increasing numbers of forty-eighters and craftworkers arrived, systemic weaknesses inherent in their work and neighborhoods were increasingly confronted through social and political outreach, producing a more politicized and combative population rooted in a shared linguistic and cultural identity.

Keil argues that "there was hardly a German association or club...that was not firmly anchored in a neighborhood." 92 These associations provided community social activities and leisure opportunities to enrich and empower their neighborhoods with cultural expressions and practices. It is evident that labor patterns posed a direct influence on social activities, as Sunday was the only day that men did not work, thus the orientation of labor remained intimately intertwined with elements of community culture. Sunday, for example, was a day of entertainment and leisurely activity, that included afternoon shopping, picnicking, and drinking. In Chicago, for example, the one theater that remained open on Sundays was the Deutsches Haus and its associated German Men's Singing Society developed a wide following among Chicagoans of all demographics in the early $1850 \mathrm{~s} .{ }^{93}$

\footnotetext{
${ }^{89}$ Hartmut Keil and John B. Jentz, eds. "Nikolaus Schwenck, 'Chicago, September 9, 1855," in German Workers in Chicago: A Documentary History of Working-Class Culture from 1850 to World War I. (Urbana: University of Illinois Press, 1988): 25.

${ }^{90}$ Hartmut Keil, "German Immigrant Workers in Nineteenth-Century America: Working Class Culture and Everyday Life in an Urban Industrial Setting," in America and the Germans, Volume I: An Assessment of a ThreeHundred Year History." Frank Trommler and Joseph McVeigh, eds. (Philadelphia: University of Pennsylvania Press, 1985): 200 and Simone Wegge, "Network strategies of nineteenth century Hesse-Cassel emigrants," History of the Family, (2008) 13/3, 296-314.

${ }^{91}$ Keil, "German Immigrant Workers," 200.

${ }^{92}$ Keil, German Workers' Culture, 39.

${ }^{93}$ Keil, "German Immigrant Workers," 182.
} 
Günter Moltmann identifies a prevalence of German clubs and organizations forming in the nineteenth century. These groups, which included aid societies, insurance providers, boarding houses, singing troupes, Lokals (bars), theatres, fire squads, and fitness clubs like the Turnverein, provided assistance for those who had just arrived, without jobs and family. ${ }^{94}$ Martin Weitz celebrated the cultural renaissance within his small German enclave in Rockville, commenting that "with the singing clubs and music, there the Germans in America are on the rise, they earn a lot of respect for that. Even we in Rockville, we have two singing clubs. With our German singing we earn great respect." 95 The presence and prominence of these social organizations heightened German-immigrant confidence.

Though almost all social organizations and aid suppliers worked solely within a certain community, Agnes Bretting posits the German Society as an example of nation-wide financial assistance toward a specific immigrant minority. Based in New York City and formed in 1854, the German Society assisted new immigrants with acquiring jobs and housing. ${ }^{96}$ Expressing the importance of such an organization, one of the Society's officers explained that "the German immigrant...if he requires assistance," would only seek help "at the place where his native language is spoken."97 The German Society "demanded protection of the immigrants" upon their disembarkation. ${ }^{98}$ To ensure their accommodation, this representative requested aid from New York congressmen to further support the population of German immigrants within the city.

\footnotetext{
94 Günter Moltmann, "The Pattern of German Emigration to the United States in the Nineteenth Century," in America and the Germans, Volume 1: An Assessment of a Three-Hundred Year History. Frank Trommler and Joseph McVeigh, eds. (Philadelphia: University of Pennsylvania Press, 1985): 22.

95“Martin Weitz, 'Rockville, July 29, 1855,” 346.

${ }^{96}$ Keil, German Workers' Culture, 39.

${ }^{97}$ Feldstein and Costello, comps. "Memorial of the Officers of the German Society of the City of New York to the New York Legislature, Demanding a Share of the Head Tax Receipts," Assembly Democrat 165, $1848,3$.

98 Agnes Bretting, "Organizing German Immigration: The Role of State Authorities in Germany and the United States," in America and the Germans, Volume 1: An Assessment of a Three-Hundred Year History. Frank Trommler and Joseph McVeigh, eds. (Philadelphia: University of Pennsylvania Press, 1985): 34.
} 
Though many worker associations addressed problems beyond labor, German workers viewed poor wages and job security as permanently intertwined with all other concerns plaguing their community, comprising housing, cultural initiatives, education, and their neighborhood's moral economy. Indeed, London's Chambers' Edinburgh Journal observed and lamented that, through these unions, Germans "carry out with them all the passions, prejudices, and dispositions of the fatherland, and keep them immovably." 99 As in their homeland, craftsmen continued their fight against proletarianization and impoverishment by forming trade unions.

There existed several types of labor unions within the German community. Levine identifies Geschäftsvereine and Protekivunionenas those focused on a particular craft. The more inclusive Arbeitervereine composed of workers from a variety of backgrounds, skilled and unskilled. ${ }^{100}$ Generally, these associations provided insurance for workers, although they never forgot that leisurely activity was crucial to their standard of living. For this reason, they protested sabbatarian and temperance laws. ${ }^{101}$ At one point, many working-class immigrant labor unions even accused the German Society of being "pro-business" by recruiting vulnerable German newcomers into dismally-paid and insecure jobs. ${ }^{102}$ Kathleen Conzen highlights one example in 1848 of German workers in Milwaukee protesting their employer's dismissive views of their labor when he remarked that "he can get along well without us" and decreased their pay as he saw fit. ${ }^{103}$ They insisted that their rights as citizens be acknowledged by their boss, explaining that "although most of us are German, we are nevertheless free and have no wish to be simply

\footnotetext{
${ }^{99}$ Feldstein and Costello, comps. "German Emigration," Chambers Edinburgh Journal, June 20, 1846, 389.

${ }^{100}$ Levine, The Spirit of 1848, 114.

${ }^{101}$ Ibid, 113.

102 Ibid.

103 Kathleen Neils Conzen, Immigrant Milwaukee, 1836-1860: Accommodation and Community in a Frontier City. (Cambridge: Cambridge University Press, 1976): 111.
} 
vassals of such a word-breaker." 104 German laborers considered their work as worthy of respect from fellow members of the working class, as well as those who occupied the upper tiers of society.

During strikes, local unions at times honored one another's struggle and boycotted work along with them. Unlike in the German Confederation, Levine points out, German labor groups operated within a country in which there was no "significant guild tradition to which immigrants could appeal." 105 To overcome this challenge, unions invented a distinctly American legacy for themselves, idolizing the works of Thomas Paine and expressing their demands "in the form and language of the Declaration of Independence." ${ }^{106}$ Like the patriots had rebelled against the British colonizers, so, too, the German working-class rebelled against their oppressive employers. In 1853, for example, the Amerikanischer Arbeiterbund changed its motto to “Vereinigtstehenwir, Vereinzelt fallen wir," or "United we stand, divided we fall," to further accentuate their roots in notable patriotic causes in American history. ${ }^{107}$ In the early 1850 s, German labor activism in cities like Cincinnati, Dayton, and Milwaukee, proved the source for regional strikes across the midwest as they encouraged workers to join them in protest of dismal wages, unstable hours, and dangerous working conditions. ${ }^{108}$

On occasion, strikes even united German- and English-speaking workers. In 1853, these two groups combined forces in a Chicago tailoring shop, demanding set prices for their labor and a guaranteed minimum wage. Cabinet makers in Cincinnati followed this example the same year,

\footnotetext{
${ }^{104}$ Conzen, Immigrant Milwaukee, 111.

${ }^{105}$ Levine, "The Migration of Ideology," 13.

${ }^{106}$ Ibid, 15.

107 Ibid.

108 Alison Clark Efford, German Immigrants, Race, and Citizenship in the Civil War Era. (Cambridge: Cambridge University Press, 2013): 36.
} 
repeated again in Louisville, Kentucky, at a furniture company. ${ }^{109}$ Such inter-ethnic endeavors, however, were not without complications. Some German workers in these unions reportedly considered their English brethren "narrow-minded and timid in asserting their rights." 110 AngloAmericans, for their part, criticized German laborers for their outspoken activism. Such behavior cast them "as visionary chatterboxes, impractical hotheads, and dangerous infidels," a common view shared among many Anglo workers, employers, and anti-immigrant nativists alike. ${ }^{111}$ Throughout the 1850s, animosity among the working-class increased as forty-eighters encouraged immigrant groups to preserve what they interpreted as an intellectual superiority to typical Anglo-American workers, and nativists in turn encouraged laborers to view immigrants as the real cause for their lack of economic security and improvement.

Unions, however, did more than protest and strike. They also exhibited a more charitable side, providing the means for workers to maintain employment as well as spreading awareness and concern for dismal wages and working conditions. Purchasing one's own tools for their trade deeply affected working-class neighborhoods. Keil explains that migrants knew of this policy before emigrating through guides that listed up to forty types of instruments needed to find work following their arrival. Altogether, these tools could cost up to twenty percent of one man's annual salary. ${ }^{112}$ One pamphlet listed types of tools needed for a carpenter's trade as well as their costs. The introduction to this guide then remarks that "it is not surprising that the furniture workers' union set up a tool insurance fund for its members." ${ }^{113}$ In addition to their combative

\footnotetext{
${ }^{109}$ Levine, The Spirit of $1848,120$.

${ }^{110}$ Ibid, 126.

111 Ibid.

${ }^{112}$ Keil, German Workers' Culture, 70.

${ }^{113}$ Keil and Jentz, comps. "The Contents of a Carpenter's Tool Box," (C.L. Fleischmann, Erwerbszweige, Fabrikwesen und Handel der Vereinigten Staaten von Nordamerika, mit besonderer Rücksicht auf deutsche Auswanderer[Stuttgart, 1850], 64).
} 
struggle against unfair treatment by their employers, unions sought to alleviate this burden by raising funds to pay for these necessities.

German workers expected the state to play a positive role in protecting laborers from exploitation. German workers envisioned the government as a mediator between employer and employee. These German unions “made demands...that infringed on employers' presumed right unilaterally to govern their enterprises" unchecked and unregulated. ${ }^{114}$ By voicing demands that the government support an environment in which workers could sustain themselves--either through mandating rent costs, illegalizing child labor, setting maximum hours and minimum wages, or abolishing slavery--these immigrant organizations revealed the most pivotal concerns within their communities. Federal intervention would ensure this fair treatment. During economic downturns in the 1850 s, workers called for government aid, speaking on "the right to live not as a mere charity, but as a right." 115 Such demands by workers of German labor unions, Willi Paul Adams recognizes, only grew louder by those who "took the lead" in their communities; namely, the forty-eighters, who possessed the time and popularity with which to garner further support for a range of causes. ${ }^{116}$ Forty-eighter leaders sought to uphold the language and customs of their ethnic group and defend their communities against criticism for their activism.

The most radical of German organizations adopted platforms that considered political reform associated with, though not solely concentrated on, labor concerns. These associations, many of which were short-lived, possessed outlandish goals that did not fail to garner negative attention from anxious nativists. In 1852, a group of Germans in Wheeling, Virginia, held a

\footnotetext{
${ }^{114}$ Levine, "The Migration of Ideology," 13.

115 Ibid.

${ }^{116}$ Willi Paul Adams, "Ethnic Leadership and the German-Americans," in America and the Germans, Volume I: An Assessment of a Three-Hundred Year History. Frank Trommler and Joseph McVeigh, eds. (Philadelphia: University of Pennsylvania Press, 1985): 156.
} 
“Congress of German Revolutionists," in reverence of Louis Kossuth, a Hungarian revolutionary who accumulated his largest support in the United States' German-immigrant neighborhoods. ${ }^{117}$ In 1853, a letter written by St. Louis resident Carl Berthold described Kossuth from the German working-class perspective: "Kossuth is a man of freedom...he made a vow here in America to do everything in his power, to sacrifice life and property for Germany's freedom" from monarchical rule in the Revolutions of $1848 .{ }^{118}$ Not only do Berthold's words speak to the degree of popularity of radical revolutionaries of the era, but he also references lingering German hopes for political participation and representation in their homeland.

Often begun or at least co-opted by forty-eighters, numerous Freimännervereine and Freie Gemeinde developed across the country. These were the political groups most dominantly supported by union craft workers and unskilled laborers. ${ }^{119}$ Like the unions, these groups remained actively involved in community outreach. The socialist supporters within the Cincinnati Arbeiterbund, for example, provided a "cooperative grocery" for poorer residents of the neighborhood. ${ }^{120}$ Also in Cincinnati, forty-eighter Friedrich Hecker founded the first Turnverein in 1849, an organization composed of German men from all economic backgrounds. Other Turnverein were subsequently established in nearby cities like Louisville and St. Louis. The work of August Willich in Cincinnati, however, best serves as an example of the groups with which Karl Heinzen involved himself during his stay in Louisville.

\footnotetext{
${ }^{117}$ Ken Fones-Wolf, "Caught Between Revolutions: Wheeling Germans in the Civil War Era," in Transnational West Virginia: Ethnic Communities and Economic Change, 1840-1940. Ken Fones-Wolf, e and Ronald L. Lewis, eds. (Morgantown: West Virginia University Press, 2011): 25.

118 "Carl Berthold, 'St. Louis, February 2, 1853,"” in News from the Land of Freedom: German Immigrants Write Home. Walter D. Kamphoefner, Wolfgang Helbich, and Ulrike Sommer, eds. (Ithaca: Cornell University Press, 1988): 326.

${ }^{119}$ Wittke, Refugees of Revolution: The German Forty-Eighters in America. (Philadelphia: University of Pennsylvania Press, 1952):166.

120 Ibid.
} 
Mischa Honeck provides an informative chapter on Willich's outreach to the German community in Cincinnati that "actively supported the laborers in their fight for higher wages and better working conditions." ${ }^{121}$ Referred to as the "Reddest of the Red," Willich took over the Cincinnati Republikaner as editor and became leader of the German American Social Workingmen's Club. Like other German organizations, Willich's group offered more than just political meetings and lectures. They also hosted theatre and singing troupes and partnered with the local Turnverein for various recreational activities. Willich was a visible figure in community parades and picnics, speaking to his German audience and supporting a "festive culture" that to reference and celebrate his and other revolutionaries' former actions in 1848 and 1849 and, by doing so, "[kept] alive the memory" of the spirit of $1848 .{ }^{122}$

In addition, famous forty-eighter and communist Wilhelm Weitling's Arbeiterbund contained five thousand members at the height of its success by the early 1850s. It espoused more pragmatic initiatives like insurance programs and pensions, but also idealistically desired to lead a "social revolution and shake off the prevailing system of wage slavery which was depressing workingmen into a hopeless proletariat." ${ }^{123}$ In addition to these goals, offshoots of this national organization--some of which were located in New York City, Milwaukee, Detroit, and even Louisville--hosted theatre productions and singing societies and mostly congregated in beer halls. Weitling's Arbeiterbund is a fitting example for the number of activities undertaken by these grassroots German associations, one of which included the progressive "National Central Union of Free Germans," headquartered in Louisville. ${ }^{124}$

\footnotetext{
${ }^{121}$ MischaHoneck, We are the Revolutionists: German-Speaking Immigrants and American Abolitionists after 1848. (Athens: University of Georgia Press, 2011): 84.

${ }^{122}$ Honeck, We are the Revolutionists, 85.

${ }^{123}$ Wittke, Refugees of Revolution, 173.

${ }^{124}$ Charles Deusner, "The Know-Nothing Riots in Louisville," The Register of the Kentucky Historical Society 61, no. 2 (1963): 125.
} 
Unquestionably, the German-language press proved the largest political weapon for these groups, whether they mainly concerned themselves with spreading awareness to working conditions or political causes as anti-slavery sentiments. From the early 1850 s and into the twentieth century, newspapers served as physical symbols of a flourishing German culture in North America. These sources were also priceless mouthpieces for working-class movements who conveyed their messages in the native tongue of many workers. ${ }^{125}$ For most, forty-eighters resided over them as chief editors, “[voicing] their concerns about American society's obvious shortcomings." 126 Their vast knowledge of current events, communicated to Germans across the country with equally versatile prose, earned them much deserved attention, positive and negative. Also protecting and preserving the German language, these newspapers united all German-American organizations from singing clubs to workers' unions.

The German-language press fought what was considered the inevitable process of their assimilation to Anglo-American lifestyles and values. Steven Rowan writes that these newspapers did not consider themselves "alien or transitional." 127 Rather, as a collective, they served as "the permanent representative of a lasting American minority," a more culturally enlightened group that had much to teach the Anglo population. ${ }^{128}$ For instance, Karl Heinzen theorized that through "the treasures of German science and learning," his fellow community could dissuade Americans out of their Puritanical preoccupations. ${ }^{129}$ The retention of their language remained one of their most important concerns, thus numerous forty-eighter

\footnotetext{
${ }^{125}$ Elliott Shore, Ken Fones-Wolf, and James Philip Danky. The German American Radical Press: The Shaping of a Left Political Culture, 1850-1940 (Urbana: University of Illinois Press, 1992): 5.

${ }^{126}$ Hartmut Keil, "Continuity and Change in the Transfer of Ideologies." Occasional Papers of the German Historical Institute, no. 7 (1992): 22.

${ }^{127}$ Steven Rowan, "The German Press in St. Louis and Missouri in the Nineteenth Century: The Establishment of a Tradition," The Papers of the Bibliographical Society of America 99, no. 3 (2005): 466.

${ }^{128}$ Rowan, "The German Press in St. Louis and Missouri in the Nineteenth Century," 466.

${ }^{129}$ Wittke, Against the Current, 299.
} 
newspapers advocated for German-language instruction in schools. For decades and until the First World War, many areas complied with this demand. ${ }^{130}$ Beginning in the 1840 s, Cincinnati's public schools provided classes in both English and German languages. ${ }^{131}$ The fight to preserve language and community customs combined with the struggle for reforms in the workplace and politics resulted in galvanized German neighborhoods across the country.

According to Levine, "economic hardship" experienced by many of these immigrants upon arrival to the United States was softened due to such strong cohesiveness of community "across bounds of social class" and political ideologies. ${ }^{132}$ The German-American press and groups like the Arbeiterverein and Turnvereine united Germans simply as members of one neighborhood. ${ }^{133}$ As Keil explains, labor and social organizations frequently developed in order to combat "an unfamiliar and often hostile society" by preserving a sense of normalcy in their neighborhoods. ${ }^{134}$ German immigrants simultaneously confronted many societal challengesespecially when they partnered with former revolutionaries - through the press, labor unions, aid programs, as well as in beer halls, Sunday picnics, singing societies. In addressing difficulties as a common struggle, as well as celebrating shared culture and practices, German communities often fostered pride and activism that gave rise to negative attention on the part of nativists.

In Louisville, German workers and their forty-eighter community leaders directly confronted the realities of their struggles as minorities within the working class. They subsequently created and expanded outreach programs in a region dominated by nativist politicians and their rising rhetoric against workers' collectivization and the preservation of

\footnotetext{
130 Paul Fessler, "The Political and Pedagogical in Bilingual Education: Yesterday and Today," in GermanAmerican Immigration and Ethnicity in Comparative Perspective. (Madison: Max Kade Institute for GermanAmerican Studies, 1997): 273.

${ }^{131}$ Fessler, "The Political and Pedagogical in Bilingual Education," 273.

${ }^{132}$ Levine, The Spirit of 1848, 83.

${ }^{133} \mathrm{Ibid}, 93$.

${ }^{134}$ Keil, German Workers' Culture, xvii.
} 
German language and culture--undeniably a source of strength for the immigrant laborers. Through Heinzen and other forty-eighters' contributions to the community's activist spirit, awareness and frustration on the part of the German community toward their economic and social struggles increased and led to numerous organizations designed to combat these problems that plagued their neighborhoods.

\section{Relocation to Louisville's Germantown}

Upon Heinzen's return to the United States in October of 1850, his notability as a participant in the Revolutions of 1848 had waned considerably. New York City Germans' hopes in democratic causes abroad had by then deflated as they accepted the return to monarchical rule in their homeland and carried on with their lives. For a short period, Heinzen took up a job as a painter for three dollars a week. ${ }^{135}$ By winter of 1851 , however, Heinzen had retained his former editorial position at the Schnellpost. Tensions soon surfaced when his coworkers suggested that the Schnellpost tie itself to the Democratic party to ensure its survival through political ads and donations. Heinzen adamantly rejected this proposal, as "he would force people to listen to the truth as he saw it...[steering] clear of all party ties and commitments and remain absolutely independent. ${ }^{" 136} \mathrm{He}$ ultimately rejected the existing parties of the United States and transformed his rhetoric into a philosophy of total democracy. Evidently weary of forming alliances, the middle-aged radical turned his political views into his own platform. At one point, however, he had put forward the idea of Germans establishing their own political party to combat the growing anti-immigrant rhetoric among both parties at the time. ${ }^{137}$

\footnotetext{
${ }^{135}$ Wittke, Against the Current, 82.

${ }^{136} \mathrm{Ibid}, 84$.

${ }^{137}$ Ibid, 289.
} 
Yet Heinzen's uncompromising attitude lost him more friends and readership than it gained. The extreme language that he used in reference to organized religion and authority simply repelled subscribers. He managed, however, to maintain an audience who resided across the country and throughout the world. The Schnellpost went through various instances of rebranding, its ferocious spirit kept alive in other works that Heinzen attempted to establish. By 1852, Heinzen announced the closing of his editorial office in New York City. Not long afterward, he promptly proclaimed the publication of Janus, and to raise money for its success, conducted an unsuccessful lecture tour across the east and midwest. Hardly anyone attended his speech in Philadelphia, though the local singing society held a concert in his honor. Throughout Ohio, he faced the fury of German Democrats whom he accused of being sympathizers to the Southern institution of slavery. ${ }^{138}$

At this point, Heinzen had lost much of his patience with his fellow German-Americans. He felt that their religious piety prevented them from embracing his radical republican ideals. $\mathrm{He}$ and his family, in dire financial straits, constantly moved around New York City from boarding house to boarding house, selling belongings to manage their debts. Fortunately, as total economic ruin loomed, Heinzen received an invitation to edit the Herold des Westens in Louisville, Kentucky. ${ }^{139} \mathrm{He}$ did not accept this invitation immediately as he admitted in Erlebtes years later that the idea of living within a slave state had greatly disturbed him. ${ }^{140}$ Eventually, the dire state of his family's finances forced Heinzen to change his mind on the prospect. Remarkably, however, it was in this slave state that he would experience some of the most successful and controversial enterprises of his long career in the United States, as by this time, the city possessed a thriving politically-active German community. Interestingly, it was also in Louisville

\footnotetext{
${ }^{138}$ Ibid, 89.

${ }^{139}$ Ibid, 91.

${ }^{140}$ Heinzen, Erlebtes, 500.
} 
that Heinzen's priorities shifted from idealistic revitalization of revolution abroad to addressing general struggles that afflicted many immigrant neighborhoods in the mid-nineteenth century United States.

This politicized community could not have existed without the strong support of local, working-class Germans who had lived there prior to Heinzen's arrival in 1853. By 1850, Louisville was the fourteenth-largest city in the country due to its lucrative trading and shipping location along the Ohio River. ${ }^{141}$ A map of the city, created by J.H. Colton in 1855 , is shown in Figure 2 at the end of the chapter. Almost eight thousand of the city's residents were German, out of a total population of a little over forty-three thousand. ${ }^{142}$ Half of Louisville's Germans were Catholic, a larger proportion than most cities in the United States at the time. Their first church, St. Boniface's, was established in 1837. Already by 1841, a second parish, St. Mary's, was needed to meet rising demand in different neighborhoods. ${ }^{143}$ The most well-known St. Martin of Tours, depicted in Figure 3, was built in 1853. At this point, the tall structure rose above all other churches as a symbol of pride for German Catholic immigrants. No more than two years later, a fourth parish, St. Peter's Church, was founded. ${ }^{144}$

Protestant congregations also increased. St. Paul Evangelical Church, established in 1836, was the first German-speaking parish in the area. The First German Methodist Church followed suit in 1841. Other Evangelical and Methodist German Protestant churches quickly arose throughout the 1840s and 1850s. ${ }^{145}$ According to Avraham Barkai, about one-fifth of all

\footnotetext{
141 Sister Martha Jacob, OSU, "Ursaline Sisters and Catholic Schools," in Germans in Louisville: A History (Heritage Press, 2015): 48.

142 John E. Kleber, "Immigration, Xenophobia, and Bloody Monday," in Germans in Louisville: A History (Heritage Press, 2015): 29.

143 Jacob, "Ursaline Sisters," 49.

144 Kleber, "Immigration," 38.

145 Reverend Gordon A. Seiffertt, "Protestant Churches," in Germans in Louisville: A History (Heritage Press, 2015): 55-56.
} 
Germans who settled in the Ohio and Mississippi Valleys in the early- to mid-nineteenth century adhered to the Jewish faith. Specifically, Louisville "had an early reputation as one of the first Jewish settlements" of the region, with a Jewish cemetery already erected by $1830 .{ }^{146}$ By 1849 , German Jews in Louisville constructed the city's largest synagogue, Adas Israel, in the Reformed faith.

The Germans who filled these congregations brought a variety of necessary skills with them to the River City after 1848, one of which was in butchering. Germans dominated Louisville's meat industry to such an extent that one of their neighborhoods was soon called "Butchertown" by locals. ${ }^{147}$ Craftworkers occupied many other trades, as well. Bavarian immigrant Gustav Schimpff opened one of the city's first candy stores in the 1850s. ${ }^{148}$ In 1852 , John Henry Wrampelmeier of Prussia opened his own furniture store and a couple of years later, Gustave Bittner of Silesia opened his own woodworking business that also contributed to steamboat construction. ${ }^{149}$ In 1854 , immigrant Carl Berthold spoke to the prosperity that he had experienced upon moving to Louisville, writing to his family in Hesse that "I haven't found any city any better and healthier than Louisville. [It] is quite nicely built up, has good drinking water... A tenth of Louisville is now made up of Waldeckers (Hessians)" like himself. ${ }^{150}$ Germans soon dominated breweries in the area. Conrad Selle and Peter Guetig point out that by 1848 , "three of the five breweries in Louisville had Swiss or German proprietors." 151 The William Tell Brewery, Jacob Fischer's Brewery, and Adolph Peter's Brewery were three of the

\footnotetext{
${ }^{146}$ Avraham Barkai, Branching Out: German-Jewish Immigration to the United States, 1820-1914. (New York City: Holmes and Meier, 1994): 72.

${ }^{147}$ Edna Kubala-Mott, "Butchertown," in Germans in Louisville: A History (Heritage Press, 2015): 111.

148 Gary Falk, "Manufacturing," in Germans in Louisville: A History (Heritage Press, 2015): 129.

149 Falk, "Manufacturing," 132-133.

150 "Carl Berthold, 'Louisville, June 3, 1854," in News from the Land of Freedom: German Immigrants Write Home. Walter D. Kamphoefner, Wolfgang Helbich, and Ulrike Sommer, eds. (Ithaca: Cornell University Press, 1988): 329.

151 Conrad D. Selle and Peter R. Guetig, "Breweries," in Germans in Louisville: A History (Heritage Press, 2015): 88.
} 
first breweries opened in the city. Others subsequently followed in the next couple of decades. Most of these breweries also managed saloons or Lokals to sell their products. Jacob Matheus' “deutsches Wein und Bierhaus," Schrodt and Laval's Tavern, the Wenzel Street Tavern, Walnut Street Tavern, Jackson Street Tavern, Anton Bader's Portland Exchange, Georg Besser's Kentucky Hall, Michael Dies’ Kentucky Tavern, and Henry Fischer's “deutsches Bierhaus” are just a handful of examples that depict the prevalence of Lokals within Louisville's German neighborhoods. In addition, a considerable number of these Lokals managed beer gardens (one of which is shown in Figure 4). Incredibly, by the end of the nineteenth century, Germans and their descendents operated ninety percent of the taverns in Louisville. ${ }^{152}$

One of the first advertisements in the Louisville Anzeiger, a popular liberal Germanlanguage newspaper and depicted in Figure 5, promoted these German breweries and Lokals. ${ }^{153}$ Of the fourteen local German publications at the time, five were considered politically radical in content. ${ }^{154}$ Other social outlets were the Liederkranz, Louisville's most prominent singing society and whose building is shown in Figure 6, and the city's Turner branch, founded in 1850, whose original local headquarters is depicted in Figure 7. Some members of these groups had ties and memberships to labor organizations and political groups with which Heinzen would interact upon his arrival in $1853 .{ }^{155}$ These groups apparently teamed together during strikes at certain times, as was announced in a column of the Louisville Journal in September of 1853. The notice read that "a number of Finishers and Turners are wanted at the American Foundry, some

\footnotetext{
152 Conrad D. Selle and Peter R. Guetig, "Saloons and Beer Gardens," in Germans in Louisville: A History (Heritage Press, 2015): 96-97.

${ }^{153}$ Selle and Guetig, "Saloons and Beer Gardens," 96.

${ }^{154}$ Kevin Collins and Kathleen Pellegrino, "Newspapers," in Germans in Louisville: A History (Heritage Press, 2015): 82.

155 Gary Falk, “The Turners," in Germans in Louisville: A History (Heritage Press, 2015): 109-110.
} 
of the old hands having quit work" because they had yet to be paid their wages. ${ }^{156}$ Based on these actions, it is clear that the ideas espoused by the leaders of these German organizations inspired immigrant workers to unabashedly challenge injustices.

In addition to these active and growing societies, Louisville's Germans had also created Freier Gesellschaftsbund, freethinkers' clubs, who welcomed "the great Karl" into their ranks. ${ }^{157}$ Heinzen was not even the first controversial figure to visit the River City. In 1852 alone, August Willich and Wilhelm Weitling established temporary residences. ${ }^{158}$ That same year, Louis Kossuth had made a stop there on his nation-wide tour. He spoke in front of the luxurious Galt House, with almost thirty thousand people in attendance. ${ }^{159}$

Once Heinzen had taken over the Herold des Westens and unleashed his fiery rhetoric upon the city's German community, conflict immediately arose between the religious and radical population. The consequences of Heinzen's incendiary remarks against Catholicism and monarchism were never so pronounced than when unnamed arsonists burned the editing office of the Herold to the ground on December 5, 1853. ${ }^{160}$ Heinzen, however, was by now accustomed to negative reception. Not even three months following this incident, he established the paper for which he served as the editor for the rest of his life, Der Pionier. In Teutscher Radikalismus in Amerika, Heinzen explains that he founded this paper to try and convince his fellow Germans in Louisville that they did not have to fear and bow "to every narrow-minded and close-minded little master," presumably one of native-born citizenship. ${ }^{161}$

\footnotetext{
${ }^{156}$ Louisville Journal, Thursday, September 15, 1853, 2.

${ }^{157}$ Wittke, Against the Current, 91.

158 Sister Agnes G. McGann, Nativism in Kentucky to 1860. (Washington, D.C.: Catholic University Press, 1944): 50.

${ }^{159}$ McGann, Nativism in Kentucky, 60.

${ }^{160}$ Wittke, Against the Current, 92.

${ }^{161}$ Karl Heinzen, Teutscher Radikalismus in Amerika: Ausgewählte Abhandlungen, Kritiken und Aphorismenaus Den Jahren 1854-1879. (Milwaukee: Freidenker Pub. Co., 1890): 22.
} 
Soon, Der Pionier had built up a readership that stretched across the country and the world. ${ }^{162}$ From the paper's conception, reprints of his articles could be found in European newspapers. The many issues that he published throughout his life explored Heinzen's most controversial positions, such as the end of currency and support for the free love movement. ${ }^{163}$ Contemporary radical Jacob Mueller praised Heinzen's newspaper because it "sets the tone for the German press of the country." ${ }^{64}$ The "thundering Jupiter," as Mueller referred to his fellow forty-eighter, Heinzen "threw his lightning bolts at everyone...who sinned against radicalism." 165 Furthermore, Mueller likened Heinzen's effect on the American masses to "a bomb thrown into a harmless crowd which explodes, blinding and terrifying," certainly a reference to Heinzen's later influence over early European anarchist and nihilist movements. ${ }^{166}$

On the local level, his actions were slightly more subdued. In Louisville, Heinzen joined and apparently at one point headed the National Central Union of Free Germans. This local organization strongly supported reforms of the time that working-class communities supported, such as abolitionism, expansion of women's rights, anti-temperance legislation, and free soil. ${ }^{167}$ Through Der Pionier, he advertised and popularized local social groups like the Turnverein, the Bund Freier Männer and other workers' unions, political clubs, as well as the Bund Freier Frauen, aiding in the increase of their membership numbers and outreach. ${ }^{168}$

Heinzen was never so bold during his stay in Louisville than in February of 1854, when he and a group of radicals composed the Louisville Platform. This document and its

\footnotetext{
${ }^{162}$ Wittke, Against the Current, 93.

${ }^{163}$ Henry Boernstein. Memories of a Nobody: The Missouri Years of an Austrian Radical, 1849-1866. Steven Roward, trans. and ed. (St Louis: Missouri Historical Society, 1997): 176.

164 Jacob Mueller, Memories of a Forty-Eighter: Sketches from the German-American Period of Storm and Stress in the 1850s. 1st English ed. (Cleveland, OH: Western Reserve Historical Society): 166.

${ }^{165}$ Mueller, Memories of a Forty-Eighter, 166.

${ }^{166} \mathrm{Ibid}, 222$.

${ }^{167}$ Deusner, "The Know Nothing Riots in Louisville," 125.

${ }^{168}$ Carl Wittke, The German Language Press in America. (Lexington: University of Kentucky Press, 1957): 86.
} 
proclamations will be explored in the next chapter, though it is important to emphasize that the declaration made Louisville, of all towns in the United States, "the seat...[of]...a new political party." 169 This German-based party would have as its "cardinal principles" the "abolition of slavery" as well as what contemporaries referred to as "puritanismus." 170 Those who opposed these two facets of American society displayed hostility to nativist, Southern apologists, as well as advocates for temperance. In other words, nearly all elements of the Know-Nothing movement had been attacked in Heinzen's seven-page proclamation. In the next chapter, the reaction on the part of Know-Nothing supporters and party members will therefore follow an intensive analysis of the Platform's core beliefs and their origins in Heinzen's philosophy.

${ }^{169}$ Baker, Young Germany in America, 79.

${ }^{170}$ Ibid, 78-79. 


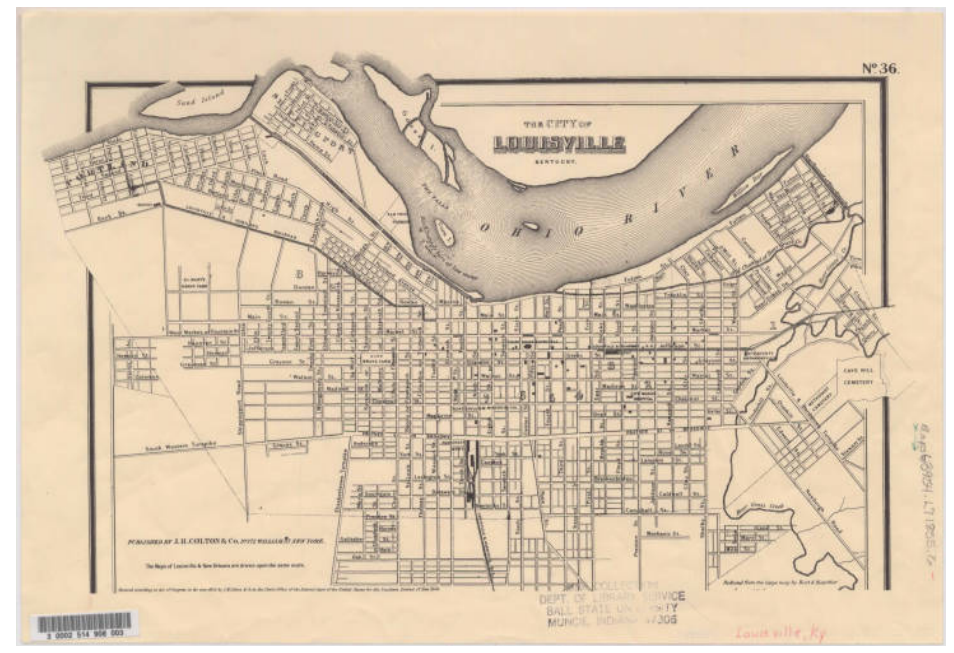

Figure 2: Map of Louisville, 1855. Courtesy Ball State University Digital Media Repository.

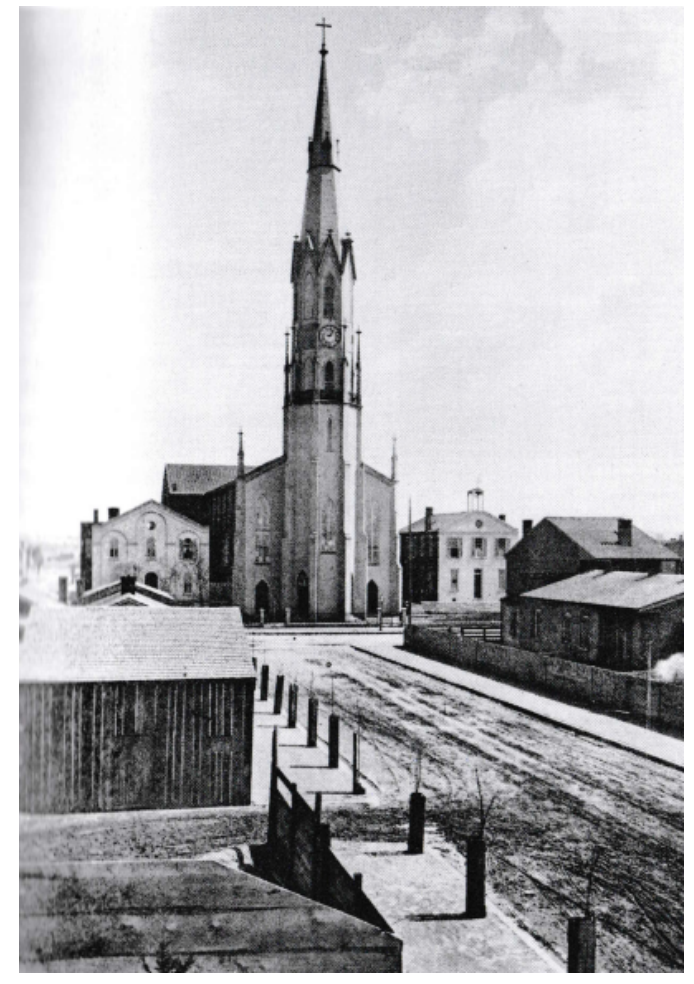

Figure 3: St. Martin of Tours Cathedral, 1870. Courtesy University of Louisville Photographic Archives. 


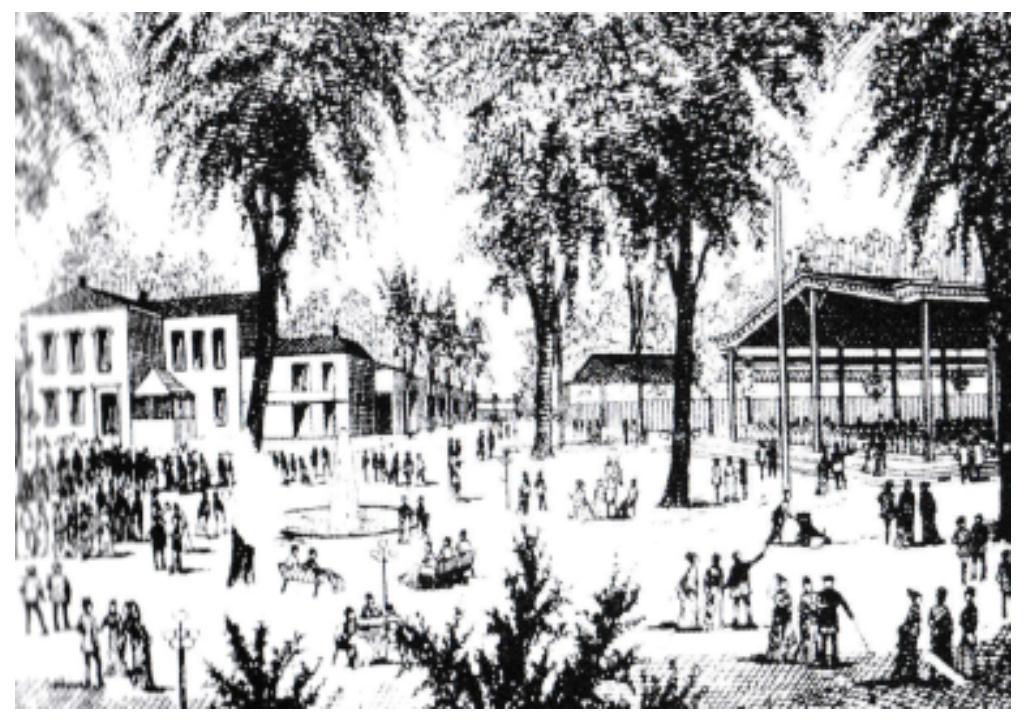

Figure 4: Woodland Garden, a popular beer garden in Louisville. New York Daily Graphic, April 29, 1875.

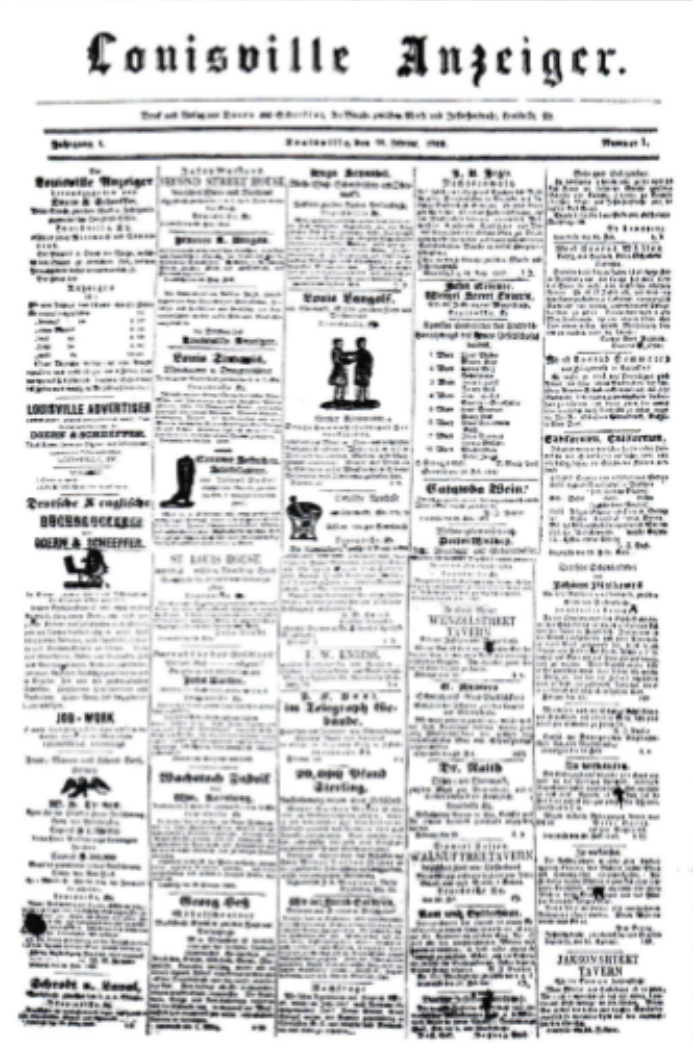

Figure 5: Issue of the Louisville Anzeiger, February 28, 1849. Courtesy Filson Club Historical Society. 


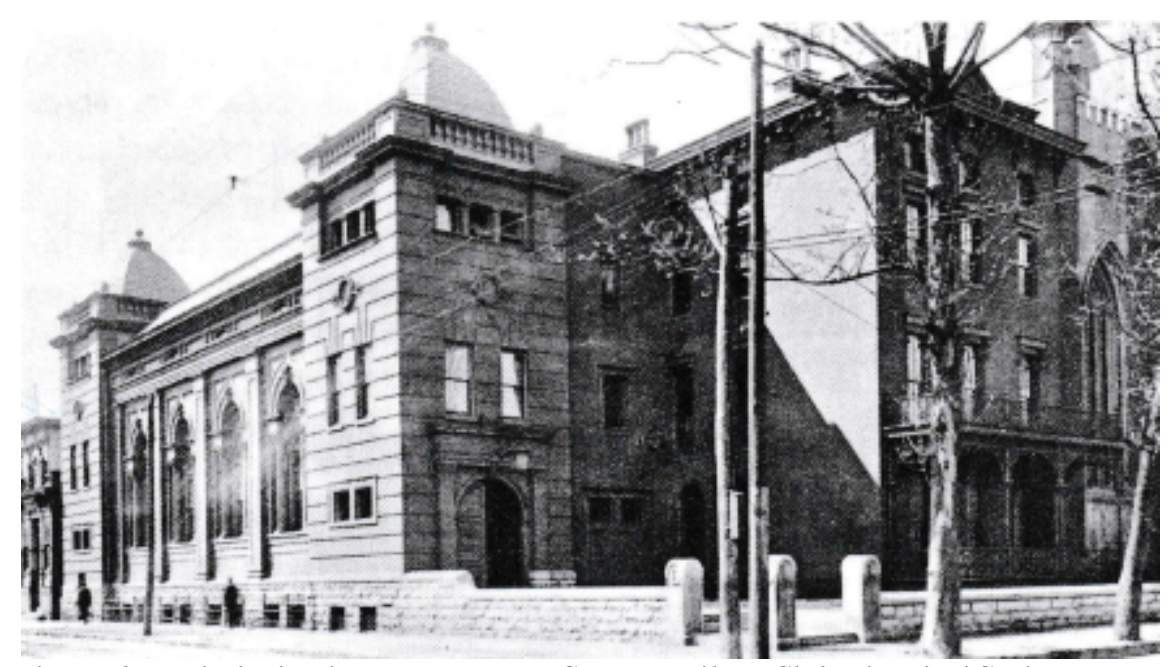

Figure 6: Louisville's Liederkranz Hall. Courtesy Filson Club Historical Society.

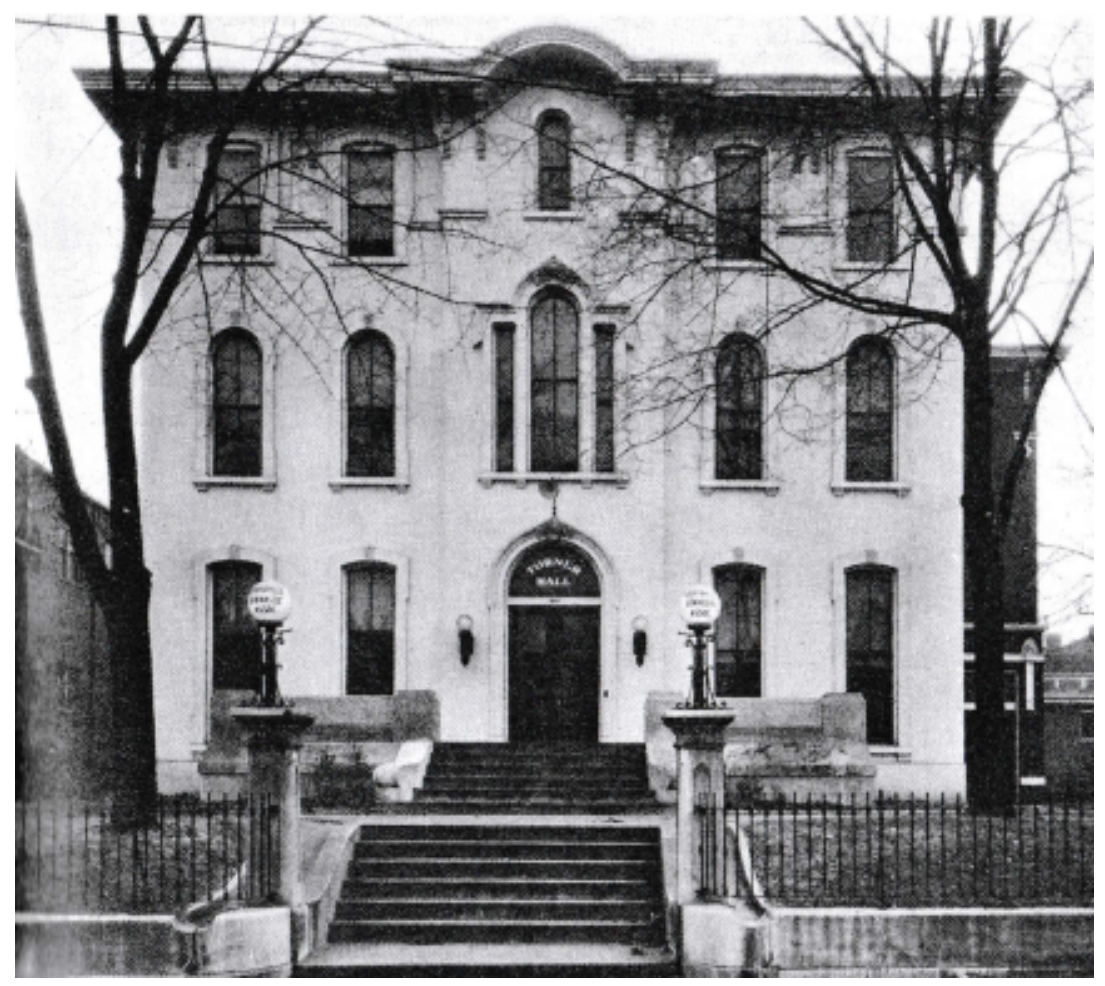

Figure 7: Louisville's Turnverein building, or “Turner Hall.” Courtesy Filson Club Historical Society. 


\section{Chapter II: The Louisville Platform as a Roadmap for Republicanism}

On February 19, 1854, following a week's long assembly in the city’s Apollo Hall, Heinzen and fellow radical forty-eighters and their allies of the Bund Freier Männer published the "Union of the Germans," along with the first issue of Der Pionier. Directed "To All True Republicans in the Union," the proclamation called for "Liberty, Prosperity, and Education for All," slogans similar to those used in Heinzen's publications from 1848to rally support the German Confederation and Baden. ${ }^{1}$ The language and political world view expressed in the Platform is important to contextualize. When he addressed his fellow "Republicans," Heinzen and his co-signers did not call to action an emerging political party, but rather drew on a political philosophy associated with their fight for democratic reform in 1848 . The legacy of the Revolutions of 1848 resonated that day in the meeting hall as they issued the proclamation.

Seven or eight pages in length, the Louisville Platform was designed to serve as a constitution for "a coalition" of liberal and "free" Germans and to form an alliance with "ALL TRUE AMERICANS, IE. ALL TRUE REPUBLICANS.”"2 The Platform raised important distinctions between corrupt Anglo-Americans and American Republicans and between "those grand principles of the Declaration of Independence and of the Constitution," and the corruption and lack of fulfillment of those principles. Indeed the Platform claimed that that the key principles of the Founders have been, "renounced and corrupted in all important and final questions by a policy inimical to the true interest of the people." ${ }^{3}$ Heinzen and his co-authors sought to remind Americans of their inherent rights based on republican values. ${ }^{4}$ The Platform

\footnotetext{
${ }^{1}$ Carl Wittke, Against the Current: The Life of Karl Heinzen (1809-80). (Chicago: University of Chicago Press, 1945): 94.

2“Louisville Platform.” Louisville, Kentucky, March 1854. In The German-American Forty-Eighters, 1848 1998.Don Heinrich Tolzmann, ed. (Indianapolis: Max Kade German-American Center, 1998): 98.

3 "Louisville Platform," The German-American Forty Eighters, 99.

4 Ibid.
} 
listed and elaborated on many of the core values of their interpretations of republicanism as a whole, as well as its potential for reforming the United States. The German-led coalition which they hoped would originate from the Platform was meant to resolve American shortcomings with their own visions, brought about and delivered by exiles and immigrants who believed in the progressive goals of the Revolutions of 1848 and 1849.

The Platform began with a denunciation of slavery, regarded as a "political and moral cancer" in need of obliteration. ${ }^{5}$ Furthermore, Heinzen expressed his extreme opinion on the plight of African Americans, explaining that "the color of the skin cannot justify a difference of legal rights," and thus that all people—including women, he added — had the right to equal access of all liberties and freedoms granted them under the Constitution. ${ }^{6}$ Indeed, Slavery appeared at the top of their list of abhorrent economic practices in the United States, thus drawing significant attention from nativists who feared it could permanently divide the country. Heinzen's immediate targeting of slavery is not surprising considering his longstanding commitment to human rights dating from his early travels to Batavia. Living in a border state that tolerated slavery fueled his determination to challenge this abomination in a republic. Heinzen recalled his arrival to Louisville in Erlebtes, noting when he saw advertisements posted for slaves "it was like the air had changed" and only grown more oppressive after he had crossed the border into a slave state. ${ }^{7}$

Most forty-eighter exiles in the United States opposed slavery. They adhered to the philosophy of Georg Wilhelm Friedrich Hegel, or Young Hegelianism, that considered a

${ }^{5}$ Ibid, 101.

${ }^{6} \mathrm{Ibid}, 104-105$.

${ }^{7}$ Karl Heinzen, Erlebtes. (Boston: Selbstverlag des verfassers, Volumes 1 and 2, 1864-1874): 503. 
"compromise between freedom and slavery impossible." 8 The United States could either continue with its "imperfect reality" or actualize its "ideal theory," the abolition of slavery. ${ }^{9}$ Though Heinzen's fellow German radicals never missed an opportunity to condemn slavery, Andre Fleche writes that "the institution of slavery seemed to replicate the social structure dominated by large landholders and privileged aristocrats that revolutionaries had sought to supplant in almost every revolution since $1789 .{ }^{\prime \prime 10}$ Certainly, the Revolutions of 1848 - still prominent in the minds of many former radicals — had contained such demands, as well. To push this comparison, a majority of forty-eighters focused on the plight of the rural poor under the thumb of slavery rather than the black enslaved themselves. ${ }^{11}$

Heinzen, however, focused more on the plight of African American slaves. He considered war on slavery as necessary in achieving a "truly republican society," and that opponents would indeed need to perish to reach such an improved state of governance. ${ }^{12}$ Heinzen made his position all the more controversial when he encouraged "black agitators" to "rise up against oppression." ${ }^{13}$ He supported the idea of a "separate African American agency" to abolish slavery, a feature of his ideology not even shared by a majority of white abolitionists. ${ }^{14} \mathrm{He}$ thus realized the potential for black activism in an era when the intellectual and organizational capabilities of black people were hardly acknowledged or supported.

\footnotetext{
${ }^{8}$ Daniel Nagel, "The German Forty-Eighters' Critique of the U.S. South," in The U.S. South and Europe: Transatlantic Relations in the Nineteenth and Twentieth Centuries. Cornelius A. Van Minnen and Manfred Berg, eds. (Lexington: University of Kentucky Press, 2013): 54.

${ }^{9}$ Nagel, "The German Forty-Eighters' Critique of the U.S. South," 54.

${ }^{10}$ Andre M. Fleche, The Revolution of 1861: The American Civil War in the Age of Nationalist Conflict (Chapel Hill: University of North Carolina Press, 2012): 32.

${ }^{11}$ Nagel, "The German Forty-Eighters' Critique of the US South," 56.

${ }^{12}$ Ibid, 54.

${ }^{13}$ Mischa Honeck, We are the Revolutionists: German-Speaking Immigrants \& American Abolitionists after 1848. (Athens, GA: University of Georgia Press, 2011): 149.

${ }^{14}$ Honeck, We are the Revolutionists, 149.
} 
Likewise, a majority of ordinary working-class Germans condemned slavery. Generally, politically-minded laborers wished to contain the institution from spreading west and occupying free land so it would not compete with wage labor. Though there were certainly exceptions to this trend as Germans like others focused on self-interest, German workers did not lash out against African Americans nearly as often as members of the Irish working-class, who competed with the latter demographic on far more numerous occasions than Germans. As Hartmut Keil explains, "lack of labor competition made for friendly mutual perceptions between German immigrants and people of color." 15

Black abolitionists also took notice of German radicals and their voices of support for the eradication of slavery in the United States. In fact, Frederick Douglass had kept a watchful eye on Central European revolutionaries since the beginning of their activism in 1848. Andre Fleche explains that Douglass considered the events of 1848 and 1849 as premonitions for the future of the United States. At the time, Douglass predicted that "the downfall of monarchy in the Old World foretold the downfall of slavery in the New." 16 A few years later, Douglass addressed the position of anti-slavery that German immigrants generally espoused more than any other white ethnic group in the 1850 s, observing that "many noble and high-minded men, most of whom, swept over by the tide of revolution of 1848 , have become our active allies against oppression and prejudice." ${ }^{17}$ Similar to Douglass’ views, forty-eighters considered enslaved African Americans as kindred spirits in their fight against corrupt hierarchies.

\footnotetext{
${ }^{15}$ Hartmut Keil, "Alexander von Humboldt, The German Immigrant Community, and Antebellum Politics." Przeglogon ad polonijny31, no. 4 (2005): 15. See also Kristen Layne Anderson, Abolitionizing Missouri: German Immigrants and Racial Ideology in Nineteenth-Century America, (Baton Rouge: LouisianaStateUniversity Press, 2016)

${ }^{16}$ Fleche, The Revolution of $1861,18$.

${ }^{17}$ Hartmut Keil, "German Immigrants and African-Americans in Mid-Nineteenth Century America," in Enemy Images in American History.Ragnhild Fiebig-von Hase and Ursula Lehmkuhl, eds. (Oxford: Berghahn Books, 1997): 156-157. Originally published under “Adopted Citizens and Slavery," in Douglass's Monthly, August 1859.
} 
The Louisville Platform then addressed the principle of religious freedom, as the composers described the freedom of religion as "untouchable," though they remained "opposed to all compulsion to faith" as it was an "open violation of human rights." 18 Though Heinzen and his co-authors expressed tolerance on the topic of religion, they revealed a bit of hypocrisy reminding their audience that "Catholicism is highly dangerous" for what they viewed as monarchical loyalties to the Pope. ${ }^{19}$ The composers' reference to "compulsion to faith," however, should be interpreted as a direct attack to sabbatarian laws and temperance legislation, which will be addressed below.

Women's rights also appeared in the Platform. Heinzen asserted that women are among those individuals "who are created equal," as is laid out in the Declaration of Independence. ${ }^{20}$ Heinzen's ideas on the equality and liberation of women reveal their relationship to republican ideology and elements of all other positions laid out in this unprecedented proclamation. Heinzen's Rights of Women and the Sexual Relations, published roughly around the same time as the Louisville Platform, elaborated and expanded upon Heinzen's visions for true republicanism and its fulfillment within the United States by way of extension of rights and liberties to all of humanity. He first outlined the general problem that "men have made the rights, men have made the morals, men have made the duties, men have made the laws, and they have taken good care that women should be excluded as much as possible from everything." ${ }^{21}$ It was crucial, therefore, to introduce women into every facet of American society, including politics and economics.

The ultimate position for women was for her to be able to "freely act out her nature by means of every aid" that men received from society, such as an education or career, so she could

\footnotetext{
18 “Louisville Platform," 101.

${ }^{19}$ Ibid.

${ }^{20}$ Ibid, 104-105.

${ }^{21}$ Karl Heinzen, The Rights of Women and the Sexual Relations. (Chicago: Charles H. Kerr \& Company, 1891): 33. Originally published by Heinzen in 1852.
} 
also realize her full potential in life. ${ }^{22}$ Heinzen identified that marriage should only be "made dependent on nothing save the conditions for its existence," or for as long as the two parties loved one another. ${ }^{23}$ In other words, religious definitions by way of the priest, laws determining the legalities of marriage, as well as familial preferences through the parents' approval or disapproval should have nothing to do with whether a marriage took place or not. Should that marriage end in failure, both parties were to be allowed to part ways without further attachments or conflict.

Heinzen used his ideal definition of marriage as an example of his goal for the independence of all humanity. Women in particular were central to Heinzen's plans for a future American Republic because they, too, were part of humanity. He implored that "women must enter the ranks of the revolution for the object is the revolution of humanity" as a whole..$^{24}$ Furthermore, "as a human being and as a member of the body social, she has the same right to...an [independent existence]...as the man." ${ }^{25}$ The United States, within its legislative treatises, contained the tools needed to establish and acknowledge such a status for women, only it had not extended those rights to everyone. Thus, Heinzen believed that those liberties and assertions of equality should be applied to all regardless of sex. ${ }^{26} \mathrm{He}$ emphasized this point in Teutscher Radikalismus in Amerika, explaining that "I want to bring awareness to the radical ideal and recognition that all must unite, whether they wear a smock or a fur, whether they work with a pen or a hammer, whether they are a man or a woman., ${ }^{27}$

\footnotetext{
${ }^{22}$ Heinzen, The Rights of Women, 38.

${ }^{23} \mathrm{Ibid}, 98$.

${ }^{24}$ Ibid, 166 .

${ }^{25} \mathrm{Ibid}, 152$.

${ }^{26} \mathrm{Ibid}, 157$.

${ }^{27}$ Karl Heinzen, Teutscher Radikalismus in Amerika: Ausgewählte Abhandlungen, Kritiken und Aphorismenaus Den Jahren 1854-1879. (Milwaukee: Freidenker Pub. Co., 1890): 23-24.
} 
Heinzen would repeat such sentiments throughout his life, especially during his stay at the home of women's rights activist and physician, Dr. Marie Elizabeth Zakrzewska, who greatly respected the radical's views on the matter. ${ }^{28}$ Yet these visions extended beyond increased freedom and equality for women. Indeed, Heinzen ended his book on the matter by returning to the legacies of the Revolutions of 1848 , foretelling that the ideas from such a time "will also have an immense influence upon North America." ${ }^{29}$ After all, "if the air has been cleared by a thunder-shower over there, many a cloud will likewise disappear in the West from the heaven of humanity." 30 In addition, he proclaimed that the "European revolution is the most powerful ally of the women of America" for what he believed was its certain impact on the progression of republicanism within the United States. ${ }^{31}$

Much of the Louisville Platform called for reforms that focused on "The Welfare of the People." One of the opening statements of the proclamation invited people to respond with their opinions about its content, encouraging and welcoming healthy debate and freedom of expression. The Platform also stated that "the welfare of the nation should be permanently secured by releasing the laboring classes from the oppression of the capitalist." Heinzen and his co-authors envisioned an active state protecting workers rights. Should negotiations fail between employer and employee, for example, "the State, as the arbitrator of all interests, has to interfere." 32 Intervention on the part of the federal government involved increased regulations,

\footnotetext{
${ }^{28}$ Marie Elizabeth Zakrzewska, Marie Elizabeth Zakrzewska: A Memoir. (Boston: New England Hospital for Women and Children, 1903): 16.

${ }^{29}$ Heinzen, The Rights of Women, 158.

${ }^{30}$ Ibid, 158-159.

${ }^{31}$ Ibid, 161.

32 “Louisville Platform," 103.
} 
such as standardizing minimum wages and restricting the regular work schedule to no more than ten hours per day. ${ }^{33}$

Furthermore, the Platform defended the rights of the foreign-born population and called for an Office of "colonization and emigration" that would aid and protect poor emigrants from exploitation, since "emigration is the mother of this republic." ${ }^{34}$ In addition, Heinzen argued that "admission to citizenship must be rendered as easy as possible to emigrants escaping monarchism and despotism." 35 These groups, like the rest of the population, should also have equal and free access to education, and their native language spoken along with English in all public schools with a sizable German minority. ${ }^{36}$

In an open address to the temperance movement, Heinzen denounced their advancements to limit the consumption of alcohol as "tyrannical encroachments upon individual liberty and narrow-minded manifestations of an entire misconception of the legislative duties." ${ }^{37}$ His fellow immigrant population deeply resented such measures as they sought to suppress immigrant culture and leisure. Because Heinzen considered the voice of the foreign-born just as important as that of the native citizenry, he declared that every law must "originate with the people," and therefore "all laws must be created by them." 38 The Platform also condemned efforts by nativist governments to undermine and diminish working-class immigrants' rights to representation and collectivization. Finally, the Platform advanced the power of the vote to inspire its reader to participate in civic life and help "decide the victory in favor of a party of true reformers." 39

\footnotetext{
${ }^{33}$ Ibid.

${ }^{34}$ Ibid.

${ }^{35}$ Ibid.

${ }^{36}$ Ibid.

${ }^{37}$ Ibid, 105.

${ }^{38}$ Ibid, 100 .

${ }^{39} \mathrm{Ibid}, 98$.
} 
The Louisville Platform stated in blunt words "what was wrong with the United States and suggested reforms in an alliance between liberal Germans and progressive Americans." ${ }^{40}$ Positions such as the abolition of slavery, equality among the sexes, and worker's rights and reforms, argues John Kleber, paralleled numerous components of the goals of the Frankfurt Parliament that radical German democrats like Heinzen had fought an ultimately hopeless battle to protect and defend in 1848 and $1849 .{ }^{41}$ The overview of Heinzen's publications during his formative years in the German Confederation and in exile and his publications from 1848 that featured the struggle in Baden, all contain early expressions of the key principles that emerged in the Louisville Platform. Furthermore, his experiences in the United States directed him to new objectives that include opposition to slavery as he supported human rights, the protection and empowerment of immigrants, and the importance of using the vote to affect change. The Platform was a call to action for the organization of new movements. It sought to mobilize free Germans and their allies to assert and exhibit their republican beliefs and rights, one of the most important of which was the right to participate in elections at every level. This would spell major consequences for the Germans of Louisville in just a short period, but the immediate effect of the Louisville Platform was one of contention and debate across the nation and in Louisville.

First published in the Louisville German press, the Anzeiger, the Louisville Platform was widely distributed to and reprinted in German-language newspapers across the country. Quickly accompanied by replicates of its message, Heinzen's proclamation created a jealous feud among forty-eighters associated with the radical. Should an organization of free Germans truly have been formed, these community leaders wished to receive credit for crafting the doctrine for such a group. The editor himself contributed to this competition when he "attacked a comparable

\footnotetext{
${ }^{40}$ John E. Kleber, "German Radicalism and the Forty-Eighters," in German Influences in Louisville.C. Robert Ullrich and Victoria A. Ullrich, eds. (Charleston: The History Press,2019): 20.

${ }^{41}$ Kleber, "German Radicalism and the Forty-Eighters," 20.
} 
declaration of principles issued by the "Free Germans of Ohio"” at around the same time. ${ }^{42}$ Such hostility between forty-eighters was proof that much of the animosity that stemmed from the outcome of the Revolutions of 1848 had not dissolved during their exile in the United States.

Though Heinzen spent less than a year in Louisville, his mark on local groups and the well-known Platform that he composed remained in the minds and shaped the lives of many throughout the city, in positive and negative ways. The National Central Union of Free Germans, the Bund Freier Männer, and the Bund Freier Frauen continued to play a local political and cultural role even after Heinzen left in 1854. The bold words of the Louisville Platform had instilled a strong confidence in the politically-engaged German working class. Even for religious institutions, local hostilities had left them defensive of their communities and culture.

In the next section, the rise of nativism in the early 1850 s will be analyzed as it grew to dedicate more attention to the immigrant population of the United States, mainly for their religious differences and contentious political stances. It is important to note the origins of the Know-Nothing party's sudden rise to popularity corresponded to the years that German radicalism experienced a steady increase in support and notoriety. Both sides had their own interpretations of the American Republic, and who deserved to participate. This analysis of the Know-Nothing party's prominence then narrows to focus on the rise of nativism in Louisville, the harsh reaction to the Platform, its composers and supporters, and lastly, the increasing violence from those resentful of local immigrant activism.

\section{New Enemies Amid the Rise of Nativism}

By 1853 , radical forty-eighters had discovered a fitting role for themselves as reformers within German communities, organizations, and newspapers. Awareness of their efforts within

\footnotetext{
${ }^{42}$ Wittke, Against the Current, 95.
} 
these enclaves eventually spread to native citizens, who had noticed the increasing numbers, size, and significant working-class mobilization in immigrant neighborhoods. John Jentz explains that in these organizations, forty-eighters undoubtedly "played a catalytic role because of their energy...and cultural achievements." 43 Yet as their platforms gained more attention and moved to controversial domestic agendas like abolishing slavery, forty-eighters inadvertently made themselves and their immigrant brethren targets in the eyes of the emerging anti-foreigner, antiCatholic, unionist Know-Nothing party.

As Frank Towers explains, urban spaces were sites of real discord throughout the South, contradicting a long-dominant picture of the region as thoroughly agrarian and sympathetic to the planter class. Though Towers maintains a focus on New Orleans, Baltimore, and St. Louis in his study, nearly all more heavily-populated Southern towns became the homes of working-class native contempt toward the competition between slavery and free labor. ${ }^{44}$ This resentment was shared by immigrant populations, though Anglo workers equally blamed the foreign-born element of their cities for driving down local wages. A Southern branch of the proud, nativist party thus emerged from these frustrations. For border states like Kentucky in particular, increasingly loud advocates among the immigrant population against slavery also created political turmoil within these Southern cities.

Several developments aided in the rise of the Know-Nothing party by 1854 . The decline of the Whigs and subsequent rise of an emerging Republican party—with its anti-slavery views - frightened many figures living in border states on the maintenance of peace and

\footnotetext{
43 John B. Jentz, "The 48ers and the Politics of the German Labor Movement in Chicago during the Civil War Era: Community Formation and the Rise of a Labor Press," in The German-American Radical Press: The Shaping of a Left Political Culture, 1850-1940. Elliott Shore, Ken Fones-Wolf, and James P. Danky, eds. (Urbana: University of Illinois, 1992): 50.

${ }^{44}$ Frank Towers, The Urban South and the Coming of the Civil War. (Charlottesville: University of Virginia Press, 2004): 37.
} 
economic partnerships between the North and South. Increased immigration to this region by opinionated Germans especially threatened the accepted public political positions of the day, and theirs and their allies' bold abolitionist views proved controversial. Many immigrant groups did not attempt to hide their disgust for the Kansas-Nebraska Act of 1854, as they dreamed of settlements out West remaining free from the competition of slavery. As such, the KnowNothing party — a group which sought to preserve the Union by whatever means necessaryvilified groups of foreign-born in their own communities. For example, antislavery and proslavery nativists both viewed German immigrants as threats to the stability of their Republic, antislavery nativists condemned Germans for inflaming US politics and proslavery nativists blamed Germans for free-soilism in Missouri. ${ }^{45}$

The front page of the American Patriot newspaper, shown at the end of the chapter in Figure 8, depicts the platform of the Know-Nothing party in word and image as it disparages its enemies through imagery. It lists that the nativist party supports measures such as a defense of Anglo labor in the face of cheap immigrant work forces, as well as the idea that immigrants should reside in the United States twenty-one years before they were granted the ability to vote. In addition, the Know-Nothing party adamantly declared its distaste for Catholicism and supporting immigrant populations in any way. Their aversion to immigrant radicalism is best seen in the drawing above those declarations. On the left, nativist supporters defend their interpretations of democracy and republicanism in an orderly and patriotic fashion. To their right, immigrants who have just arrived angrily and perhaps even drunkenly espouse their loyalty to the Pope as well as radicalism. The ultimate parallel between the two parties is clear; one stands for order and American values, while the other is foreign and threatens to destroy those treasured morals.

45 See Anderson, Abolitionizing Missouri. 
Throughout the 1850s - a decade in which the Know-Nothings witnessed their largest and only electoral successes — forty-eighters combated nativist attacks on immigrant communities, creating a situation in which their radical moves and messages to defend themselves and their constituency against intolerance only further infuriated proponents of the Know-Nothing party across the country. As politicians were elected and laws passed that combated traditional practices in these immigrant neighborhoods, Jentz explains that Germans "looked for the leadership that the forty-eighters provided" in the face of discriminatory measures. $^{46}$

Gradually, as forty-eighters' initial motives for residing in the United States were supplanted by challenges that their fellow Germans faced as a singled-out population in the country. The effects of nativism's popularity grew pronounced as sabbatarianism, blue laws, and temperance movements won victory upon victory across the country. In addition to the prevalence of the Know-Nothing party as well as the presence of slavery in the "Promised Land" of democracy, Wittke argues that "the aggressive spirit of the refugees" in combating such issues solidified German resistance to assimilation. ${ }^{47}$ Considering the Puritan lifestyles of native citizens as "inferior," forty-eighters encouraged "cultural isolation" and declared German communities - with their social and labor organizations - to be decades ahead in terms of civility and democratic progress. ${ }^{48}$

Nativists identified Germans and other immigrants as sources for drunkenness, crime, poverty, and epidemics throughout many cities. The formation of numerous organizations in their communities cemented nativist opinion that these immigrants "refused to shed their

\footnotetext{
${ }^{46}$ Jentz, "The 48ers and the Politics of the German Labor Movement," 50.

${ }^{47}$ Carl Wittke, "The German Forty-Eighters in America: A Centennial Appraisal." The American Historical Review 53, no. 4 (1948): 714.

${ }^{48}$ Wittke, "The German Forty-Eighters in America," 715.
} 
European social identity." ${ }^{49}$ As President of the Know-Nothing party in Ohio, Thomas Spooner condemned German militia groups that exhibited the red flag of revolution rather than the American flag. ${ }^{50}$ The New York Express, a newspaper with Know-Nothing sympathies, criticized the democratic ignorance of these new immigrants, pointing out that "government is a science...which an Irishman, who cannot read, or a German, who knows not our language, customs, and traditions, cannot learn in a single day." ${ }^{51}$

These opinions influenced voting practices; the Know-Nothing party used its popularity to pass measures preventing immigrants from the vote. In 1853, efforts to amend voting laws so that immigrants had to reside in the United States for twenty-one years before they could vote failed to pass in many state legislatures, though laws restricting immigrants from voting for several years after their arrival succeeded in numerous states. Carl Berthold of St. Louis wrote to his family that "they wanted to treat the Germans unfairly.... They were supposed to have to wait to become citizens until they'd been in the country for twenty-one years, that's almost like it is in Germany with the princes, they want to rule over the Germans like that, but they got their necks broken." ${ }^{\prime 2}$ In 1855, Martin Weitz wrote to his family that "the Jenkeamerikaner (Yankees), they call themselves Know-Nothing yankees, they want to have control, but democracy wins," yet that if tensions continued to escalate over such matters, "a revolution" would result. ${ }^{53}$ Weitz's usage of the word "revolution" supports the idea that the European

\footnotetext{
${ }^{49}$ Ira M. Leonard and Robert D. Parmet, American Nativism, 1830-1860. (New York City: Van Nostrand Reinhold Company, 1971): 53.

50 Tyler Anbinder, Nativism and Slavery: The Northern Know-Nothings and the Politics of the 1850s. (New York: Oxford University Press, 1992): 118.

${ }^{51}$ Anbinder, Nativism and Slavery, 118.

52 Carl Berthold, "St. Louis, February 2, 1853," in News from the Land of Freedom: German Immigrants Write Home. Walter D. Kamphoefner, Wolfgang Helbich, and Ulrike Sommer, eds. (Ithaca: Cornell University Press, 1988): 325 .

53 Martin Weitz, "Rockville, July 29, 1855," in News from the Land of Freedom: German Immigrants Write Home. Walter D. Kamphoefner, Wolfgang Helbich, and Ulrike Sommer, eds. (Ithaca: Cornell University Press, 1988): 346.
} 
uprisings of 1848 and 1849 remained relevant in the minds of politically-active working-class German immigrants.

Know-Nothing politicians had more than one mechanism to weaken immigrant influence in the United States. One of the most strategic political maneuvers demonstrated by the KnowNothings to protest the immigrant lack of assimilation regarding drinking practices and language was their alliance with the temperance movement. Both groups emphasized through their press the stereotype of the "German affinity for beer and Irish for whiskey." 54 As more laws were passed restricting the consumption of alcohol or complicating the establishment of saloons and taverns, Levine argues, the more offended immigrant populations became toward what they considered "gratuitous pieces of class discrimination." 55

The Chicago Lager Beer Riot in 1855, an image of one of the beer halls that experienced violence is seen in Figure 9 at the end of the chapter, is a revealing example of growing resentment toward these "violations of personal liberty" and the confrontations that could arise if provoked long enough. ${ }^{56}$ The passage of alcohol regulations and the arrest of those who violated such legislation resulted in a clash between the German community and police. Out of anger toward the jailing of several Lokal (bar) owners, German protesters "kept the city in a virtual state of siege for four days. ${ }^{{ }^{57}}$ Nativist representatives in Pennsylvania passed an expensive license bill for beer as well as a Sunday closing law went largely ignored in German and Irish neighborhoods. In 1854, Philadelphia's mayor, recognizing that the police forces in these communities mainly consisted of immigrants seemingly opposed to such regulations, fired all

\footnotetext{
${ }^{54}$ Leonard and Parmet, American Nativism, 89.

${ }^{55}$ Bruce Levine, The Spirit of 1848: German Immigrants, Labor Conflict, and the Coming of the Civil War. (Urbana: University of Illinois Press, 1992):89-90.

${ }^{56}$ Levine, The Spirit of $1848,90$.

${ }^{57}$ Ibid.
} 
non-native officers and replaced those forces with native-born citizens. ${ }^{58}$ Germans and other immigrant populations targeted for exaggerated drinking habits resented extreme measures to control their behavior.

Beyond drinking traditions, another German pastime defied sabbatarian laws. ${ }^{59}$ Sunday leisurely activities within German neighborhoods provoked one native citizen of Cincinnati to comment in 1854 that Germans "have succeeded in practically abolishing the Sabbath, as they virtually ignore that divine institution even as a day of rest, keeping their stores open the whole day." ${ }^{00}$ Know-Nothing politicians would not acknowledge that working-class neighborhoods failed to adhere to sabbatarian laws because there was literally no other non-work day to engage in recreational activities and spend time with family and friends.

The tenacity of immigrant communities to retain their native tongue aggravated KnowNothing writers who believed that corrupt values and practices tied to language prevented assimilation. Although Germans only made up four percent of the United States' population by 1860, a majority of these 1.3 million people conglomerated in enclaves, in which German remained the dominant language of speaking, writing, and everyday commerce.$^{61}$ The rising population of these neighborhoods, explains Tyler Anbinder, threatened to outnumber nearby areas in which mainly native citizens resided. ${ }^{62}$ According to James Bergquist, these sites fortified "the pervasive "foreignness' of the district" in the eyes of Know-Nothings. ${ }^{63}$ In 1846 ,

\footnotetext{
${ }^{58}$ Anbinder, Nativism and Slavery, 143.

${ }^{59}$ Levine, The Spirit of $1848,10$.

${ }^{60}$ Steven Ross, Workers on the Edge: Work, Leisure, and Politics in Industrializing Cincinnati, 1788-1890. (New York: Columbia University Press, 1985):174.

${ }^{61}$ Levine, The Spirit of 1848, 58.

${ }^{62}$ Anbinder, Nativism and Slavery, 8.

63 James Bergquist, "German Communities in American Cities: An Interpretation of the Nineteenth-Century Experience," Journal of American Ethnic History 4, no. 1 (1984): 9. See also Marion L. Huffines, "LanguageMaintenance Efforts Among German Immigrants and Their Descendants in the United States," in America and the Germans, Vol. 1: An Assessment of a Three-Hundred Year History. Frank Trommler and Joseph McVeigh, eds. (Philadelphia: University of Pennsylvania Press, 1985): 247.
} 
London's Chambers' Edinburgh Journal commented that the goal of every German immigrant family was "to fix itself as near as possible to its relatives.... Every settlement thus becomes the nucleus of a pure German circle, which is born, marries, and dies within itself, and with the least possible admixture of Anglo-Americans." ${ }^{94}$ Some nativist-controlled legislatures went so far as to regulate public schools located in German communities, dominated by German speakers, forbidding the use of their native tongue. In Wisconsin, a state to which many Germans immigrated, an 1854 bill passed that restricted any other language besides English as the language of instruction in public schools.

The German and Irish working class certainly shared with Anglo-American laborers common economic struggles for representation and organization. Their occasional collaboration for reform has been noted. In the 1850s, however, a substantial portion of the Know-Nothing voting bloc was composed of native-born working-class Americans who, according to Ross, feared job competition with the "mass influx of immigrants" arriving to the United States during those years. ${ }^{65}$ Mass reorganization of the manufacturing sector by the growth of factories and poor wages were considered secondary to the threat presented by newcomers, many of whom protested more candidly than others regarding the unfairness of the economic system.

Know-Nothing representatives had stressed this working-class animosity since the founding of the party. In 1846, New York Congressman W.W. Campbell spoke before the House of Representatives on behalf of native-born laborers, who "feel already this fearful competition which now meets them at every turn, and which may...reduce them to the condition of their

\footnotetext{
${ }^{64}$ Stanley Feldstein and Lawrence Costello, comps. "German Emigration," Chambers Edinburgh Journal, June 20, 1846, 389. In The Ordeal of Assimilation: A Documentary History of the White Working Class. (Garden City, NY: Anchor Press, 1974.

${ }^{65}$ Ross, Workers on the Edge, 184.
} 
European competitors." ${ }^{" 66} \mathrm{He}$ continued, warning that "the labor of our native citizens will not meet its just reward, so long as we give equal...encouragement to the vast foreign swarms" coming into the United States. ${ }^{67}$ Even over a decade later, proponents of the Know-Nothing platform remained committed to antagonizing European workers and their activism, proclaiming in one platform that "Americans only shall govern America." 68

It proved lucrative for American politicians in this particular decade to call attention to the increasing numbers in immigrant communities, as well as to cast blame for some of the population's moral transgressions as influenced by the activities of politically or socially active foreigners. Oscar Handlin points out that it was not specifically anti-immigrant or anti-Catholic sentiment responsible for these attacks on entire ethnic groups, but rather that targeting a particular population served as "an instinctive rallying point around which a nation in distress could temporarily draw together." ${ }^{69}$ The divisive issue of slavery posed momentous repercussions for the preservation of the country as it existed at the time. Among other figures, outspoken leaders among the German community inevitably garnered controversy with their calls for economic, social, and political reform.

In only a few years, outspoken forty-eighters "had introduced disturbing amendments to the legacy of 1776," and criticized glorified preconceptions of American democracy out of support for their "collectivization of workers and...the abolition of slavery." 70 Proponents of the Know-Nothing party and other nativists increasingly called attention to what they considered a

\footnotetext{
66 "W.W. Campbell, New York Congressman, before the House of Representatives, April 8, 1846," in American Nativism, 1830-1860. (New York City: Van Nostrand Reinhold Company, 1971): 620. Originally published in Congressional Globe, 29th Congress, 1st Sessions, Appendix, pp. 620-621.

67 "W.W. Campbell," 620.

68 "Platform of the Principles of the American Party in Connecticut, adopted June 28th, 1855," in American Nativism, 1830-1860. (New York City: Van Nostrand Reinhold Company, 1971): 144.

69 Oscar Handlin, "The American Scene," in The Forty-Eighters: Political Refugees of the European Revolution of 1848. A.E. Zucker, ed. (New York: Columbia University Press, 1950): 41.

${ }^{70}$ Fleche, The Revolution of 1861, 36.
} 
disruption of peace through the introduction of "Red Republicans [and]...infidels...bequeathed to the United States in the form of refugees." ${ }^{71}$ Know-Nothing newspapers raised concerns that it was only a matter of time before forty-eighter-supported organizations incited "riots and...revolutions" in their new homeland, agitating the fragile union with their uncompromising rhetoric. ${ }^{72}$ Due to unprecedented activity within their communities as well as the radical positions of their leaders, the German immigrant population had never before garnered so much hostile attention and their infamy in the eyes of the nativist movement only led to tragic consequences in the course of the 1850 s.

\section{Forty-Eighters in a Know-Nothing State}

In a border-state like Kentucky, the contentious positions of forty-eighters and other German activists placed pressure on a population already split over slavery and economic reform. Nativism and the Know-Nothing movement accumulated widespread popularity in the state and its largest city, Louisville. The arrival of radical revolutionary figures like Karl Heinzen, his Louisville Platform, and other activities within the German working-class community drew undesirable attention to the entire population of Germantown. Large numbers of Germans who had only settled in the region by the mid-1850s exacerbated the presence of foreigners. ${ }^{73}$ By 1855 , almost half of Louisville's sixty thousand inhabitants had not been born in the United States. As their communities strengthened and organized, nativist awareness of Germans and Irish immigrants as well as their controversial beliefs increased. ${ }^{74}$

\footnotetext{
${ }^{71}$ Ibid.

72 Ibid.

${ }^{73}$ Matthew Salafia. Slavery's Borderland: Freedom and Bondage along the Ohio River. (Philadelphia: University of Pennsylvania Press, 2013): 243.

74 James S. Ramage. Kentucky Rising: Democracy, Slavery, and Culture from the Early Republic to the Civil War. (Lexington: University of Kentucky Press, 2011): 160.
} 
The tendency to respond to negative attention resulted in what Kathleen Conzen refers to as "ethnic separatism," when immigrants formed practically entirely autonomous colonies of German speakers in different cities including Louisville. ${ }^{75}$ Reaction related to the organization of local Germans heightened in negativity around 1853, upon the arrival of Heinzen himself, when famed editor George Prentice of the widely-read Louisville Journal announced the "the head of the labor union in the city was a German revolutionist." ${ }^{" 76}$ A staunch unionist at the time, Prentice placed himself in the Know-Nothing camp upon the dissolution of the Whig party. In large part due to the supportive rhetoric published in his newspaper, the nativist group's membership in Kentucky had risen to 50,000 by the tumultuous election year of $1855 .{ }^{77}$ Wittke explains that the "lodges and societies" of German communities now appeared "anti-Christian" in the minds of local and outspoken nativists like Prentice. ${ }^{78}$ Even German-owned breweries in the town were targeted by temperance groups of the city, and one would suffer destruction at the hands of an angry nativist mob in August of $1855 .{ }^{79}$

To combat these incessant attacks against members of their community, German editors of all ideological backgrounds "found themselves in a defensive position," protecting their rights to freedom of expression. ${ }^{80}$ Constant threats, argues John Hawgood, provoked them to "political agitation, to party maneuvers, to platforms, to demonstrations, and to threats," to defend their

\footnotetext{
${ }^{75}$ Kathleen Conzen, "German-Americans and the Invention of Ethnicity," in America and the Germans: An Assessment of a Three-Hundred Year History, vol. 1. Frank Trommler and Joseph McVeigh, eds. (Philadelphia: University of Pennsylvania Press, 1985): 137.

${ }^{76}$ Sister Agnes McGann, Nativism in Kentucky to 1860. (Washington, D.C.: Catholic University Press, 1944): 62.

77 Philip W. Kennedy, "The Know-Nothing Movement in Kentucky: Role of M.J. Spalding, Catholic Bishop of Louisville.” Filson Club Historical Quarterly 38, 1964: 21.

${ }^{78}$ Wittke, Refugees of Revolution, 182.

${ }^{79}$ Conrad D. Selle and Peter R. Guetig, "Breweries," in Germans in Louisville: A History. C. Robert Ullrich and Victoria A. Ullrich, eds. (Charleston, S.C.: The History Press, 2015): 90.

${ }^{80}$ Lawrence S. Thompson and Frank X. Baum, "The Forty-Eighters in Politics," in The Forty-Eighters: Political Refugees of the German Revolution of 1848. A.E. Zucker, ed. (New York: Columbia University Press, 1950): 116.
} 
neighborhoods solidify their positions as leaders in those communities. ${ }^{81}$ Indeed, Hawgood offers the creation of Heinzen's Bund Freier Männer, or Union of Free Men, as an example of this type of protective, immigrant organization. ${ }^{82}$

Heinzen would later comment that the Know-Nothings of the 1850s tried in vain to transform immigrants into Be-Nothings, who assimilated fully to the American ways of life. Charlotte Brancaforte explains that, according to the radical forty-eighter, memories and experiences of one's homeland subsequently stimulated strategies for potential change and reform in one's adopted homeland. As a result, forty-eighter Germans challenged what many viewed as the prudish standard of proper American living and pushed for the eradication of remaining obstacles like slavery to the fulfillment of true democracy. ${ }^{83}$ During his short yet meaningful time in Louisville, Heinzen expressed such beliefs in the Louisville Platform and in the city's Turnverein, the members of which unapologetically voiced their views on especially controversial issues for the region. In 1855, the "Platform of the Turnerbund" was published and stated that "slavery, nativism, and prohibition" proved the "worst abuses of the time" and cemented their hatred for the nativist group by proclaiming that "the Turner will vote for no man who is a member of the Know-Nothing party." 84

Once the Louisville Platform had been translated so that English speakers could take in its radical message and utter disdain for the nativist party, more controversy ensued. The conservative Baltimore Sun announced that "a German Reform party has started...at Louisville, Kentucky," adding bitterly that it "seems to have taken upon itself the task of instructing the

\footnotetext{
81 John A. Hawgood, The Tragedy of German-America: The Germans in the United States of America during the Nineteenth Century, and After. (New York City: G.P. Putnam's Sons, 1940): 232.

${ }^{82}$ Hawgood, The Tragedy of German-America, 233.

${ }^{83}$ Charlotte Lang Brancaforte, The German Forty-Eighters in the United States. (New York: Peter Lang, 1989): 284.

${ }^{84}$ Augustus J. Prahl, "The Turner," in The Forty-Eighters: Political Refugees of the European Revolution of 1848.

A.E. Zucker, ed. (New York City: Columbia University Press, 1950): 100.
} 
native population upon their duties as citizens and to alter and amend all our institutions." 85 The newspaper then added that "the attempt to enforce" the laws laid out in the Platform "would produce the most determined opposition from our citizens than any party ever met in this country." 86 Despite the Sun's condemnation, the paper spread further awareness to Heinzen's ideas by explaining them in detail while demonizing its messages. Other papers did this, as well. The National Intelligencer of Washington, D.C., provided a summary of the Platform's contents, also referring to Heinzen's group in Louisville as a new "German party." 87 The Boston Liberator, by contrast, applauded the Platform's adoption among liberal German groups from New Albany, Indiana to the United German Societies of Boston. ${ }^{88}$

Samuel C. Busey of Washington, D.C., an outspoken leader in the short-lived Native American Party, called the Platform "antagonistic to the fundamental principles and established usages of the government," urging that the "masses" should not be trusted to determine the correct role of government. ${ }^{89}$ In addition, John P. Sanderson of the Daily News in Philadelphia warned potential American sympathizers that the radical German writers of the Louisville Platform had "brought obloquy upon the very name of republicanism in Europe" due to their "ultra, wild, and visionary schemes and theories" before immigrating to the country. ${ }^{90}$ An examination of the Louisville Platform and the scathing remarks of its opponents illustrates well the different interpretations of republicanism that the immigrants transported from the German Confederation and US understandings of the term.

\footnotetext{
85 “Louisville, KY," Baltimore Sun, April 25, 1854.

86 "Louisville, KY," Baltimore Sun, 1854.

87 “German Party," National Intelligencer, April 27, 1854.

88 "Legislative Acts and Legal Proceedings," Boston Liberator, April 7, 1854.

${ }^{89}$ Levine, The Spirit of 1848, 108.

${ }^{90}$ Ibid.
} 
The composers of the Platform may have experienced a positive reception in some English-speaking circles, but the overwhelming reaction was deep admonishment of the proclamation as an existential threat to the United States. The Western Citizen of Paris, Kentucky, accused the composers of the Platform to be "jacobins" attempting to "take the place of a rational system...under which all classes have prospered." 91 Closer to home, the Louisville Times called the Germans responsible for the proclamation "infidels" who should not consider themselves relevant enough "to dictate to native-born Americans what they should do" to improve their country. ${ }^{92}$ The Louisville Daily Courier reported that "some person or another, for political purposes, desired to build up for an approaching Presidential election a new party--a German party. ${ }^{93}$ It also accused that the composers of the Platform would "present such men as Clay, Webster, and Calhoun, from becoming President." 94 Such reaction on the part of KnowNothing supporters or sympathizers reflects that nativists understood these immigrant-led movements as a direct confrontation and affront to the Know-Nothing party and its success in future elections at all levels.

Even facial hair became symbolic of dangerous radicalism in nativist circles. In September of 1854, the Louisville Daily Courier provided a physical description of these enemies of the Know-Nothing party, and instructed readers to keep watch for such figures on the streets. They remarked that almost all of them sported beards, "a garden of veriest fantastic notions and beliefs." 95 Calling out Germans specifically, the newspaper complained that "how is it every German exile we meet sports a monstrous beard?"96 This appearance they placed in

\footnotetext{
${ }^{91} \mathrm{McGann}, 65$. Originally published in the Western Citizen, July 27, 1855.

${ }^{92} \mathrm{Ibid}, 66$.

${ }^{93}$ Louisville Daily Courier, Wednesday, April 26, 1854, 2.

${ }^{94}$ Ibid.

${ }^{95}$ Ibid, Friday, September 22, 1854, 3.

${ }^{96}$ Ibid.
} 
direct contrast to the Know-Nothing supporter, who kept a clean-shaven face. They explained that "now conservatism is marked by the cleanest faces." ${ }^{97}$ Therefore, unkempt hair is "a true index to the sentiment within." ${ }^{" 98}$ Clearly, Heinzen, with his own beard and disheveled appearance, fit the image of the dangerous radical causing mischief in the heart of the United States.

Certainly, the Louisville Platform was neither the first nor the last controversial document published by idealistic forty-eighters, yet it earned the wrath of hundreds of nativists and their newspaper outlets like nothing else that had come before it. Not even the group of radicals in Wheeling, Virginia, who hosted a "Congress of German Revolutionists" in honor of Louis Kossuth in 1852 and proclaimed similar opinions to the Louisville Platform, had garnered such notoriety—positive and negative—-for their actions. ${ }^{99}$ Upon reflection, Heinzen wrote in Erlebtes that the Platform's position over slavery proved the most controversial part of the document as a whole. ${ }^{100}$ This is not surprising, given the contentious environment of 1854 as well as the fact that to be an abolitionist or express abolitionist views was extremely taboo at that time in Kentucky.

Know-Nothing city governments escalated their attacks against German organizations, suspecting them of harboring radical and perhaps even revolutionary aspirations. Cincinnati and Boston forced the dissolution of German militias and New York City rejected the licensing of a local Turnverein, accusing the organization of being an "anarchist society in disguise."101

\footnotetext{
${ }^{97}$ Ibid.

${ }^{98}$ Ibid.

${ }^{99}$ Ken Fones-Wolf, "Caught Between Revolutions: Wheeling Germans in the Civil War Era," in Transnational West Virginia: Ethnic Communities and Economic Change, 1840-1940. Ken Fones-Wolf and Ronald L. Lewis, eds. (Morgantown, WV: West Virginia University Press, 2011): 25.

${ }^{100}$ Heinzen, Erlebtes, 502.

${ }^{101}$ Wittke, Refugees of Revolution: The German Forty-Eighters in America. (Philadelphia: University of Pennsylvania Press, 1952):185.
} 
Nativist newspapers went after the German population as a whole, accusing them of "driving 'white people' out of the labor market," and denounced recreational customs, as "forcing Americans to accept a lower standard of living" by driving down wages. ${ }^{102}$ Others described Germans as a race below that of Anglos but slightly above the black slave. ${ }^{103}$ Even popular singing societies were identified as "the perpetuation of foreign clannishness." 104 Germanlanguage newspapers, too, were targeted not only as obstacles to assimilation but, most importantly, as mouthpieces for radicalization. Not even Carl Schurz, the most attractive German immigrant and forty-eighter in the eyes of American politics, could sway opinion when he defended the German press as necessary, for "it fulfills a real and very urgent want."105

German defiance in the wake of such aggressive attacks only fanned the flame of nativist abhorrence in regard to their communities and ways of life. In 1855, an eruption of violent confrontations in the United States between Know-Nothing gangs and defenders of ethnic neighborhoods alarmed the nation. Certainly, riots of a similar nature had occurred throughout the country for years. In 1852, a fight broke out between Germans and nativists when the latter threw rocks into the windows of the Anzeiger des Westens, St. Louis' most popular foreignlanguage newspaper. German militias were ambushed by Know-Nothing gangs in 1853 while performing a military drill in New Orleans. ${ }^{106}$ During a Philadelphia Turnfest in 1854, a German singing society was attacked by police for "disturbing the peace."107

Though unsettling, these confrontations did not compare to the violent clashes of 1855 in Cincinnati and, eventually and most tragically, in Louisville. Though injuries were common,

\footnotetext{
${ }^{102}$ Ibid.

${ }^{103}$ Ibid, 182.

${ }^{104}$ Ibid, 185.

105 Feldstein and Costello, comps. "The Reminiscences of Carl Schurz," by Carl Schurz, 3rd edition (New York, 1908), 257.

${ }^{106}$ Wittke, Refugees of Revolution, 187. Originally published in the Cleveland Wächter am Erie, May 4, 1853.

107 Ibid.
} 
deaths had been infrequent during these brutal encounters. Some of the most radical of fortyeighters had made their headquarters in Louisville, Cincinnati and Columbus and all three experienced violence in their German communities. In Columbus, Ohio, the local Turnverein, singing society, and militia were targeted with rocks and bullets, leaving several wounded and one person dead. These confrontations proved frightening enough for the city's Germans that they refused to hold any kind of public celebration until 1859, yet contributions from German organizations and Turnverein across the country poured in to help with medical bills and court payments for their beleaguered countrymen. ${ }^{108}$

Perhaps events in Cincinnati's "Over-the-Rhine" district in the spring of 1855 provided the clearest warning for what was to come a few months later for the German community in Louisville, as shown in Figure 10. When Know-Nothing members prevented the foreign-born from voting in a city election, the city's Turner group "threw up barricades and mobilized their sharpshooters to protect the German section" in a manner that reminded many of the battles fought in Paris, Vienna, Berlin, as well as Baden throughout the Revolutions of 1848 and 1849. ${ }^{109}$ Wittke describes that "the files of the German-language press bulge with accounts of the controversy between nativists and foreigners from 1854 to the end of the decade," when only the outbreak of the American Civil War could distract German communities from their KnowNothing enemies. ${ }^{110}$

To add insult to injury, the Illinois Staatszeiting called attention to "the unjust dismissals of foreigners from public offices." 111 New York City's Neue Zeit criticized the hypocrisy of the lack of media coverage on these attacks, remarking that "if one hair is hurt on the head of an

\footnotetext{
${ }^{108}$ Ibid. Originally published in the Columbus Westbote, July 6, 13, 27, 1855.

109 Ibid. Originally published in the Columbus Westbote, April 6, 1855.

${ }^{110} \mathrm{Ibid}, 188$.

${ }^{111}$ Ibid, 189. Originally published in the Chicago Illinois Staatszeiting, Oct. 26, 1853.
} 
abolitionist in Kansas, the 'humane' press of the free states teems with lead articles" but a dead German or Irishman earned "not a single word."112 Even back in the German Confederation, newspapers actively covered the persecution of German immigrants by nativists.

Meanwhile in Louisville, nativists spread the word that these ethnic-based groups, such as the "National Central Union of Free Germans," or Bund Freier Männer, consisted of the worst type of immigrant, namely the radical revolutionary. In contradiction to this accusation, KnowNothing sympathizers also accused that the local German population "served to strengthen the (Catholic) Church," as a higher proportion of Louisville Germans practiced Catholicism. ${ }^{113}$ In other words, Germans were either too anti-religious or socialist in their fight for workers' rights and progressive reform, or too Catholic and spiritually dedicated to a universal, anti-American power. Negative attention from the nativists haunted Germans in Louisville throughout the 1850s. Catholic bishops' calling on increasing numbers within their congregations to combat nativism only heightened anxieties, as it seemed to prove that both immigrant groups had united behind their common hatred of nativism. By 1855, the local Know-Nothing party grew adamant that politicized Germans as well as Irish Catholics should not have access to the vote, and in the next chapter their efforts to ensure that foreigners were restricted from the polls will be analyzed along with the events of Bloody Monday and its aftermath.

Perhaps Christian Lenz, a German resident of Louisville, described best the tense conditions leading up to the election day of 1855 in a letter back home to his family. In May of that year, he explained that "the Americans are rising up against the Germans with a strong hand" and goes on to claim "they don't want to let them vote and everywhere they want to beat

\footnotetext{
${ }^{112}$ Ibid, 188. Originally published in the Neue Zeit, 1855.

113 Charles Deusner, "The Know-Nothing Riots in Louisville." The Register of the Kentucky Historical Society 61 , no. 2 (1963): 126.
} 
and force them back." 114 In addition, Lenz comments that "it's the same all over America," and, most ominously, predicts that "soon a war will break out." ${ }^{115} \mathrm{He}$ followed up this remark with a refusal to send money for his brother's passage to the United States, arguing "do you think I should send someone travel money so his blood can flow?"116 Lenz's words capture the fear, intimidation, and anger experienced by Germans in the River City by 1855 .

114 Christian Lenz, "Louisville, May 29, 1855," in News from the Land of Freedom: German Immigrants Write Home. Walter D. Kamphoefner, Wolgang Helbich, and Ulrike Sommer, eds. (Ithaca: Cornell University Press, 1988): 133.

115 Lenz, News from the Land of Freedom, 133.

${ }^{116}$ Ibid. 


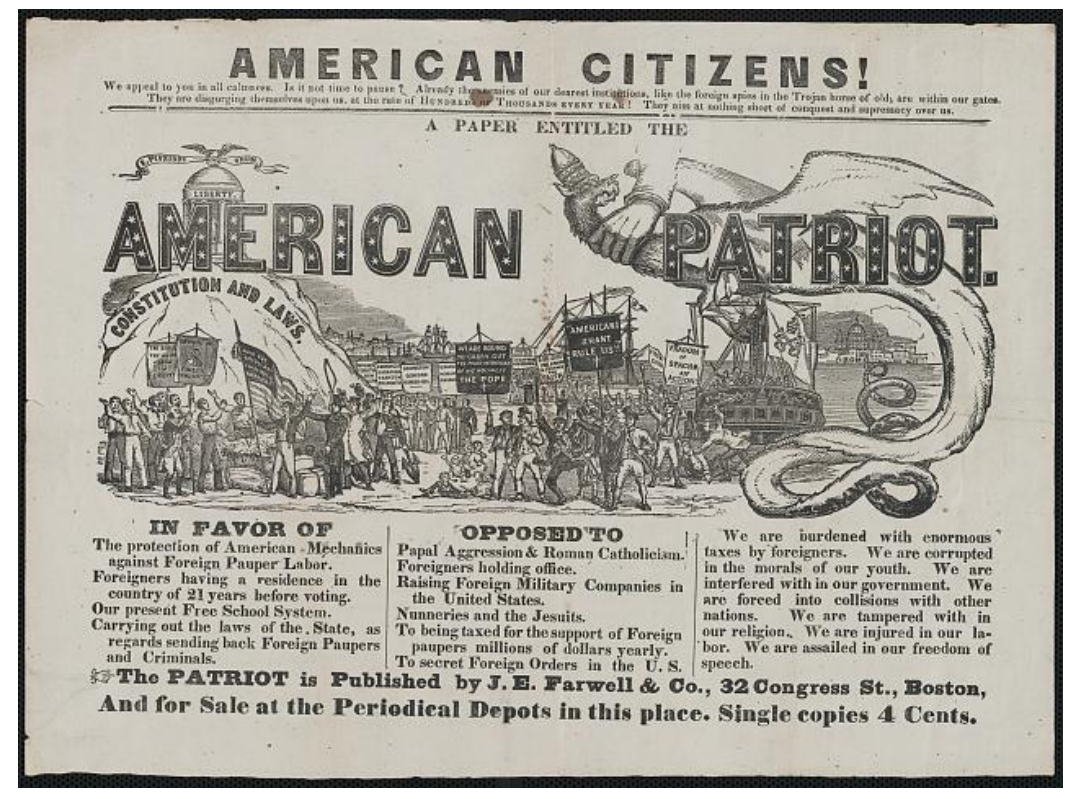

Figure 8: “A Paper Entitled the American Patriot,” 1852. Courtesy Library of Congress: Popular Graphic Arts Collection.

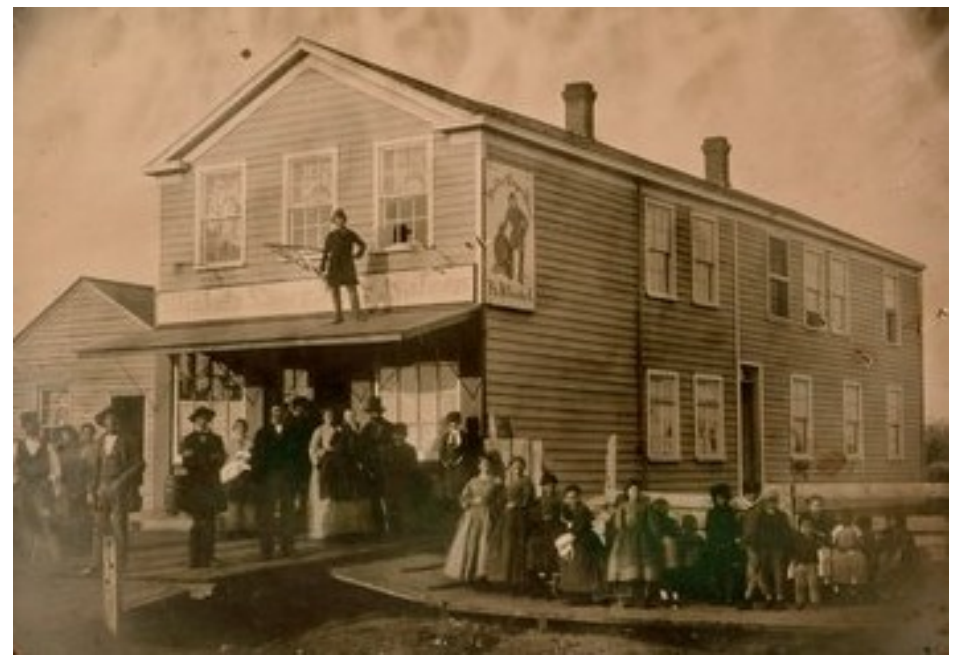

Figure 9: Henry Kinkel's Lager Beer Saloon. Courtesy Chicago Historical Society. 


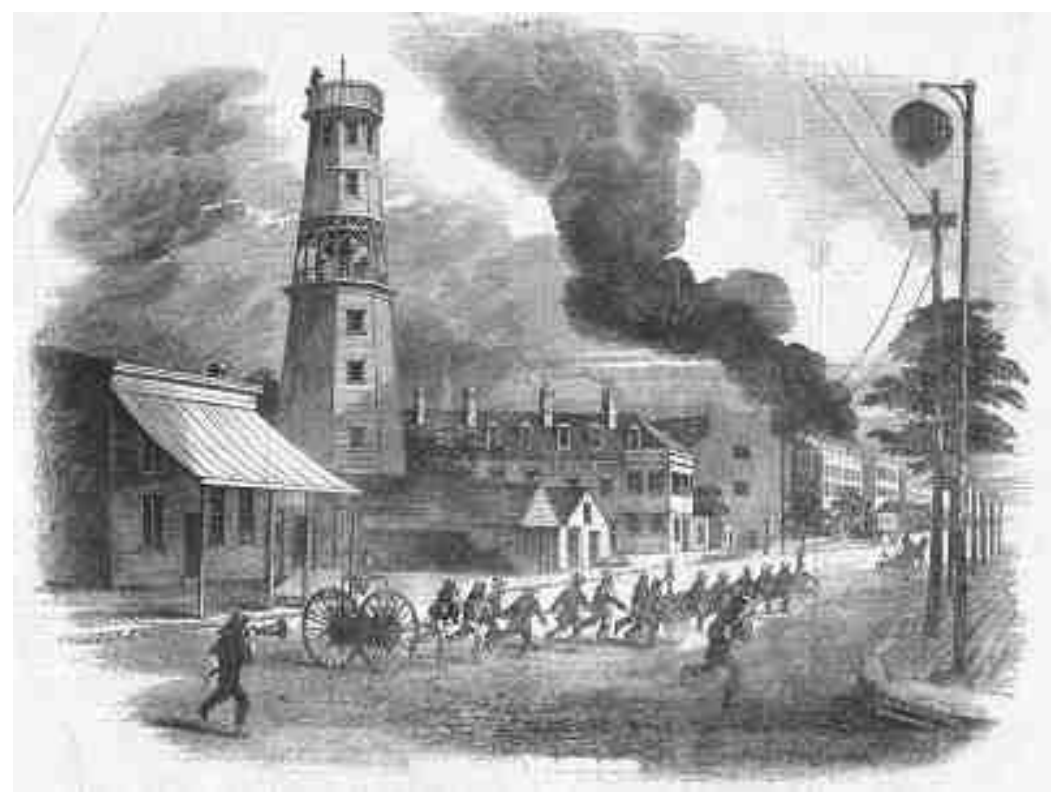

Figure 10: Cincinnati Riots of 1855. Courtesy Illustrated London News. 


\section{Chapter III: Rallying Rhetoric and Local Collisions of Republicanism}

Karl Heinzen departed Louisville in the fall of 1854, approximately six months after the release of his controversial Louisville Platform, though the ideas which he proclaimed in the document survived within affiliated groups in the city. Oddly, news of his departure was not reported until some months later in the Louisville Daily Courier, which wrote that Heinzen had "removed to New York. In that place he will resume the publication of his journal, which is a violent advocate of infidelity and all sorts of German radicalism." Nevertheless, the republican ideology and reforms that he espoused in the Louisville Platform, as well as other speeches and pamphlets, resonated with politically-charged immigrant groups. These radicals and foreign-born were left determined to vote and thus to exert their influence on American politics and society through the empowerment and civic involvement of local immigrant populations. Companions of Heinzen also remained committed to combating the blind fanaticism and intolerance of the rising Know-Nothing party, whose most notable voice pieces increased activism on the part of Louisville's immigrant communities with an obsessive and paranoid outcry.

Heinzen had hoped that German-Americans would form a new party to combat the rise of the Know-Nothings. If they did so, they had his permission to adopt the Louisville Platform as their Constitution, a document that he considered "the best antidote for Know-Nothingism."2 Regardless if these ambitious goals were achieved, Heinzen and other forty-eighters' passionate dislike for the nativist party—evident in documents like the Louisville Platform —encouraged ordinary German immigrants in medium-sized towns like Louisville to defend themselves against the Know-Nothing party's rising domination over local politics and their attacks on the city's foreign-born population.

${ }^{1}$ Louisville Daily Courier, Friday, June 29, 1855, 2.

${ }^{2}$ Carl Wittke, Against the Current: The Life of Karl Heinzen, 1809-80. (Chicago: University of Chicago Press, 1945): 289. 
Ordinary immigrants, labor activists, and Turners took up the local German community's cause where Heinzen had left it. They remained firmly loyal to their German-oriented groups and organizations, defended their reputations against Know-Nothing leaders, and even formed a defensive league called the Sag-Nichts to protect themselves from nativist violence. Despite the discriminatory policies and prejudiced politicians they faced at this time, the politicized German community remained dedicated to the cause of increased rights and liberties for immigrant populations. Forty-eighters as well as their allies and sympathizers proved willing to pay the price for their right to enfranchisement and, thus, to be treated as respected citizens.

This chapter introduces editor George D. Prentice, the most well-known opponent of immigrant rights in Louisville during this time (shown in Figure 11 at the end of the chapter). In his writing and speech, he had much in common with the fearless Heinzen--although the two could not have been farther apart in terms of political belief. A former Whig, Prentice found a comfortable second home in the rising Know-Nothing party, essentially transforming his Louisville Journal into a mouthpiece for the group's local branch. The second section of this chapter demonstrates the rising tensions in the city during this time, evident within the intense and brutal language used by nativist leaders like Prentice in reference to their foreign-born enemies. Quotes from his Louisville Journal throughout the year of 1855 are used to demonstrate such attitudes as well as to fully convey the extensive attempts made by the editor to intertwine the beliefs of all immigrant groups with Heinzen and his companion's radical vision.

In these editorials, Prentice focused almost exclusively on the German population as threats to the native-born citizenry nationwide as well as in local neighborhoods. In some instances, he directly admonished the Louisville Anzeiger, the city's most successful Germanlanguage newspaper. Quotes from its pages are unfortunately limited to secondary sources and 
their English translations, yet in criticizing, transcribing, and therefore exposing the beliefs of his enemies, Prentice provided a descriptive account of the reception that the newspaper received to its support of the Platform, relationship to Heinzen, and the groups with which he was affiliated during his time in Louisville. Due to their rallying cries on a notorious election day in the summer of 1855 , it is argued that the editors of the Anzeiger encouraged their audience to defend their rights with a subtle but easily understood reminder of the sacrifice that had been made in 1848 and 1849 in order to assert and claim their liberties in German lands.

The third part of this chapter begins with an account of that election day, or what has since been referred to as the "Bloody Monday" riots, indeed a clash between those who were deemed to support Heinzen's and other contemporary's radical worldviews and those who understood such ideas as threats to their Republic. Several primary accounts report the events of that day. To provide additional context and interpretation, secondary sources have been used to supplement certain details left out of contemporary narratives. The aftermath of the violence left such a nasty legacy that Prentice and the Know-Nothings immediately tried to deflect their responsibility by blaming the immigrants for the local carnage. Newspaper articles as well as testimonies gathered from supposedly trustworthy witnesses to the day's events are also utilized to convey such an environment of denial.

\section{Buildup to Bloody Monday: Prentice and the Anzeiger Appeal to Audiences}

On a spring day in 1849, the steamship Winfield Scott arrived in Louisville from New Orleans. From its steps disembarked more than four hundred German immigrants, a substantial addition to the pre-existing German population in the River City. ${ }^{3}$ Ludwig Stierlin, editor, radical

\footnotetext{
3 Thomas P. Baldwin, "The Public Image of Germans in Louisville and in Jefferson County, Kentucky, 1840-72." Yearbook of German-American Studies 29 (1994): 84.
} 
forty-eighter, and future historian of Louisville's German community, was one of these immigrants who arrived at the city's port (shown below in Figure 12). He later commented that "the steamer had packed the poor emigrants together like the pegs in the hood. Forty had died on the way and many died shortly before landing in New Albany," a dock located on the western side of the Ohio River. ${ }^{4}$ As Thomas Baldwin explains, arrival to Louisville by way of steamboat provided a dramatic view of the newcomers that settled in the river valley. ${ }^{5}$ Some established their own trades whereas others received laborious jobs on the docks. Stierlin soon joined the editing team of the liberal newspaper, the Louisville Anzeiger.

The rise in immigration to Louisville throughout the 1840s and into the 1850 s was significant. By 1850 , the city's population had increased to 43,217 , more than double the 21,000 people who resided there in $1840 .{ }^{6}$ Wallace Hutcheon adds that of those 43,217, 20,000 were Catholic, and 12,461 had been born in another country, meaning that one out of three residents of the city were immigrants. Germans consisted of the largest minority in this population, totaling 7,357, followed by the Irish at 3,105. Another 1,999 immigrants from other countries are included in this total, as well. ${ }^{7}$ As the presence of immigrants increased, so, too, did stereotypes that described typical characteristics of the foreign-born population. Not surprisingly, Charles Deusner writes, a larger proportion of those labeled as "paupers, criminals, deaf-and-dumb, and insane" were indeed immigrants. ${ }^{8}$ Migrants usually arrived with little resources and family to support them, therefore they often struggled financially in the beginning. Nativist spokesmen and

\footnotetext{
${ }^{4}$ Ludwig Stierlin, Der Staat und die Stadt Louisville unterbesonderer Berücksichtigung des deutschen Elementes. (Louisville: Louisville Anzeiger, 1873): 141.

${ }^{5}$ Baldwin, "The Public Image of Germans," 84.

${ }^{6}$ Ibid.

${ }^{7}$ Wallace Hutcheon, “The Louisville Riots of August, 1855," The Register of the Kentucky Historical Society 69, no. 2 (1971): 151.

${ }^{8}$ Charles Deusner, "The Know-Nothing Riots in Louisville," The Register of the Kentucky Historical Society 61, no. 2 (1963): 124.
} 
sympathizers instead used these statistics as "examples" of an inferior immigrant behavior and mental capacity. ${ }^{9}$

According to James Klotter and Craig Friend, the incredible numbers of immigrants settling in Kentucky's most populated cities were also viewed as threats to "job security and cultural integrity." ${ }^{10}$ Anglo-Americans immediately considered these groups opponents on the labor market, as well as challengers to the dominant Protestant orientation of the city, whether for their Catholicism or the radicals' aversion to religion altogether. As these groups strengthened in influence and congregation, the popularity of the Know-Nothing party increased, with Louisville the epicenter of the nativist party in Kentucky. Already by 1841, the abundance of Catholics in the city caused the bishop to relocate there from nearby Bardstown. A decade later, the Cathedral of the Assumption (shown in Figure 13 below) had opened its doors to thousands of more Catholics. ${ }^{11}$ The structure towered over all other buildings nearby, visual proof that Catholicism was at that point thriving in the River City, thanks in large part to its immigrant congregants. Though not nearly as politically active as German radicals and their supporters, Catholics actively defended their rights. In 1853, Bishop Martin John Spalding questioned whether Catholics should pay taxes to support Louisville's public schools, since no one paid taxes to support private Catholic schools. ${ }^{12}$ The predominant nativist county school board would address his concerns by eventually purging all instructors of Catholic faith from the public school system.

\footnotetext{
${ }^{9}$ Deusner, "The Know-Nothing Riots," 124.

10 James C. Klotter and Craig Thompson Friend, A New History of Kentucky (Lexington: University of Kentucky Press, 2018): 163.

${ }^{11}$ Leslie Harper, "Lethal Language: The Rhetoric of George Prentice and Louisville's Bloody Monday," Ohio Valley History 11, no. 3 (2011): 29.

12 Harper, "Lethal Language," 29.
} 
Local Irish and German immigrants were not only targeted for their Catholicism. Walter N. Haldeman, then editor of the Louisville Daily Courier, criticized Germans for their aversion to worshipping in the accepted Protestant manner of the time, in which Sunday was considered a day for rest and spiritual reflection. A couple of months before the election riots of 1855 , Haldeman wrote that Germans "make each Sunday a Saturnalia and with all their might are attempting to Europeanize our population." ${ }^{13} \mathrm{He}$ added that "in our vicinity there are three gardens over-run with visitors each Sabbath," and their apparent disregard for religious rules through social activities would only "increase with every new infusion of the foreign element." With these lines, Haldeman implored native readers to take these cultural differences seriously, as they were a threat to respectable society and traditional American values.

The subject of anti-Catholicism and anti-foreign sentiment in Louisville during this time, however, cannot be accomplished without a thorough account of George Prentice's editorials in the popular Louisville Journal. A prominent Whig, Prentice was left without a platform following the party's dissolution in the beginning of the 1850s. Also a staunch unionist, Prentice became attracted to the beliefs of the Know-Nothing party. Thus, his support went to the KnowNothings, the sole party that could preserve the current state from the "foreign party that desecrates" good American citizens. ${ }^{14}$ Since the Know-Nothing party identified immigrants as the true culprits of national divide, Prentice attacked those groups in his own city, his paper eventually taking on the role as the most notable nativist mouthpiece within Louisville.

Yet Prentice was not alone in his use of virulent and violent rhetoric. As Deusner explains, "editors in that time were more frank and more likely to give expression of their fears

\footnotetext{
${ }^{13}$ Louisville Daily Courier, Tuesday, June 12, 1855, 1.

${ }^{14}$ Louisville Journal, Tuesday, July 12, 1855, 2.
} 
than do present-day newspapermen." 15 Harper states that "editors did not want to present an unbiased summary of the facts; rather, they wanted to sell newspapers and promote their own or their political party's interests." ${ }^{16}$ The nineteenth century was indeed an era of the "personality press," when one of the most popular forms of entertainment derived from newspapers and their entertaining editors, Prentice included. Betty Congleton argues that Prentice utilized personal journalism for the sake of notoriety decades before officially joining the Know-Nothing party. ${ }^{17}$

Over the course of 1855 , Prentice aggressively criticized immigrant religious and political groups as the most destructive groups residing in the city. In his mind, Catholic and secular immigrant forces conspired to destabilize the entire Union. On July 26, 1855, days prior to the election, Prentice claimed that Rome "sends its mandates to willing subjects scattered all over the world.... We must refer to this unity of political action by foreigners in this country."18 The popular editor's opinion that religious groups coalesced with their radical immigrant brethren against the Anglo-American majority was a common view shared by many KnowNothing supporters at the time.

In reality, however, Catholic immigrants and their liberal forty-eighter counterparts hardly claimed a definitive alliance. In the Louisville Platform, for instance, Heinzen feared that Catholic immigrants would bring monarchism and their so-called unhealthy devotion to authority into the United States. Likewise, Catholics criticized Heinzen for using the press as an "organ for promoting American atheism" among immigrants. ${ }^{19}$ They did agree, however, that the rise in nativist sentiment—not Catholicism—proved the largest enemy to their community.

\footnotetext{
${ }^{15}$ Deusner, "The Know-Nothing Riots in Louisville," 135.

${ }^{16}$ Harper, "Lethal Language," 39.

17 Betty Congleton, "George D. Prentice and Bloody Monday: A Reappraisal," The Register of the Kentucky Historical Society 63, no. 3 (1965): 227.

${ }^{18}$ Louisville Journal, Thursday, July 26, 1855, 2.

${ }^{19}$ Der Wahrheits-Freund. Cincinnati, Hamilton City, Ohio: Rev. Mr. J.M. Henni. Jahrgang 18, nr. 25, Thursday 18 Feb. 1855, p. 293.
} 
Furthermore, all immigrants - no matter their religious or political views - held deep protective feelings for those communities and the culture shared among neighbors. Such positions strengthened Prentice's and other nativists' claims that immigrants--as one body--acted as a menace to moral American society.

One of Prentice's first major attacks against Louisville's German community came in 1844, when the Beobachter am Ohio criticized the challenges faced by the foreign-born in their attempts to vote. When rumors insinuated that nativists planned to block their entry, the editors of the Beobachter encouraged Germans to bring weapons along with them on their way to the polls. Prentice promptly reprinted this order in English and manipulated its true meanings in the Journal, causing the editors of the Beobachter to release a public retraction of their statements. ${ }^{20}$ Unfortunately, this story did not simply end with their apology. On that national election day, Whiggish nativists indeed attempted to prevent any immigrant from voting. The mob even congregated in front of the Beobachter editing office, threatening the editor with his life and forcing him into hiding. When their candidate and Kentucky native Henry Clay lost to Democrat James Polk, Louisville residents largely blamed the immigrant population for their accused slavish devotion to the Democratic party. ${ }^{21}$ Such assumptions were aided by Prentice's rhetoric on immigrants who had wrongly influenced an American election and robbed Clay of his rightful position. During this time, a majority of foreign-born voted Democrat as it appeared as the "proimmigrant" party, especially in the mid-1850s when the only other viable alternative was the outspokenly anti-immigrant Know-Nothing party. In reality, a significant number of Germans loathed the Democratic party for its tolerance of slavery. Such sentiment serves as yet another example of the broad characterizations that grouped all foreign-born in the United States.

\footnotetext{
${ }^{20}$ Congleton, "George D. Prentice," 219.

21 Harper, "Lethal Language," 30.
} 
Between 1850 and 1853, as Catholics erected more churches in Louisville and leading German figures like Heinzen and Stierlin helped establish and strengthen local labor unions and community societies, Prentice's attacks against immigrant groups as one unified threat grew obsessive. His focus on the city's immigrant community is reflected in the increase in prejudiced attacks on Irish and Germans throughout 1853 and until Bloody Monday. ${ }^{22}$ On April 24th, 1853, a group of "country Rowdies" assaulted a meeting of German Turners for wearing traditional attire by beating them with short clubs. ${ }^{23}$

On October 8th, 1853, George Prentice published an article claiming that "about five hundred of our Germans entertain infidel sentiments, and rank themselves as members of the Turners' Society, the General Workmen's Association, and Freemen's Association." ${ }^{24} \mathrm{He}$ continued by naming Karl Heinzen as the leader of the Workmen's Association. These groups allegedly indoctrinated their young with the idea that "there is no God but nature." ${ }^{25} \mathrm{He}$ went into additional detail about the beliefs of the Turnverein, describing the group as "socialistic, aiming at the establishment of a Social Republic of Germany and the United States."26 Prentice's misrepresentation of the Turnverein did not end with this claim. In February of 1855, the editor denounced the group for celebrating Thomas Paine's birthday, a loathsome figure who Prentice condemned as an alcoholic, philanderer, and — most importantly — a loathsome atheist. Citing Voltaire, Prentice remarked that "“what must be the religion where a monkey is the priest?"”27 Turning serious, the editor proclaimed that "the perpetuity of our republicanism would be

\footnotetext{
22 Ibid, 31.

${ }^{23}$ William O'Toole and Charles E. Aebersold, "Research Note: Louisville's Bloody Monday Riots from a German Perspective," Filson Club History Quarterly 70 (October 1996): 420.

${ }^{24}$ Louisville Journal, Saturday, October 8, 1853, 2.

${ }^{25}$ Ibid.

${ }^{26}$ Ibid.

${ }^{27}$ Louisville Journal, Friday, February 2, 1855, 2. Emphasis mine.
} 
safe...as long as the vitalities of Christianity were the life-blood of this government." 28 A few weeks later, Prentice quipped that the group said they “practice 'virtue and gymnastics.' Innocent lambs! But what had their 'virtue and gymnastics' to do with their open celebration of Tom Paine's birthday?"29

Prentice continued with his denouncement of these immigrant groups, connecting their beliefs to "red republican" Karl Heinzen, "author of the manifesto of a gang of democrats, who had been hurried over the frontiers of Germany." ${ }^{30}$ Prentice demonstrated fearsome rhetoric in his description of Heinzen's beliefs, explaining that "he calls for blood - a sea of blood.... He advises to undermine cities containing 100,000 inhabitants, and to blow them up with powder."31 In his view, these conspiratorial groups "proclaimed the necessity of a German party in 1854" in order to upend "the foundations of the American Government." 32 Prentice also associated the editors of the Anzeiger with Heinzen's ideology, claiming that "these are the pleasant things to which the Anzeiger is inviting the people of Kentucky." 33 According to Prentice, German immigrants had brought these radical groups over from Europe after "the waves of European horror threw [these] atheistic anarchists...upon our land."34 This comment demonstrates that German radicals were not the only figures who noticed and emphasized the legacy and impact of the Revolutions of 1848-49 in the United States. Know-Nothings referenced them, too, only in a menacing tone for how such ideals could undermine their definitions of American republicanism.

\footnotetext{
${ }^{28}$ Ibid. Compare to Dana W. Logan, "Republicanism: Religious Studies and Church History meet Political History," Church History. Sept. 2015, 84/3, 621-624.

${ }^{29}$ Louisville Journal, Thursday, February 22, 1855, 2.

${ }^{30}$ Louisville Journal, Saturday, February 10, 1855, 2.

${ }^{31}$ Ibid.

${ }^{32}$ Ibid.

${ }^{33}$ Ibid.

${ }^{34}$ Louisville Journal, Wednesday, February 14, 1855, 2.
} 
The Anzeiger responded to such accusations by defending their affiliations with workingmen's groups and other radical associations, proudly proclaiming to an incensed Prentice that "we here declare that we in many points agree with the person and societies above referenced to." ${ }^{35}$ The German editors stood firmly by their own definitions of true republicanism, expressing their belief that such a philosophy had been borne and "existed centuries before this Republic was founded" in the German lands when Frederick the Great allowed "'each man to become blessed in his own way," a freedom of and from religion that they believed hardly existed in the United States at this time. ${ }^{36}$

The Anzeiger and its allied groups publicized these bold statements in an increasingly hostile local environment. In 1854, a city council dominated by Know-Nothing members declared that all extracurricular club meetings begin and end before ten o'clock each night. ${ }^{37} \mathrm{~A}$ harmless measure at first, this local law targeted labor unions and social clubs, as many workingclass men and women did not leave work until the evening, and therefore only had the night to come together. The number of radical organizations like the Bund Freier Männer and Bund Freier Frauen, antagonized Anglo-Americans with their demands for workers' and women's rights. As a local chronicler, Stierlin noted at the time that rather than making progress in terms of new rights for foreign-born, Heinzen's "famous" Louisville Platform "[accelerated] the outbursts of Knownothingism." ${ }^{38}$ In November of 1854, a substantial Know-Nothing rally took place within the streets of Louisville, numbering up to 10,000 people, intent to intimidate nearby immigrant communities with their massive numbers. ${ }^{39}$

${ }^{35}$ Louisville Journal, Saturday, February 17, 1855, 2.

${ }^{36}$ Ibid.

${ }^{37}$ O'Toole and Aebersold, "Research Note," 421.

${ }^{38}$ Stierlin, Der Staat und die Stadt Louisville, 161-62.

${ }^{39}$ Deusner, "The Know-Nothing Riots in Louisville," 134. 
This event sparked rage and a threat to German and Irish neighborhoods. In response, Germans formed a protective organization called the Sag-Nichts, or Say-Nothings. The group mainly included Germans, but also accepted Irishmen and other anti-Know-Nothing individuals into the "secret" society, as it was described by nativist editors like Prentice. In reality, the SagNichts were more strongly associated with neighborhood watches to defend immigrant communities against Know-Nothing gangs who might infiltrate these areas and assault foreignborn individuals. Nativist gangs proved a real threat to immigrant communities across the country in the mid-nineteenth century. In some areas, they acted as a paramilitary unit, infiltrating foreign-born communities and assaulting inhabitants with little repercussions.

Rather than viewed as a local defense organization against such persecution, the AngloAmerican popular press presented the Sag-Nichts as a dangerous militia further ignited efforts by the nativists to undermine immigrant attempts to strengthen their status in local society. Indeed, according to Prentice, the Sag-Nichts proved the largest threat originating out of foreigndominated neighborhoods. For the entire year of 1855, the Sag-Nichts were almost always brought up in his discussions of immigrant activities in Louisville. In March of 1855, he called attention to their rising numbers throughout the state, as well as their German name. ${ }^{40}$ The next month, overwhelming electoral victories, in which nativist candidate John Barbee was elected mayor of Louisville, stimulated Prentice on a years' long tangent against the Sag-Nichts. ${ }^{41}$ On April 21, the editor began by mocking their name, a bold move for a member of the KnowNothing party. He commented that their "name...implies that they are bounded to be dumb in relation to their principles and their men." ${ }^{2}$ Prentice called the group a unifier of "German and Irish...and, without revealing their faces, their plans, their principles, their measures, or their

\footnotetext{
${ }^{40}$ Louisville Journal, Wednesday, March 28, 1855, 2.

${ }^{41}$ Deusner, "The Know-Nothing Riots in Louisville," 126.

${ }^{42}$ Louisville Journal, Saturday, April 21, 1855, 2.
} 
candidates, seek to control our elections." ${ }^{43}$ Accusing these immigrant groups of threatening the election was a calculated move, as a local election was indeed on the horizon and Prentice hoped the threat of a conspiratorial movement involved in illegal voting would rally supporters of the Know-Nothing party to the polls.

In the lead-up to the May 5 municipal elections, Prentice accelerated his denigrating reports on the Sag-Nichts. On May 1, Prentice explained that "we know not how extensively they pervade the counties," but that at least "two thousand members" resided within Louisville and walked about in squads of ten. ${ }^{44}$ He described that "they have their passwords, signs, and signals, everything...for which they have so ferociously denounced the Know-Nothings." 45 To emphasize the danger that Anglo-American citizens faced by this violent group, Prentice claimed that "no army in the field...was ever more thoroughly drilled than this secret army," one of his more dramatic statements surrounding the election, to be sure. ${ }^{46}$

On election day, rumors spread through the native districts that the Germans, under the protection of the Sag-Nichts, had taken over the polls located in their ward. In reality, fights had erupted out of German frustration toward voter suppression methods. If an immigrant approached the polls to vote, he had to prove his citizenship with papers as well as undergo a lengthy interrogation process ${ }^{47}$ Since those who worked at the polls held nativist views, such questioning could drag on as they prevented any foreign-born from voting. The Know-Nothings thus finished the evening with a sound victory over City Hall, yet electoral statistics revealed sharp divisions between Anglos and immigrants. For the districts in which most Germans resided, votes "went almost three to one against the Know-Nothings, indicating the solidarity of

\footnotetext{
${ }^{43}$ Ibid.

${ }^{44}$ Louisville Journal, Tuesday, May 1, 1855, 2.

${ }^{45}$ Ibid.

${ }^{46}$ Ibid.

${ }^{47}$ Deusner, "The Know-Nothing Riots in Louisville," 136.
} 
the German vote" and their courage to make such strong beliefs known even in the face of open persecution by the city administration and the Anglo popular press. ${ }^{48}$

The German message, clearly received and understood by Know-Nothing sympathizers, sparked more provocation and violence between the two groups. In response to the abuse that some of them had experienced on election day, Prentice argued that "outrages against the foreigners, as bad as they were, were not without provocation." ${ }^{49}$ He went on to dismiss claims that nativists had anything to do with these harassments, explaining that "the American party...is wholly incapable of planning or countenancing violenations of the elective franchise." 50 Prentice further remarked that, across the country, "it is a notorious fact...that foreigners...supply a vast amount of the mob material," so their accusations should therefore have been doubted. ${ }^{51} \mathrm{~A}$ couple of days later, Prentice refocused his attacks against the Sag-Nichts.

On May 19, Prentice emphasized that "there wasn't a drop of American blood" in the Sag-Nichts, and proceeded to raise further alarm about their presence in the city. ${ }^{52}$ "Even here, upon slave soil," such an organization had developed and thrived. ${ }^{53}$ In fact, Prentice claimed that "nine-tenths of the foreign-born population and some hundreds of native-born persons" of Louisville had joined its ranks. ${ }^{54}$ Thus, when Prentice stated that there were no Americans involved with the group, he was most likely implying the Know-Nothing definition of the term, where to be "American" was to espouse certain nationalistic and exclusionist ideals of the correct

\footnotetext{
${ }^{48}$ Ibid, 137.

${ }^{49}$ Louisville Journal, Monday, May 14, 1855, 2.

${ }^{50}$ Ibid.

${ }^{51}$ Ibid.

${ }^{52}$ Louisville Journal, Saturday, May 19, 1855, 2.

${ }^{53}$ Ibid.

${ }^{54}$ Ibid.
} 
or patriotic kind of republicanism. He ended this assertion by stressing that "foreignism," above everything else, "is the predominant element." 55

Attacks toward the German population of Louisville were more than verbal. One night following the elections, the Anglo-American Fire Company "sounded a false alarm," provoking the German Hook and Ladder Company to "respond to the call." 56 When the German squad arrived at what they assumed would be the scene of a fire, they were attacked by the nativist fire squadron, "their wagon demolished" and its pieces "thrown into the river." 57 Throughout the month, numerous elements of German cultural life came under attack by the Know-Nothings of City Hall. The local German militia, "Washington and Sharpshooter Company," was forced to surrender their weapons as a safety concern. ${ }^{58}$ As explained in the previous chapter, the KnowNothing party had associated itself with the temperance movement during this time. Therefore, Lokals were disproportionately targeted by the city council that "refused to renew the licenses of several German saloonkeepers" in the month of May alone. ${ }^{59}$ This angered the German community to the point that Lokal owners immediately filed a grievance, creating a lawsuit against Mayor Barbee and his city council.

There were also accounts of discrimination in the occupational realm. The city council promptly dismissed foreign-born government workers like German-language interpreter Conrad Schroeder. He was replaced with Peter Silar, who could not so much as read or write in German, let alone act as a liaison between the city council and the German community. ${ }^{60}$ In addition to these terminations, the Louisville Board of Education proclaimed that "no school teacher could

\footnotetext{
${ }^{55}$ Ibid.

${ }^{56}$ Deusner, "The Know-Nothing Riots in Louisville," 137.

${ }^{57}$ Rowell, German Cultural Contributions to Louisville, 38.

${ }^{58}$ Ibid.

${ }^{59}$ Ibid.

${ }^{60}$ O'Toole and Aebersold, "Research Note," 421.
} 
be recruited or employed if he was Catholic or foreign-born," therefore any current instructors with such a background were subsequently fired from their positions. ${ }^{61}$

Prentice remained focused on exposing the sinister motivations and affiliations of the city's immigrant population throughout the months of June and July. Furthermore, with the drama of the last election fresh on their minds, Prentice continued to goad immigrant communities. In the early days of July, Prentice announced that the godless Turnverein worked in partnership with the godless Democrat. ${ }^{62}$ On July 9, he announced that Germans were allegedly afraid to attempt to cast their votes for the Democratic party out of fear of nativist retaliation. ${ }^{63} \mathrm{~A}$ few days later, the editor stated that there existed "feelings of bitter hostility...in the minds of the foreign-born against the native-born population." ${ }^{64} \mathrm{He}$ continued, explaining that "the hate entertained by the foreigners toward the Americans knows no bounds," desiring to instill in the minds of his readers that these groups posed a real and dangerous threat to their community ${ }^{65}$ Prentice again commented on the enemy's alleged illegal intent a few days later, stating that Sag-Nichts "place a captain over every five Anti-Americans, and he is responsible for six votes, including his own," implying the group was involved in buying votes. ${ }^{66}$

Significantly, Prentice's next move was to publish Heinzen's Louisville Platform in his newspaper, describing it as "nothing less than an attempt to introduce German Illuminism into democratic America." ${ }^{97} \mathrm{He}$ accused the conspiratorial Sag-Nichts of supporting the document that was "leagued with...abolitionists, jacobins, radicals and enemies of religion and the rights of

\footnotetext{
${ }^{61}$ Ibid.

${ }^{62}$ Louisville Journal, Monday, July 2, 1855, 3.

${ }^{63}$ Louisville Journal, Monday, July 9, 1855, 2.

${ }^{64}$ Louisville Journal, Thursday, July 12, 1855, 2.

${ }^{65}$ Ibid.

${ }^{66}$ Louisville Journal, Tuesday, July 17, 1855, 2.

${ }^{67}$ Louisville Journal, Saturday, July 21, 1855, 2.
} 
property." 68 It was indeed proof that "the American party is right...when it proposes to deny to the foreign hordes...their votes." 69 Prentice used the document that sought to empower immigrants and reform American policies to demonize the German community. As the Louisville Platform had been composed a little over a year prior to its publication in the Louisville Journal, one can conclude that Prentice presented it to remind his Know-Nothing or nativist readers of the beliefs within the German community threatened the peace of their own mid-sized city, and to keep such threats in mind when deciding whether or not it was worth it to head to the polls in the next couple of weeks.

Four days later, Prentice again emphasized the Louisville Platform, claiming that its doctrine represented "the mass of the German population" who desired to "introduce the infidelity and lawlessness of German Illuminism in their place."70 He also pronounced "European immigrants to this country are as a general rule abolitionists." 71 With these provocations in mind, Prentice then challenged his audience, asking "shall they have occasion to burden the innocent atmosphere with their 'Free German' noise on the first Monday in August?"72 Such a question was designed to compel Know-Nothing supporters to arrive at the polls in larger numbers.

The next day, Prentice provided reasons for refusing immigrants their citizenship for several years after their settlement in the United States. In part, he sought to denounce the beliefs and behaviors of those who made up the ranks of the Sag-Nichts and its allied organizations. He maintained that "the insidious efforts of foreigners to wield political power in this country is

\footnotetext{
${ }^{68}$ Ibid.

${ }^{69}$ Ibid.

${ }^{70}$ Louisville Journal, Wednesday, July 25, 1855, 2.

${ }^{71}$ Ibid.

${ }^{72}$ Ibid.
} 
what we have to fear and what we ought jealously to watch." 73 Immigrants, he argued, should forget the beliefs of their old life in another country, and that would thus take years to do so. In the meantime, Prentice believed, their political ideologies and affiliations should not have any opportunity to be expressed through the ballot box. These groups, he cautioned his readers, were dangerous opponents who "will leave no effort unattempted, no trick untried," he explained, hoping to rile them up with the idea that immigrants would attempt to illegally vote and thus tamper with the outcome of the election. ${ }^{74}$ These were, he explained, Roman Catholics as well as atheists and infidels, who were all participators in the same conspiracy.

In response to this fear-mongering, the Anzeiger finally took Prentice to task on his abrasive language and spread of alarming falsehoods. The German editors reasoned with their community that they should have no fear of going to the polls despite Prentice's best efforts to target them as enemy subjects, and that it was their duty as free citizens to fill out their ballots. To fully contradict Prentice's duplicitous representation of immigrants to the people of Louisville, the Anzeiger advised Germans to carry themselves with dignity to perform what they had a right to take part in, and "not to be intimidated by notions of dangers at the polls." 75 The newspaper also instructed to "go early in the morning to cast your vote, before the brandy works its influence, and your rights will be granted you." 76 The reference to brandy —a drink hardly enjoyed by Germans or Irish — suggests that the Anzieger wished for its readers to go to the polls before Know-Nothing gangs became drunk and violent.

The Anzeiger also addressed Prentice as a purveyor of local bigotry. The editor, they claimed, revealed his ignorance of the potential dangers that could arise by heightening

\footnotetext{
${ }^{73}$ Louisville Journal, Thursday, July 26, 1855, 2.

${ }^{74}$ Louisville Journal, Tuesday, July 31, 1855, 2.

${ }^{75}$ Baldwin, "George D. Prentice," 485. Originally published in the Louisville Anzeiger, August 1, 1855.

${ }^{76}$ Ibid.
} 
illegitimate alarm and hysteria among the city's residents. ${ }^{77}$ The paper warned that "as soon as...nationalistic simplemindedness asserts [itself] and the majority of the people tolerate such nonsense, then such a people is no longer to be called a free people," and, therefore, "the more it brags about its freedom and intelligence, the more ridiculous it looks to the world." ${ }^{.78}$ As election day approached, even Know-Nothing Mayor Barbee feared the possibilities of violence between nativist rowdies and foreign-born groups. On August 3rd, Barbee released a statement that "I have selected the following named citizens in the First, Second, and Eighth Wards," all of which were heavily populated by immigrants, "to act as special police in their respective wards during the election Monday next," and proceeded to name around fifty men for the job. ${ }^{79}$ The Anzeiger conveyed its gratitude to the mayor for this move. Even though he had previously been elected on a nativist ticket, the editors reasoned that "for this conduct he has earned the thanks of every well-meaning citizen." 80 Though they may have disagreed with the mainstream Anglo population, the mayor's gesture reflected the efforts of the Anzeiger editors to affirm their right to participate and engage in local politics.

Furthermore, the Anzeiger pressed for peaceful behavior in the upcoming election on August 4th. They advised their readers that "we do not expect anyone to scuffle with rowdies at the polls and to expose themselves to injury, perhaps even death." ${ }^{11}$ In a display of their commitment to democracy and exercise their right to vote, however, they advocated that, even in the face of extreme danger, "it is every citizen's duty to go to the polls," and that every German should cast their vote by whatever means necessary ${ }^{82}$ That Saturday night, a procession took

\footnotetext{
${ }^{77}$ Ibid, 487.

${ }^{78} \mathrm{Ibid}, 486$. Originally published in the Louisville Anzeiger, August 2, 1855.

${ }^{79}$ Louisville Daily Courier, Thursday, August 2, 1855, 8.

${ }^{80}$ Baldwin, "The Public Image of Germans," 487. Originally published in the Louisville Anzeiger, August 4, 1855.

81 Ibid, 488.

82 Ibid.
} 
place, with 1,500 Know-Nothing sympathizers in attendance. The event aimed to intimidate the foreign-born population into steering clear of the polls the following Monday. Yet immigrants "were prepared to take their citizenship duties seriously," as many had indeed fought for and supported such rights in the German Confederation. ${ }^{83}$

On Sunday, the day before the election, the Anzeiger released its last statement, for the newspaper did not publish on Mondays. The editors again urged fellow Germans to the polls. They first advised the community to approach the voting areas individually and not in groups, for it could feed nativist paranoia of a foreign plot. The newspaper wrote directly that "sober and unafraid to the polls - that is the motto tomorrow." 84 The editors beseeched readers to go with confidence and do their duties as citizens - a title for which many of them had sacrificed much back in the German Confederation. "It is freedom which we sought so eagerly to strive for in our homeland," though had failed to realize it in $1848 .{ }^{85}$ These immigrants had not left their "native hearth" for nothing; they did so to "enjoy and practice the rights of free man" to gain opportunities that they could not realize under a monarchical government. ${ }^{86}$ They thus related their right to vote in the United States with their reform campaign of 1848 and 1849 . Though it made references to the former revolutionary struggle, the newspaper reminded German readers to conduct themselves peacefully the next day, to make no aggressions that might provoke the ire of the Know-Nothing gangs.

On the eve of the election, Prentice reminded his nativist readers that the immigrants attempting to vote had not yet "become in heart and life genuine Americans," and thus they should not "be admitted to all the powers and privileges of American citizens for the sake of a

\footnotetext{
${ }^{83}$ Hutcheon, "The Louisville Riots," 157.

${ }^{84}$ Baldwin, "The Public Image of Germans," 493. Originally published in the Louisville Anzeiger, August 5, 1855.

${ }^{85} \mathrm{Ibid}, 491$.

${ }^{86} \mathrm{Ibid}, 492$.
} 
hope that they may improve hereafter." ${ }^{" 77}$ His words on August 6, however, carry the most weight for the violence on that day. Prentice instructed that Germans "should of their own free accord stand back until the native-born freeman shall have recorded their suffrages. ${ }^{" 88} \mathrm{He}$ also commended Mayor Barbee for doing "everything in his power to preserve the peace." 89 Most importantly, however, Prentice issued the most infamous passage related to the events of Bloody Monday. First, he reminded his readership of the possibility that, should the Know-Nothing party fail that day, "the country [will be] given up to foreigners and those who owe allegiance to foreign despots. ${ }^{90}$ These immigrants were abolitionists and Roman Catholics and radicals who sought to "“crush out republicanism,' to break the sacred bonds of our Union and to destroy the freedom of the people!" He then exclaimed in his paper, "Americans, are you all ready? We think we hear you shout, 'Ready.' Well, fire! And may heaven have mercy on the foe."'91 These controversial words would loom over Prentice's reputation for years following August 6th, serving as evidence of his reckless conduct and words by spreading rumors and urging an outbreak of violence against the foreign-born population of Louisville.

Furthermore, though the city's most popular newspaper for German speakers advocated peace at the polls, the editors of the Anzeiger underestimated the animosity on the part of nativists toward their community, and that of other immigrant populations, as well. Despite these calls for passivity, the Anzeiger remained true to its revolutionary roots. This newspaper, first published in 1849 to keep immigrants updated on news of the uprisings in the German Confederation, reminded their brethren as to why many of them and their progressive leaders had traveled to the United States in the first place. They wished to better their position in life,

\footnotetext{
${ }^{87}$ Louisville Journal, Friday, August 3, 1855, 2.

${ }^{88}$ Louisville Journal, Monday, August 6, 1855, 2.

${ }^{89} \mathrm{Ibid}, 3$.

${ }^{90}$ Ibid.

${ }^{91}$ Ibid.
} 
experience liberties, and protest for further rights in a country that supposedly offered a platform to accomplish such goals, an opportunity that had not existed in the German Confederation. For all of the Anzeiger's warnings of violence, exercising their rights as citizens proved more important than avoiding danger on election day.

\section{"Such Villainy and Cowardly Proceedings": August 6th, 1855}

For months preceding the August 6th election, a majority of Louisville's residentsAnglo-American as well as foreign-born — suspected that the events of the day would not proceed in a peaceful manner. ${ }^{92}$ After all, the past several months had certainly not been free of conflict. Michael Heffernan, a resident of Louisville and witness to Bloody Monday, later reported that "'Sons of Sam,"” or members of the local branch of the Know-Nothing party, had "held meetings in private halls," discussing the election in particular as it edged closer. ${ }^{93}$ Within a wider context, according to Leslie Harper, violence on election days in the nineteenth-century United States was not at all uncommon. ${ }^{94}$ Between 1828 and the outbreak of the Civil War, over four hundred riots took place in the South alone, and all were directed toward white minority groups such as immigrants, reported criminals, abolitionists, and insurrectionists. ${ }^{95}$ The Louisville riots of 1855 , however, remain high on the list of the worst anti-immigrant, antiCatholic acts of violence and voter suppression in the country's history.

This particular election, explains Emmet Mittlebeeler, pitted a Democratic candidate against a Know-Nothing contender for a position in Kentucky’s House of Representatives, where the winner would then represent a district made up of four counties, including Jefferson County,

\footnotetext{
92 Baldwin, "The Public Image of Germans," 484-485.

${ }^{93}$ Michael Heffernan, "Bloody Monday in Louisville," in Michael Heffernan Memoirs (Louisville: Filson Club Historical Society, post-1876): n.p.

94 Harper, “Lethal Language," 26.

95 Ibid.
} 
in which Louisville is located. ${ }^{96}$ The year 1855 was a significant one for Know-Nothing candidates in Kentucky, who in the weeks after Bloody Monday, went on to elect Charles Morehead, their first and only Know-Nothing governor. In 1853, the state had elected KnowNothing Senator John Thompson and in 1855 sent another member of the party, John Crittenden, to serve in the U.S. Senate. In the same year, all six of Kentucky's Representatives in the U.S. House were Know-Nothings. Based on this string of recent victories alone, it is perplexing that local nativists in Louisville worried at all about immigrants sabotaging their chances of winning yet another position in the state legislature. Yet anti-immigrant and anti-Catholic rhetoric and actions that had expanded over the past couple of years, paired with a series of electoral successes for the Know-Nothing party in Kentucky, "spawned an atmosphere of hate in Louisville." 97

The riots that took place on August 6th, describes Hutcheon, were carried out in two areas, the dominantly German district and, later on, the section of town in which a majority of the Irish resided.${ }^{98}$ Before dawn, members of Know-Nothing gangs had already crowded around the polling stations, daring any foreign-borns or anti-nativists to attempt to vote. ${ }^{99}$ Anyone who approached the polls with their "yellow American ballot" or badge was permitted to cast their vote, as such a display revealed one's sympathies with the Know-Nothing party. In contrast, "every German and Irishman," Rowell explains, "was driven back by stone's throws and bowie knives." 100 James Speed, then a worker at the courthouse near the polls, provided crucial eyewitness testimony to assaults on the foreign-born who attempted to vote. He reportedly "saw

\footnotetext{
${ }^{96}$ Emmet Mittlebeeler, “The Aftermath of Louisville's Bloody Monday Election Riot of 1855.” The Filson Club History Quarterly 66, no. 2 (April 1992): 197.

${ }^{97}$ Hutcheon, "The Louisville Riots," 157.

${ }^{98}$ Ibid, 158.

${ }^{99}$ Philip Kennedy, “The Know-Nothing Movement in Kentucky: Role of M.J. Spalding, Catholic Bishop of Louisville." Filson Club History Quarterly 38 (1964): 22.

100 Rowell, German Cultural Contributions to Louisville, 39.
} 
from the window Irishmen and Germans beaten and chased from the courthouse yard." 101 In addition, he reported that Know-Nothing supporters, adorned with their "yellow tickets" pinned to their hats or shirts, shouted "Huzzah for Sam" as dozens of others joined in the crowd with "muskets...[and] clubs" at their disposal. ${ }^{102}$ By midday, less than a tenth of the residents of the heavily-immigrant First Ward had successfully cast their ballot. ${ }^{103}$

The strategy put forth by the editors of the Anzeiger clearly had not worked for the Germans and Irish. Rumors spread that two Germans had already been beaten to near death before noon for their attempts to approach the polls. ${ }^{104}$ Keeping the peace evidently was no longer viable if immigrants insisted on asserting their right to vote. Other obstacles faced those trying to cast their vote. Deusner writes that "the Know-Nothing city council did nothing to facilitate voting" in districts heavily populated by immigrants. ${ }^{105}$ Indeed, only one polling station had been issued to service an entire community of foreign-born. ${ }^{106}$

Thus, when only a fraction of immigrants had been able to vote and it was announced that polls were closing, the violence truly began. The first major clash erupted when a group of Germans fired shots into a Know-Nothing election carriage, allegedly from the Armbruster Brewery, killing two people inside. ${ }^{107}$ Other instances of retaliation between Germans and the Irish and their Know-Nothing repressors promptly took place, culminating in massive street

\footnotetext{
101 James Speed, "September 8, 1855," in The Speed Family Papers, 1813-1981 (Louisville: Filson Club Historical Society): 2.

102 Speed, "September 8, 1855," 4.

103 Mallalieu, "George D. Prentice," 49.

104 Rowell, German Cultural Contributions to Louisville, 39.

${ }^{105}$ Deusner, "The Know-Nothing Riots in Louisville," 141.

${ }^{106}$ Ibid.

107 David Grimsted, American Mobbing, 1828-1861: Toward Civil War (New York: Oxford University Press, 1998): 234.
} 
violence. On his way to lunch, courthouse worker Speed advised all immigrants that he came across "not to go near the courthouse" and thus to abandon any attempts at voting. ${ }^{108}$

In the meantime, the authorities ordered by Mayor Barbee to protect the city from such destruction failed in their responsibilities. Even Democrats had mixed feelings about this motion when the mayor had given the command to include more security for the elections, as they suspected the "real intention" of these "peacemakers" would indeed be "just the opposite."109 This impression was well-founded, and eventually proven correct. The appointment of police officers in Louisville at that time was largely dependent on political affiliation. A city marshall, head of police forces in the city, held a position in which not even the mayor could replace. The mayor, however, had the authority to conscript any male resident to a militia. This resulted in security forces that often "were not professional and clearly...subject to political pressures." 110 In the course of the election day, members of the militia "accompanied the bullies" and took part in violence against the foreign-born. ${ }^{111}$

With an absence of security forces to lessen threats of bloodshed and destruction, violence more or less commenced and carried on throughout the night unabated by—and sometimes with the tacit and active compliance of — city authorities (shown below in a later depiction of the day's events in Figure 14). Speed described afterwards that "it was not fighting man to man, but as many as could...fall upon a single Irish or German and beat him." 112 Attempts at mediation came from Mayor Barbee on two occasions. Once violence had broken out, the mayor appealed to his Know-Nothing voters, assuring them of their victory. ${ }^{113}$ By this time, the

\footnotetext{
108 Speed, "September 8, 1855," 3.

${ }^{109}$ Kennedy, "The Know-Nothing Movement in Kentucky," 22.

${ }^{110}$ Mittlerbeeler, "The Aftermath of Louisville's Bloody Monday," 210-211.

${ }^{111}$ Mallalieu, "George D. Prentice," 49.

112 Speed, "September 8, 1855," 3.

${ }^{113}$ Deusner, "The Know-Nothing Riots in Louisville," 143.
} 
assailants had largely forgotten about the election. These uncontrollable gangs instead concentrated on exerting their long-time frustration toward the local immigrant communities, especially their politicized actions of the past few years, and the unavoidable presence of Catholics in the city. Indeed, a large mob promptly turned their attention to St. Martin Cathedral and the Cathedral of the Assumption whose congregants mostly consisted of German and Irish immigrants.

Know-Nothing gangs claimed that weapons had been stored in these places of worship in preparation for an attack on the city's Anglo-American residents and government officials. They threatened to set fire to both structures if a thorough search was not conducted of both churches. A group of mostly German fighters defended their beloved cathedrals against the mob. ${ }^{114}$ The situation was not quelled, however, until Bishop Spalding appealed to Mayor Barbee to call for a search to spare the church's destruction, resulting in the local leader's most important intervention of the day. Following an examination of the grounds of each cathedral, the mayor quickly released a statement later reported by the Wheeling Daily Intelligencer, assuring that "we...have in person carefully examined the Cathedral and do assure the community that there are neither men nor arms concealed there." 115 Mayor Barbee also assured the mobs that the Bishop had handed over the churches' keys to city authorities. Despite this mediation, KnowNothing mobs seemed determined to find the location where immigrants had hidden their weapons. Armbruster Brewery, from which a group of Germans had allegedly fired on supporters of the Know-Nothing party, became a primary target. The nativist horde set fire to the

\footnotetext{
${ }^{114}$ Kennedy, "The Know-Nothing Movement in Kentucky," 22.

${ }^{115}$ Wheeling Daily Intelligencer, Friday, August 10, 1855, 2.
} 
property, causing $\$ 25,000$ worth of damage, though not before indulging and intoxicating themselves with the beer stored inside. ${ }^{116}$

Know-Nothing mobs subsequently redirected their attention to immigrant homes, businesses, and places of cultural importance. To worsen matters, they somehow acquired a cannon to aid in the destruction of the city's immigrant neighborhoods. In addition to a cannon, the mobs utilized "muskets and bayonets" during the course of the night. ${ }^{117}$ They demolished Christian Meier's boarding house that provided lodging to mostly German laborers. Many people who fled the building were shot in their escape. Mobs also attacked the home of Konrad Kissler, who was "smoking a pipe quietly at a Bierhaus" when he heard of the destruction of his residence. ${ }^{118}$

Klotter, a grocer that serviced the German community, received a savage beating as his business was set aflame. Another grocery was also targeted; a new employee, who had just arrived from the German lands a mere three weeks before, was killed as the mob pillaged the store before setting the structure on fire. ${ }^{119}$ Countless other groceries, saloons, and bakeries were burned to the ground, including that of Carl Berthold, who has been referenced in previous chapters. Not surprisingly, every building demolished resulted in several men, women, and children wounded or killed as assailants plundered the stores and homes of their hated adversaries. In addition to these acts of violence, Karl Becker's bakery was destroyed, Karl Heybach's home burned to the ground, and the employees of Daniel Schmuck's confectionary business asphyxiated by the flames and smoke in the building. ${ }^{120}$ As mentioned before, escaping the fire within did not guarantee safety; a spray of bullets, clubs, and other weapons greeted

\footnotetext{
116 Kennedy, "The Know-Nothing Movement in Kentucky," 23.

117 Rowell, German Cultural Contributions to Louisville, 40.

118 Ibid, 39.

119 Ibid.

120 Ibid, 40.
} 
those who fled their shelter. Of course, immigrants found walking along the street were harassed, and sustained severe injuries, leading to death in some instances. Michael Heffernan spoke of an elderly German man assaulted by the mob "when returning from the mail boat," and later died as a result. ${ }^{121}$ Immigrants found by the authorities were placed under arrest, the reasons for which could have been to isolate them from the mobs or because the police considered the foreign-born just as guilty for the outbreak of violence. Indeed, courthouse worker James Speed reported that he "saw many Irishmen" as well as Germans "carried to jail all covered in blood."122

Toward the end of the night, mobs congregated to the city's Irish section, though the district also contained German residents. Irish and Germans - mostly working-class-lived on a street of apartments widely known as Quinn's Row, owned by Irishman Patrick Quinn. The mob fired their cannon toward the apartment complex, believing that Quinn's Row safeguarded the rumored weapons initially believed to have been stored in the cathedrals. Reports had emerged that residents of the apartments had been "molding bullets" for an assault on nativists. ${ }^{123}$ Quinn himself was attacked and killed. Walter Lewis Allawyn, witness to such horrific events and speaking on them later in life, described that Quinn was "hung by the neck on the lamp post, until he was dead." ${ }^{124}$ German and Irish fire companies had their materials and resources destroyed so they were not able to help their fellow neighbors in any substantial way. ${ }^{125}$

The incident on Quinn's Row (an artist's depiction of which is shown in Figure 15) caused the most deaths on Bloody Monday alone, as the entire structure collapsed and took dozens of tenants with it. Anywhere from twenty to one hundred people lost their lives throughout the day and night. The mortality rate remains so uncertain due to the chaos, lack of

\footnotetext{
${ }^{121}$ Heffernan, "Bloody Monday in Louisville," n.p.

${ }^{122}$ Speed, "September 8, 1855," 5.

${ }^{123}$ Deusner, "The Know-Nothing Riots in Louisville," 145.

124 Walter Lewis Allawyn, Additional Papers, 1891-1941 (Louisville: Filson Club Historical Society): 4-5.

${ }^{125}$ Deusner, "The Know-Nothing Riots in Louisville," 145.
} 
authorities present, bodies burned in the flames, an inept investigation, immediate departure of those left homeless, and attempts by the local government to conceal the extent of the deaths and damages from the national press. Nevertheless, the Know-Nothings won yet another position in Kentucky's government. Josiah Stoddard Johnson, who experienced the events of August 6th, commented that "they gained a victory...but that victory was purchased at the cost of innocent lives and by the violation of every principle of right."."26 By their actions, Know-Nothings and their supporters affirmed their opinion that immigrants deserved neither enfranchisement, nor citizenship.

\section{The Aftermath: German Immigrants Move Out and Move On}

Almost immediately after the Louisville riots, George Prentice brandished his pen once more, dodging accusations that nativists had been responsible for the violence committed in the immigrant neighborhoods. On August 8, the editor instead placed all blame on the Sag-Nichts and their thuggish supporters, explaining that "when the Sag-Nichts found they were foiled and could not get up a disturbance at the polls, we suppose they resorted to the dreadful expedient of firing on the people passing in the streets." 127 Prentice also remarked that "all the German houses attacked were those from which shots had been fired by the occupants." ${ }^{128}$ In other words, all foreign-born victims of the riots had instigated the violence, and thus deserved their fate.

One day later, Prentice reiterated his stance that the guilty party on that day was indeed the Sag-Nichts, or "those who drew first blood." $129 \mathrm{He}$ at one point dramatically implored readers to believe him, asserting that the Know-Nothing party could "fearlessly stand up before the

\footnotetext{
126 Johnson, Josiah Stoddard Johnson Scrapbook \#3, 15-16.

${ }^{127}$ Louisville Journal, Wednesday, August 8, 1855, 3 .

${ }^{128}$ Ibid.

${ }^{129}$ Louisville Journal, Thursday, August 9, 1855, 2.
} 
community, whose peace had been thus ruthlessly destroyed, and say with conscientious truth, 'Shake not thy gory locks at me! Thou canst not say I did it.'"'130 On August 11, Prentice downplayed the suffering of the day altogether, claiming that reports that many had died in the Quinn's Row fire were "utterly untrue and without foundation" and concluded that, at most, only a few residents of the immigrant neighborhoods at most had perished that day. ${ }^{131}$

In a solemn letter dated the previous day, however, Bishop Spalding wrote to Archbishop Kendrick of Baltimore, stating that "we have just passed through a reign of terror... [with] nearly a hundred of poor Irish and Germans...butchered or burned. The city authorities, all KnowNothings, look calmly on, and they are now endeavoring to lay the blame on the Catholics." ${ }^{132}$ Though Spalding only mentioned Catholic victims, other groups of immigrants, such as the radical members of local working organizations and cultural societies thought to be associated with the Sag-Nichts, were clearly also targeted by Prentice and other Know-Nothing leaders as instigators of the violence.

Several days later, Prentice laid the blame entirely on the German element within the city. He noted that "particularly since the influx of German commenced...a deluge of fanatical Painites has been poured into the United States...whose natural affiliation to all the elements of radicalism in the land bodes evil to the future welfare of our Republic."133 In this way, he indirectly associated the emergence of violence in the city with increased immigration that occurred at the same time. Furthermore, Prentice professed that contempt for spirituality had especially "taken root...among the German population "that reflected their "socialist, red

\footnotetext{
${ }^{130}$ Ibid.

${ }^{131}$ Louisville Journal, Saturday, August 11, 1855, 3.

132 Kennedy, "The Know-Nothing Movement in Kentucky," 23.

${ }^{133}$ Louisville Journal, Friday, August 17, 1855, 2. Emphasis mine.
} 
republican hatred against religion." 134 Such belief systems, Prentice concluded, "have been transplanted here" by radicals such as Heinzen and his companions. These writers published papers that were "communist and radical-infidel," and soon, they would unite to "become an incurable evil" in their "support of one common cause." 135 Suspicions toward local immigrant communities were thus earned and well-founded, based on such individuals located within their ranks. These figures had allied themselves with Roman Catholics, where it was rumored that this united front "had intended to make an assault upon the Americans so soon as night closed in," Prentice described a few days later, coming full circle in his blame of a Catholic and radical immigrant conspiracy within the city. ${ }^{136}$

Despite Prentice's best efforts to exonerate himself from any wrongdoing in relation to Bloody Monday and designate blame to an immigrant plot, major newspapers across the country denounced Know-Nothingism and the barbaric actions of the party's supporters-including Prentice himself. Indeed, a public relations disaster arose from this violent act of voter suppression. A writer at the New York Daily Times declared that the "bitter and lawless animosity" on the part of nativists needed to have been "properly checked" from the very beginning of this string of violence. ${ }^{137}$ Another paragraph in the same newspaper referred to the Louisville riots as "one of the most availing tragedies that has ever attended a popular election...since the organization of our government." ${ }^{138}$ The Boston Liberator specifically attacked the Know-Nothing-affiliated Louisville Times for its incendiary role in the riots, remarking that their question as to who should be held responsible for the bloodshed "would

\footnotetext{
${ }^{134}$ Ibid.

${ }^{135}$ Ibid.

${ }^{136}$ Louisville Journal, Thursday, August 23, 1855, 2.

137 “Our Mobocracy," New York Daily Times (1851-57), August 14, 1855.

138 “The Louisville Riots--the Tragic Side of Know-Nothingism," New York Daily Times (1851-57), August 8, 1855.
} 
have done credit to Pontius Pilate after the crucifixion of Jesus." ${ }^{139}$ German-language newspapers across the country, from the Columbus Westbote and as far as the New Yorker Staatszeitung, also adamantly denounced the attacks. ${ }^{140}$ As in other occasions of persecution that had taken place before, these newspapers urged communities across the country to collect donations to support their brethren in Louisville whose neighborhoods had been destroyed. ${ }^{141}$ The Anzeiger, too, blamed Prentice, calling him "der alte Hetzer," or "the old rabble rouser," for his part in encouraging the riots. ${ }^{142}$ News of this ferocious act of voter suppression even spread to the German Confederation, to which the Augsburger Allgemeine Zeitung warned of persecution against German immigrants in the United States. ${ }^{143}$

At the local level, ordinary citizens explicitly voiced their opinion that Prentice played a major role in the provocation of violence on election day. In a letter to a companion, Louisville resident H. Cox wrote that "you are further aware that Prentice is making a powerful effort to control the public in Kentucky by way of the Journal filled with the vilest slander...and the most loathsome falsehoods in regard to the Louisville riots and the objects of the Know-Nothing party." 144 On August 29, the Louisville Daily Courier, the Louisville Journal's largest rival, confronted Prentice for placing blame on the Catholic and foreign-born communities of Louisville, challenging him that "if these men are as guilty as you charge them, you owe it to your own character to prove them so. If, however, you find that you cannot substantiate your

\footnotetext{
139 "Who is Responsible for the Riots?" Boston Liberator (1831-65) 25, no. 35 (August 31, 1855 ): 1.

${ }^{140}$ Carl Wittke, Refugees of Revolution: The German Forty-Eighters in America (Philadelphia: University of Pennsylvania Press, 1952): 188. Originally published in the Westbote, August 10, 17, 25, 1855; New Yorker Staatszeitung, August 8, 1855.

${ }^{141}$ Wittke, Refugees of Revolution, 188.

142 Dennis Charles Cusick, Gentleman of the Press: The Life and Times of Walter Newman Haldeman (Louisville: University of Louisville Press, 1987): 29.

${ }^{143}$ Wittke, Refugees of Revolution, 188.

144 H. Cox, “October 22, 1855," in The Norvin Green Papers, 1802-1892 (Louisville: Filson Club Historical Society).
} 
charges against them...then in the name of all that is far and honest cease abusing them."145 This newspaper displayed authentic sympathy for the immigrants of Louisville in contrast to Prentice's Louisville Journal.

Members of the immigrant community reacted strongly to such accusations, as well. Christian Lenz, a German immigrant residing in Louisville at the time and mentioned in previous chapters, was most bleak in his description of the city and the status of Germans in a letter back to his family. In his account of Bloody Monday, Lenz defended the actions of the foreign-born, explaining that they were "beaten and pushed around" to the point that they retaliated with their own weapons. ${ }^{146}$ Determined to keep his nephews from following in his footsteps and migrating to the United States, Lenz detailed vividly "how [Know-Nothings] ran through the streets like the screaming seven to see human blood." ${ }^{147}$ Regretting that he had ever witnessed such an atrocity, Lenz claimed that "even if there's nothing besides bread and potatoes and salt" in Germany, "that is still better than meat three times a day in a foreign country." 148 Know-Nothing violence had succeeded in making Lenz feel unwelcome and foreign in his new home.

German-language newspapers, including the Anzeiger, encouraged Germans to leave the area for larger German communities in St. Louis, Milwaukee, and Chicago, to which many complied. ${ }^{149}$ On August 11th, George Phillip Doern of the Anzeiger raised the question if "Louisville may still count itself among the well-mannered and civilized cities of the world; each one should weigh this question and if we have a majority against us, then we give up every claim

\footnotetext{
${ }^{145}$ Louisville Daily Courier, Wednesday, August 29, 1855, 1.

${ }^{146}$ Christian Lenz, "Louisville, October 22, 1855," in News from the Land of Freedom: German Immigrants Write Home. Walter D. Kamphoefner, Wolfgang Helbich, and Ulrike Sommer, eds. (Ithaca: Cornell University Press, 1988):134.

${ }^{147}$ Lenz, “October 22, 1855," 134.

148 Ibid.

${ }^{149}$ Wittke, Refugees of Revolution, 188.
} 
to continue to be a citizen" of the city. ${ }^{150}$ Stierlin reported three days later that "around two hundred persons, mostly Germans, met and formed a society for leaving Louisville, the Amerikanischer Auswanderung Verein." 151 Though this group never managed to organize their trip out west to establish a German colony of their own, many Germans independently departed the city.

Rowell explains that "whoever could do it sold his property and turned his back to the city." "152 They abandoned the destruction of their homes, businesses, and neighborhoods, to begin lives in places with larger and more established German-speaking communities. In a letter back home, Carl Berthold hinted that business had turned poor in Louisville, though unlike Lenz, he did not specify the reasons for the economic downturn. "Business is doing fairly poorly," he wrote, with no indication that his store had been practically demolished, "so tomorrow I am going to the South and I think I'll do better business there." 153 These immigrants - many of which had been active in local politics - were on the move once more. It was not an absolutist monarchy they fled, but a party of intolerant adversaries and street thugs.

In addition to their appeals to leave the city as a matter of safety, the German press across the country dedicated entire pages of their issues to document the anti-German violence, reporting on trials in the wake of these riots to ensure that justice was served. ${ }^{154}$ In Louisville, however, no one received a conviction for their actions on August 6th, though so many arrests were made that day — mostly of foreign-born — that every jail in the city reached its capacity.

\footnotetext{
${ }^{150}$ Baldwin, "The Public Image of Germans," 494. Originally published in the Louisville Anzeiger, August 11, 1855.

${ }^{151}$ Stierlin, Der Staat und die Stadt Louisville, 173.

${ }^{152}$ Rowell, German Cultural Contributions to Louisville, 42.

${ }^{153}$ Carl Berthold, "Louisville, October 25, 1855," in News from the Land of Freedom: German Immigrants Write Home. Walter D. Kamphoefner, Wolfgang Helbich, and Ulrike Sommer, eds. (Ithaca: Cornell University Press, 1988): 331.

${ }^{154}$ Carl Wittke, The German-Language Press in America (Lexington: University of Kentucky Press, 1957): 133.
} 
According to Mittlebeeler, members of Know-Nothing gangs had left the city to avoid prosecution. In addition, the chaos of Bloody Monday and the absence of authorities resulted in a confusing timeline and little clarity in regard to the number of deaths and those responsible. Victims or witnesses who remained in Louisville proved "unwilling to testify" out of fear that they would again be targeted by nativists. ${ }^{155}$ Hesitation to come forward resulted in a record that consisted largely of native-born accounts, and painted a stark picture of the events of August 6, in which the foreign-born were the aggressors.

Prentice aided in this new and lasting portrayal. Indeed, it was part of his best interest to redirect the blame from his newspaper and its political affiliates that he claimed had been "so atrociously vilified." 156 If anything, Prentice claimed, he was only to blame for inciting supporters of the Know-Nothing party to the polls. For this endeavor, he could only report that his "appeals" had been "more powerful, more dignified, and decent" than those editors in support of the Democratic candidate. ${ }^{157}$ Furthermore, accusations toward nativist voters that day had gone to the extreme, Prentice claimed, as he accused "all of the Sag-Nichts papers abroad" for reporting that "Know-Nothings on the 6th...beheaded the foreigners." ${ }^{158}$ Indeed, Prentice as well as the city authorities of Louisville hoped to create a different interpretation of the day's events through testimonies and affidavits, part of which were subsequently published in the Louisville Journal as proof that the foreign-born were the guilty parties, and would thus help to exonerate Prentice and his newspaper.

Shortly after the riots, the Testimony as to the Origins of the Riots in the City of Louisville appeared. This document recorded eyewitness accounts of the violence surrounding the recent

\footnotetext{
${ }^{155}$ Mittlebeeler, "The Aftermath of Louisville's Bloody Monday," 218.

${ }^{156}$ Louisville Journal, Saturday, August 25, 1855, 2.

${ }^{157}$ Ibid.

${ }^{158}$ Louisville Journal, August 31, 1855, 2.
} 
election, drawing from primarily American perspectives with a handful of immigrant accounts. Almost all of the testimony identified the foreign-born as instigators of the riots. Reports on the district in which mostly Irish immigrants lived noted their aggressive acts that day. W.M.

Sowders, an Anglo, described that, early in the day, "Irishmen immediately drew out revolvers and commenced firing upon the crowd." 159 John T. Trice, a worker at a local paper mill, also commented that there had been no violence "up to the time of this shooting by the Irish." 160

At the onset of these attacks, eighteen-year-old Richard Marsh reported that "the crowd of Americans scattered when the firing commenced."161 Ruby Dodd, who resided near Quinn's Row, "observed...for nearly two weeks...armed [Irishmen] passing in and out of the alley, and heard guns and pistols fired during the nights," hinting to a premeditated conspiracy on the part of the Irish immigrant population, as Prentice had stipulated earlier. ${ }^{162}$ In contrast to the accusations that American ruffians attacked those fleeing the flames of Quinn's Row, Dodd added that she "saw a number of Americans assisting the women and children to escape."163 Why the Irish residents would have set their own homes on fire, she did not explain.

Not surprisingly, all American perspectives on the violence in the German quarters of the city cast the blame directly on their immigrant neighbors. Richard H. Lee, a policeman, "made several Dutchmen put up weapons, with which they came to the polls," evidently with the hope of starting a fight. ${ }^{164}$ James Irwin also noted that Germans behaved aggressively in their attempts to vote that day, and one even tried "to draw a pistol on" one of the Americans due to their

\footnotetext{
159 “Testimony as to the Origins of the Riots in the City of Louisville, KY. "Hull \& Brother, Printers, 1855, 4. Also published in a condensed form in the Louisville Journal, August 15, 1855, 2.

160 "Testimony," 5.

161 Ibid.

162 Ibid, 6.

163 Ibid, 7.

164 Ibid.
} 
impatience for having to wait in line. ${ }^{165}$ D.T. Bligh claimed that hardly any Know-Nothing supporters were armed that day, while "the Germans were generally armed with...almost every description of guns."166 Another testimony by W.M Adkins reported that "the Dutch, aided by their women, were preparing their arms" in advance of the election, just as Dodd had accused the Irish of doing. ${ }^{167}$

The Germans, as they were described in these reports, appeared uncontrollable and incapable of reason that day due to their blind hatred for Know-Nothing voters, as well as AngloAmericans in general. Joseph D. Selvage, a sheriff who worked at the polls that day, "begged the Germans not to shoot at the Americans anymore, but they did anyway and the fighting commenced." 168 Indeed, it was the Germans who began the violence in the first place, when they targeted a "one-horse wagon with two or three men quietly passing" with stones and fists, as Alexander C. Cross described. ${ }^{169}$ John Pettit, who lived across from Armbruster's Brewery, claimed that Germans had congregated inside the brewery and "commenced firing their guns from the brewery upon inoffensive citizens passing by." 170 This served to justify Know-Nothing supporters' targeting of the brewery later in the day. It was not an attack, but rather an act of selfdefense.

Immigrant accounts in the testimony concurred with the statements offered by the Anglo reports. Caroline Wall, an Irish Catholic, claimed that her fellow Irish residents had been "preparing for a fight, and procured and had man arms, pistols, and guns." The woman then

\footnotetext{
165 Ibid, 11 .

166 Ibid.

167 Ibid, 13.

168 Ibid, 12 .

$169 \mathrm{Ibid}, 14$.

170 Ibid, 15 .
} 
declared, "they had resolved...to attack the procession." 171 Likewise, John Vogt--a German arrested for taking part in the assault on American voters--claimed that he was "strongly induced by several Americans and several Germans to fire upon the Americans," and subsequently expressed his regret for complying with such orders. ${ }^{172}$ Lawrence Bergmann, another German immigrant, reported that "some fifty Germans presided in front of his house, carrying an effigy of him, and using violent threats toward him" for opposing their radical visions for reforming the country. ${ }^{173}$ Ultimately, these descriptions complemented one another to the point that they substantiated Prentice's claims about an underlying immigrant conspiracy. Indeed, the editor concluded that these reports "are sufficient to show clearly upon whom rests the responsibility of having commenced the outrages," continuing his point, "that the foreign population were the only agitators in these lamentable riots." 174

In light of these affidavits and written accounts, cases against Know-Nothing suspects made it all the way to the Board of Aldermen - the upper chamber of the city's legislative branch — but most were promptly dismissed with the explanation that "mobs rarely if ever occur in this country unless some great outrage has been perpetrated...against the moral sense of the whole community." 175 After all, "the heart of the American people is naturally on the side of right and in favor of the maintenance of law and order." ${ }^{176}$ Though the Board of Aldermen condemned the violence, stating that "neither favor nor encouragement should be given to those whose conduct tends to create mobs," it ultimately cast the blame on the inability on the part of immigrants to assimilate into Anglo-American society. It concluded that it is ultimately the

\footnotetext{
171 Ibid, 7.

172 Ibid, 11.

173 Ibid, 16.

${ }^{174}$ Louisville Journal, August 15, 1855.

${ }^{175}$ Louisville Journal, Saturday, August 25, 1855, 1. Originally transcribed in "Minutes." Board of Aldermen, August 23, 1855.

${ }^{176}$ Louisville Journal, August 25, 1855.
} 
responsibility of the opposing forces in society "as well as their interest...to conciliate than to aggravate." 177 Such verdicts, released in the Louisville Journal a couple of days later, revealed the extent to which the Know-Nothing party had infiltrated state politics.

The Board of Aldermen may have sided with the Know-Nothing party, but the future of the organization quickly diminished as they suffered continual losses nationwide, especially due to the formation of the Republican Party and the outbreak of the Civil War. Nevertheless, the Know-Nothing movement maintained popularity in Louisville. ${ }^{178}$ In June of 1857, Tyler Anbinder points out, Know-Nothing leaders chose to host their final national conference as an organized party in the River City. ${ }^{179}$ They knew this to be their last meeting, thus it was in Louisville that they "abolished their oaths." ${ }^{80}$ Notable state politicians had distanced themselves from the nativist organization since Bloody Monday had garnered national outcry. Abraham Lincoln, writing in August of 1855, castigated the party altogether, explaining that its platform stood contrary to the concept that all men are created equal. If Know-Nothings ever took power, Lincoln proclaimed, "I shall prefer emigrating to some country where they make no pretense of loving liberty - to Russia, for instance, where despotism can be taken pure, and without the base alloy of hypocrisy." "181 Based on the time in which he wrote this letter, it is considered an indirect response to the events of August 6th.

On that election day in Louisville, nativist gangs attacked Germans and Irish residing in the city. They set fire to neighborhoods in which the signs of stores, beer gardens, and pubs were written in German, and churches, labor unions, and singing societies conducted their services in

\footnotetext{
${ }^{177}$ Ibid.

178 Deusner, "The Know-Nothing Riots in Louisville," 147.

179 Tyler Anbinder, Nativism and Slavery: The Northern Know-Nothings and the Politics of the 1850s (New York: Oxford University Press, 1992): 247.

180 Hutcheon, "The Louisville Riots," 170.

181 Abraham Lincoln, Collected Works, v. 2. (New Brunswick: Rutgers University Press, 1953): 23.
} 
the native language of their members. Through such actions, these Know-Nothing members assaulted the entire culture and traditions of a productive immigrant community. These enclaves, however, remained strong and resilient as they upheld their organizations and press, even if some ultimately had to do so in another state.

Know-Nothing supporters like George Prentice characterized local immigrants as instigators of the violence to conceal their own culpability for the day's carnage. In the days leading up to the riots, Prentice emphasized the radicalism and underlying conspiracies in which local immigrants - in his mind — were most certainly involved. His sudden republication of the Louisville Platform weeks before the election, for instance, sought to connect Heinzen's ideas with the local Sag-Nichts group, and thus to indicate that the controversial reforms that he had pursued in Louisville remained alive with the immigrants who resided in the city. The nature of the riots, then, are part of Heinzen's legacy in Louisville, as its republican aggravated preexisting hostility toward the foreign-born and, coupled with Prentice's hateful rhetoric, indicated to many nativists that local immigrant communities endeavored to destroy their interpretation of a Republic.

Afterwards, however, Louisville's German neighborhood steadily rebuilt their homes and businesses, regaining their livelihoods. They exercised cultural pride, emphasizing language retention and upholding their beloved newspapers like the Anzeiger, which largely remained in service to local labor groups and other political and so-called "radical" organizations. From the barricades of 1848 to the banks of the Ohio River in 1855, German immigrants and their fortyeighter brethren and leaders strongly voiced their interpretations of republicanism, declaring their right to participate in politics and engage in democratic practices and institutions. Workers, artisans, and radicals like Heinzen contributed the necessary tools to realize such goals. They 
considered their role in the practice of real democratic government a grand demonstration of loyalty to the theoretical political values of the United States. Turnverein, union members, and their organizers envisioned the United States as the only place where they could potentially achieve those goals so aggressively fought for in the Revolutions of 1848 and 1849. Many discovered, however, that tyranny existed in multiple forms and in their own cities. The beliefs that they had carried with them in their migrations, however, were evident and strengthened when, on a local election day, these Germans exercised their rights to participate in the civic and political realm of their new homeland. 


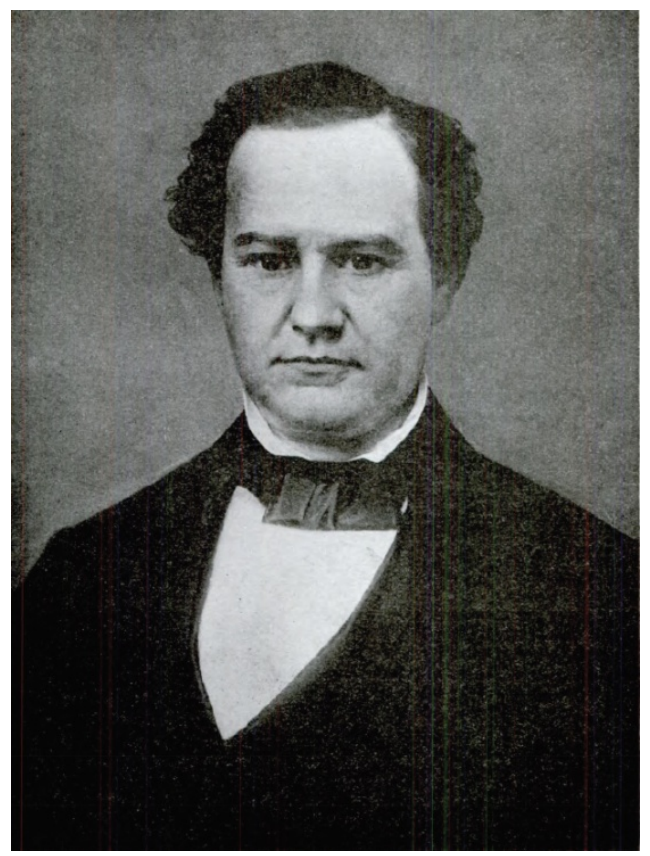

Figure 11: George Prentice. Courtesy Filson Club Historical Society.

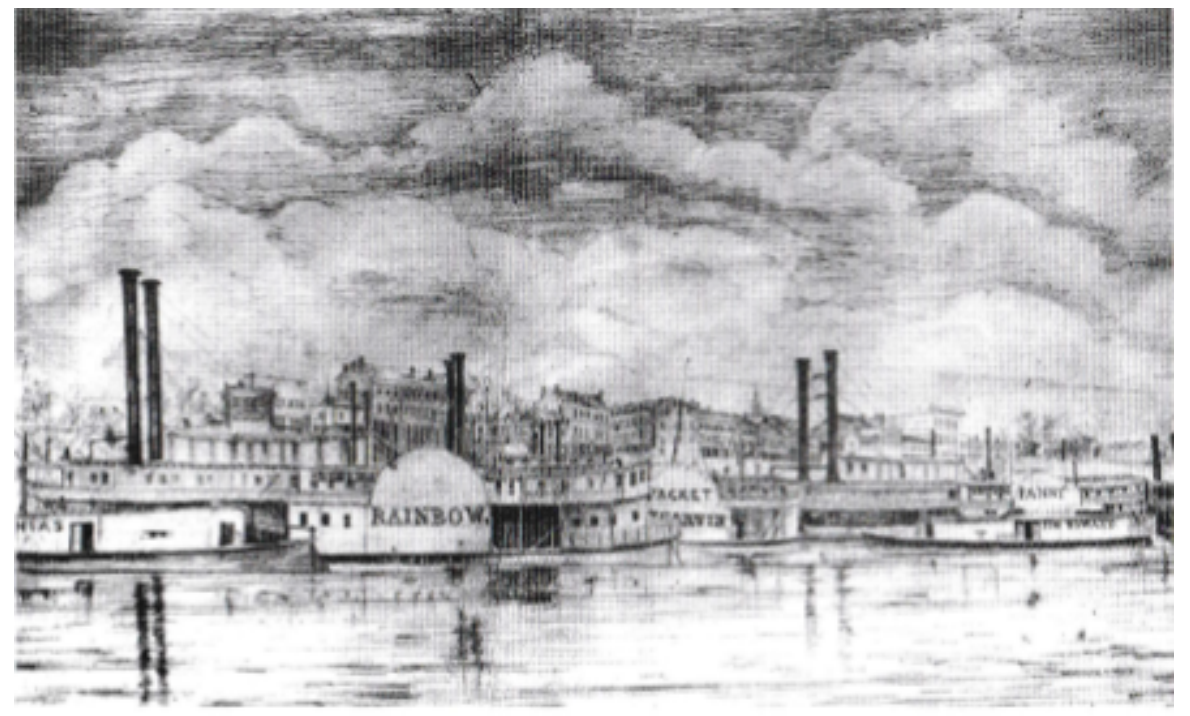

Figure 12: Louisville Wharf District, 1855. Courtesy University of Louisville Photographic Archives. 


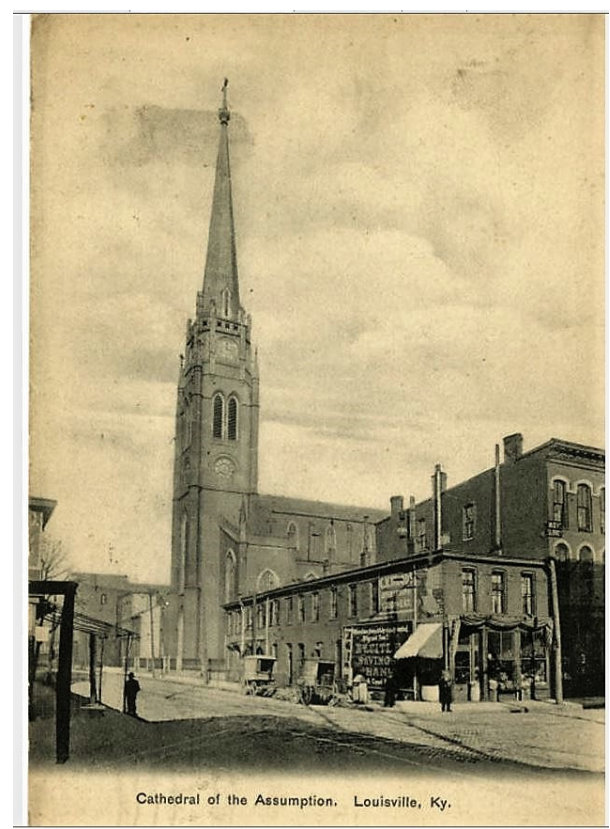

Figure 13: Cathedral of the Assumption. Courtesy Kentucky Historical Society.

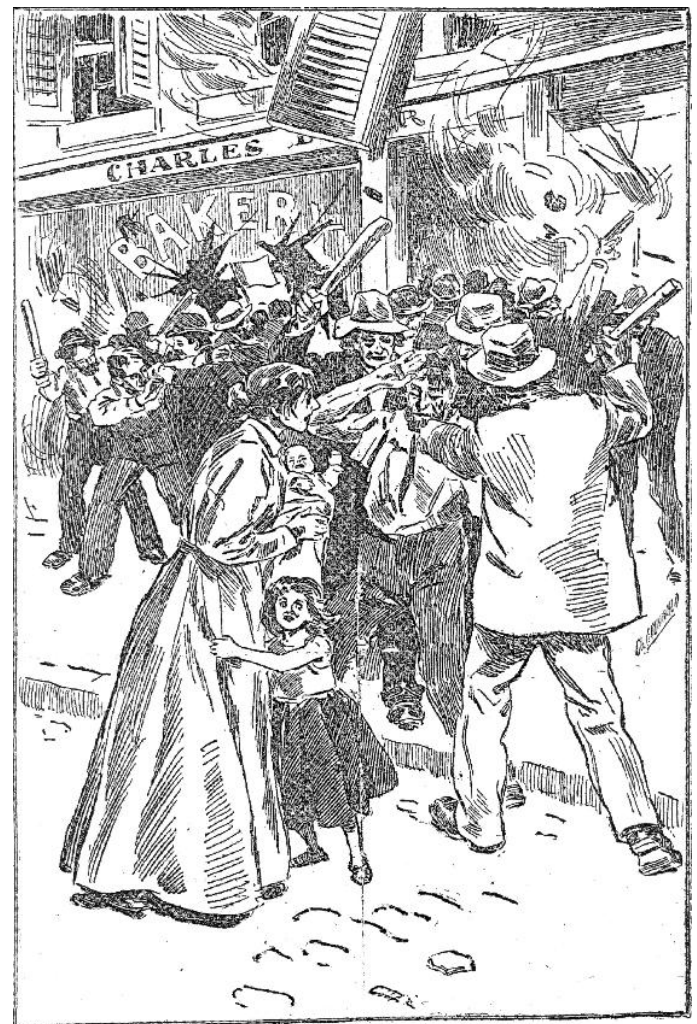

Figure 14: Bloody Monday Riots on Shelby Street near Becker's Bakery. Courier-Journal, November 7, 1897. 


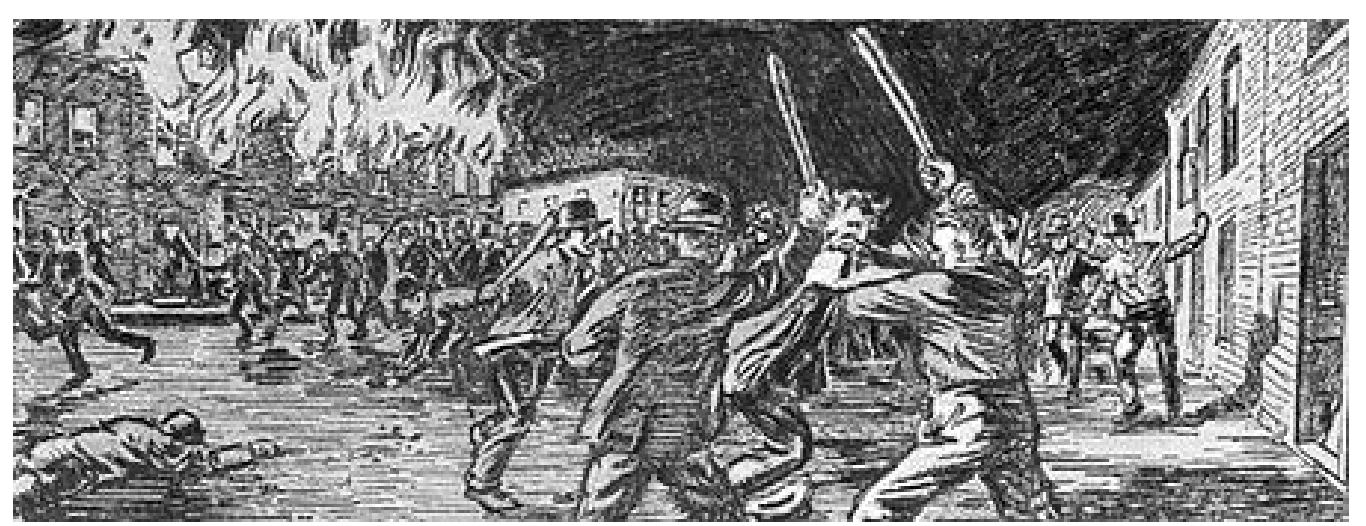

Figure 15: The Burning of Quinn's Row, Louisville Herald, September 5, 1922. 


\section{Conclusion: The Transnational and Transcultural Legacy of the Revolutions of 1848}

This comprehensive work connects nineteenth-century republican ideas about civic political engagement from Baden during the Revolutions of 1848 and 1849 to the thriving German community in the unassuming, medium-sized town of Louisville, Kentucky, in 1855. It has revealed that politicized Germans of the late 1840s and early 1850s arrived in American society with clear political goals and reform initiatives—what Dirk Hoerder refers to as "cultural baggage," from their points of departure. ${ }^{1}$ Interpreted in this way, chronicles of the immigrant experience consider actions in their homeland as carrying equal weight and profound determination for their actions and political involvement in their new place of residence. This project has shown in particular that on both sides of the Atlantic, the forty-eighters and their supporters believed that from strong political involvement as well as active push for reform, they could contribute to their new homeland by completing the ideals of the American Republic.

The full effect of the Revolutions of 1848 on the United States was delivered and expanded by forty-eighters and other politicized Germans who shared common values. Their individual agency, means, and mechanisms toward fulfilling a progressive republic in the German Confederation and a couple of years later in the United States contains many parallels within these contexts. The emboldened efforts of these radicals in both locations, however, are not clearly evident when scholars simply observe the effects of the Revolutions of 1848 on a surface level, or concentrate on the most significant debates of the Vorparlament. Civic involvement by way of the vote, economic solidarity, and democratic reform propelled this population to the streets, in support of radical figures like Friedrich Hecker, Karl Heinzen, and others who heard their calls. These demands, confrontations, as well as successes are best seen

\footnotetext{
${ }^{1}$ Dirk Hoerder, Migrations and Belongings: 1870-1945 (Cambridge: Belknap Press of Harvard University Press, 2012): 41 .
} 
on a smaller scale of study, in towns where radical leaders operated closely with ordinary activists and reached pinnacle turning points in their political positions.

The example of Karl Heinzen and his group of like-minded writers proves that the Revolutions of 1848 and its disappointing conclusion served a radicalizing factor in itself. Its outcomes convinced Heinzen that anti-elite violence was the only reliable instrument for reform. Though he was compelled to flee Europe for these beliefs, Heinzen remained resolute in these opinions as well as other controversial positions acquired after his permanent settlement in the United States. His attempts for reform, aided by his leadership and organizational skills, were achieved in partnership with the press, local labor unions and local German societies. Furthermore, life in the United States, in particular, brought German radicals face to face with slavery. The enslavement of African Americans generated new human rights agendas and political activism among the forty-eighters and their supporters. The same republican values that shaped their political activism in Central Europe only grew in scope and political action once they realized the disturbing shortcomings of the American Republic.

In the German Confederation and in the United States, working-class advocates and defenders of skilled trades had allied themselves with these unyielding figures since the Revolutions. In Baden and other Central European states, tens of thousands of ordinary figures joined radicals in protest of their exclusion from politics and abuses of state power as well as their loss of control over craft industries. They violently objected to the exclusionist policies of their monarchical governments, demanded representation in state parliaments, and largely endorsed radical forty-eighters' messages of progressive reform. This oppressed status in their homeland transformed into a strong immigrant identity once these and like-minded communities arrived in the United States, retaining their beliefs and visions for economic and political reform. 
As Bruce Levine explains, forty-eighters like Karl Heinzen and the thousands of German laborers involved in the first labor unions once again aspired to engage in and influence structural change toward democratization. ${ }^{2}$ According to Elliott Shore, "no people has more readily posed the question of what America is and how it acts in the world" as this generation of German immigrants. ${ }^{3}$ Indeed, they considered themselves harbingers of the republican philosophy in a country that had not fully realized complete republicanism due to the federal government's passive reactions to the brutal realities of slavery and industrial labor.

In both areas, radicals utilized similar methods to construct this massive following. Newspapers and a rapidly expanding press culture proved major lines of continuity in regard to politicization in the German Confederation and later in the United States. Sperber points out that a revolutionary press continued to serve as the mouthpiece for local forty-eighter leaders like Heinzen. An emerging culture of opinion-oriented newspapers exposed millions of German speakers to his and his contemporaries' messages for progress. ${ }^{4}$ In addition, these political newspapers urged readers to treat their shared republican ideals seriously, and to assert their identity as citizens. Germans did this in Baden by pushing for enfranchisement, and they also executed this mission in the United States by proclaiming and defending their right to vote, as exemplified on a notorious election day in Louisville in 1855.

Yet the press as well as workers' associations and civic societies as methods of outreach and organization also earned revolutionaries negative attention on the part of the dominant forces in society, whether it was a powerful aristocracy or the rising Know-Nothing party of the early

\footnotetext{
${ }^{2}$ Bruce Levine, "Free Soil, Free Labor, and Freimanner: German Chicago in the Civil War Era," in German Workers in Industrial Chicago, 1850-1910: A Comparative Perspective. Hartmut Keil and John B, Jentz, eds. (DeKalb, Ill: Northern Illinois University Press, 1983): 166.

${ }^{3}$ Elliott Shore, "Introduction: A New Look at the Nineteenth Century," in The German-American Encounter: Conflict and Cooperation Between Two Cultures, 1800-2000. Frank Trommler and Elliott Shore, eds. (New York: Berghahn Books, 2001): 3.

4 Jonathan Sperber, The European Revolutions, 1848-1851 (Cambridge: Cambridge University Press, 2005):160.
} 
1850s. Protesters, however, stood their ground against such unsympathetic sentiment as radicals resolved that death and persecutions were risks to be taken in the battle for enfranchisement. In Baden, revolutionists did not put down their weapons or abandon the barricades until Prussian troops had left them no choice by the summer of 1849. Six years later, the AnzeigerLouisville's leading German newspaper-urged its audience to stifle their fears of nativist mobs and Know-Nothing gangs and participate in a local election despite those dangers. Louisville's German and Irish communities paid dearly for this commitment, losing loved ones, homes, and businesses. In each instance, however, these radicals never willingly surrendered, but were rather suppressed under the weight of their enemies' desire to silence their efforts to exercise and promote their rights in each oppressive juncture.

The Louisville Platform is perhaps the best example of an immigrant population defending itself against the nativist party's hateful rhetoric. It demonstrated the expansion of Heinzen's political commitment to human rights by denouncing slavery and calling for free Negroes, immigrant and women's rights. Heinzen's proposals for fundamental reforms, evident within the Platform, ultimately cast German immigrants as untrustworthy and dangerous elements in the eyes of their enemies. Nativists and Know-Nothing supporters felt strongly that this foreign born outspoken group did not express the correct "Americanism.” In fact, they interpreted these German groups' legitimate attempts to improve or realize such republican reforms as rather a way to erode treasured national moral values. These Germans represented a fundamental threat. Furthermore, by the retention of their language, ethnic customs, and even religious beliefs, Germans as an immigrant group appeared to undermine and not enhance the country's democratic orientation. 
By coming to the United States and sharing and expanding upon their visions of the Revolutions of 1848, radicals like Heinzen and the groups with which they were involved considered themselves deliverers of that progressive reform. In their minds, Americans needed the assistance of foreign ideas and perspectives to fulfill what they considered the country's destined role in the world as an exemplar of total democracy. In German immigrant communities, political activism and ethnic orientation remained united. No individuals highlighted throughout this study indicated that assimilation, or natural "Americanization" of the foreign-born, was key to the progress of reform in the United States. As Hartmut Keil explains, these hundreds of "Little Germanies" scattered among towns of all sizes in the country served a preserved language and heritage. ${ }^{5}$ Most importantly, adds Shore, "these communities were to be the realization of what could have" been had the revolutions succeeded. ${ }^{6}$ Therefore, they were considered crucial sites of organization and cultural retainment to protect.

In other words, politicized Germans proved willing to work toward such goals alongside different ethnic groups as well as American allies, though never considered abandoning their customs, language, and values as they became "German-American." Rather, these radicals believed that conditions would improve for the foreign-born once native-born Americans became and behaved more like them by adopting the former group's values and views. Such attitudes earned figures like Heinzen positive and negative attention, as he and his cohort angered and inspired just as many people across the country. Discriminatory measures like temperance and sabbatarian legislation as well as deadly acts of voter suppression by Know-Nothing gangs nationwide blatantly sought to obstruct the rising influence of these figures and the endurance of

\footnotetext{
${ }^{5}$ Hartmut Keil, "German Immigrant Workers in Nineteenth-Century America: Working Class Culture and Everyday Life in an Urban Industrial Setting," in America and the Germans, Volume I: An Assessment of a Three-Hundred Year History. " Frank Trommler and Joseph McVeigh, eds. (Philadelphia: University of Pennsylvania Press, 1985): xvii.

${ }^{6}$ Shore, "Introduction," 4.
} 
their immigrant communities. ${ }^{7}$ James Bergquist points out that some German immigrant figures, such as Heinzen, advocated total political separation from Anglo-Americans because neither party in power at the time - the Democrats or the Know-Nothings - completely "represented German-American values" and both housed nativists in their corners. ${ }^{8}$ Essentially, according to Shore, German immigrants wanted no part of a political organization that did not appeal "to ethnic identity and cultural preservation."9

Even after the events in Louisville on August 6th, 1855, one of the most violent and destructive instances of voter suppression against immigrants, German communities continued to express their determination to survive and thrive. Many moved away—-some with dignity and some with shame - from this sight of devastation, just as thousands of forty-eighters and ordinary workers had done after 1849 . They never willingly surrendered the visions for egalitarianism that had initially propelled them to the United States. Lasting into the twentieth century, politicized radical Germans participated in efforts toward the abolition of slavery, workers' unions, women's rights organizations, and combated temperance legislation in cities and towns of various size across the country. With these actions, Kathleen Neils Conzen argues, German-Americans had constructed "a principled defense of the legitimacy of ethnic cultural difference" in the United States, which only further secured the durability of these communities. ${ }^{10}$ For example, in many states, German remained the second language spoken in schools. German newspapers, secular or religious, endured and enjoyed mass audiences as

\footnotetext{
${ }^{7}$ Bruce Levine, The Spirit of 1848: German Immigrants, Labor Conflict, and the Coming of the Civil War (Urbana: University of Illinois Press, 1992): 89-90.

8 James Bergquist, "The Forty-Eighters: Catalysts of German-American Politics," in The German-American Encounter: Conflict and Cooperation Between Two Cultures, 1800-2000. Frank Trommler and Elliott Shore, eds. (New York: Berghahn Books, 2001): 29-30.

${ }^{9}$ Shore, "Introduction," 4.

${ }^{10}$ Kathleen Neils Conzen, "Phantom Landscapes of Colonization," in The German-American Encounter: Conflict and Cooperation Between Two Cultures, 1800-2000. Frank Trommler and Elliott Shore, eds. (New York: Berghahn Books, 2001): 17-18.
} 
sources of pride for the community. Local Turnverein, singing societies, and theatre troupes entertained local neighborhoods in their native tongue for almost a century. German cuisine such as sauerkraut, cabbage, sausages, and even beer consumption became popular. Most importantly, in local politics, radical Germans served as major proponents of the idea that the federal government had a responsibility to intervene on behalf of employees in confrontations with employers during a time when laborers possessed few liberties at all. Furthermore, German individuals like Heinzen were some of the first supporters for the emancipation and complete equality of African Americans before the law.

This flourishing German scene endured until it was rapidly and aggressively ripped away from the multicultural and multilingual orientation of the United States following the country's entry into the First World War. Newspapers went bankrupt, the German language was shunned in public schools, cultural societies disbanded, and hundreds of thousands of inhabitants within "Little Germanies" were forced to adopt the identity of "enemy alien." Some German organizations, however, survived this period of mass paranoia and state-sanctioned persecution. Louisville's Anzeiger endured for two decades longer, serving as an anchor for German culture during an era when they were again under considerable attack from a new generation of nativists.

Thus, German immigrant communities and their activist leaders resisted calls for total assimilation into an Anglo-American dominated culture for decades. They continued to retain and celebrate their heritage and language in the years prior to the First World War, when the European conflict designated all Germans as anti-American. Despite their history of resilience and preservation, German communities across the country never regained the cultural organizations and German-language press that they enjoyed prior to the First World War, 
therefore the vibrant history of this immigrant population has largely been blended into a narrative of assimilation.

This project, therefore, also questions traditional narratives of immigration and assimilation in the nineteenth-century United States, as it reveals a history of German-American resistance to calls for assimilation, largely defeated by 1918. In doing so, it contributes to a range of recent works that challenge former traditional narratives of inevitable immigrant assimilation in the United States. This "traditional narrative" includes beliefs that foreign-born groups lacked agency in their new homeland, or that the process of assimilation — of abandoning cultural expression, language, and even religious customs of the "Old World"-was and remains a natural and necessary component of Americanization. In contrast, this study encourages scholars to reinterpret the immigrant experience as a whole. In other words, immigrants recognized the hypocrisy and deficiencies in the American Republic. Through civic involvement such as the press, the vote and the formation of political associations, these immigrant populations proved determined to play a key role in and contribute to the realization of a better republic that reflected their values and visions.

The object of these politicized Germans was never to "become like" the native-born Americans who surrounded them and dominated government and politics. ${ }^{11}$ Rather, Germanimmigrant communities in the aftermath of the Revolutions of 1848 sought to "acculturate" their language and customs with the majority of society as well as fulfill their goals for real democracy within pre-existing outlets for reform. ${ }^{12}$ In doing so, radical figures like Heinzen inspired and aided the development of a network of political societies within hundreds of large American cities and small towns. These groups sought to transform and improve undesirable

\footnotetext{
${ }^{11}$ Harzig and Hoerder, What is Migration History? (Cambridge: Polity Press, 2009):102.

${ }^{12}$ Harzig and Hoerder, What is Migration History? 104.
} 
conditions in a country with the materials and opportunities to implement such change, despite challenges from a strong nativist party. This work has highlighted republican visions and accomplishments achieved in mid-century German communities, the ideas and values pushed by their most outspoken leaders, as well as the trials that they faced in the execution of those reforms.

Shared values, ideas, and the means within immigrant communities in the United States can be identified by first exploring where they originated and even radicalized as in the expanding politicization in German Central Europe prior to and during the Revolutions of 1848 and its violent conclusion within Baden in 1849. Displaced from these initial sites of defiance, hundreds of revolutionaries like Karl Heinzen and their thousands of supporters inspired and encouraged political engagement in American cities like Louisville and beyond. According to Conzen, these groups were "intent upon politically mobilizing German and non-Germans alike in the cause of universal liberty," a term often used by Heinzen himself. ${ }^{13}$ Tracing the political engagement and major reform efforts of this activist population from 1848 to 1849 sheds light on their later persistence against voter suppression, anti-immigrant displays and remarks, as well as other methods of intimidation and persecution in the United States. Louisville's nativist leaders and their supporters, threatened by these outspoken and reform-oriented newcomers, were determined to silence their voices on a local election day in August of 1855. This story, in highlighting the violent repercussions of the clash between politicized German immigrants and hostile nativists, illustrates the visions and tribulations of immigrant societies in the United States to reveal the challenge of German radical republicanism to American politics and values.

\section{Appendix A: The Louisville Platform}

\footnotetext{
${ }^{13}$ Conzen, "Phantom Landscapes of Colonization," 17. Emphasis mine.
} 


\section{To All True Republicans in the Union}

The free Germans of the union have found it necessary to organize themselves for the purpose of being able to exercise a political activity proportional to their number and adapted to their principles. There is a fair prospect for success for such an organization, and in this hope the free Germans of Louisville, Ky. have proceeded to lay down the following platform, which they unanimously agreed upon in a mass meeting and make it known to the public at large as the standard of their political course.

At the same time they have entrusted the undersigned committee with the charge of recommending said platform together with its introduction to their sympathizing countrymen for them to join upon, and of communicating it to the members of Congress and those of the political press for an honest examination and fair criticism.

The undersigned committee hereby discharge their commission, and trust, that it will also be thought worthwhile to inform our fellow-citizens of a different language of the principles and endeavours of the numerous free Germans, and to ask them to allow such principles and endeavors that attention which we are convinced they deserve. The free Germans furthermore indulge in the hope that it will be possible to form a powerful reform party, embracing all who want that liberty now so much endangered, and the progress and happiness of this our common republic to be secured on principles lasting, truly republican and democratic. They wish, after having completed their organization, to establish--with the aid of their liberal-minded fellowcitizens--such a power of votes as to be able in 1856 to decide the victory in favor of a party of true reformers.

The Editors of public papers who will enter into a discussion of the platform--which we invite them to do "sine ira et studio" that is, before all, without narrow minded nativism and blind party spirit--are politely requested to favor us with a copy of the number or numbers, containing their arguments. Address Chas. Heinzen, Editor of the Pioneer, Louisville Ky., letterbox 1157 .
Bürgeler
Stern
L. Wittig
B. Domschke
Ch. Heinzen

\section{UNION OF THE FREE GERMANS}

"Liberty, prosperity, and education for all!" This is the great principle of the revolution which all free Germans, as a summary expression of their designs and efforts, brought with them from the old country. 
But with this they did not erect any new political theory, as we find the same principle set forth in other words in the Constitution of the United States and in the Declaration of Independence of 1776, which acknowledges "that all men are created equal, that they are endowed with inalienable rights," and that to these belong "life, liberty, and the undisturbed pursuit of happiness."

But have these solemnly proclaimed rights been verified in the United States? Only in part, and it has become necessary to remind those of them, whose first duty it was to watch over them.

Instead of securing liberty to all, more than three million of human beings have been condemned to slavery, and efforts are daily made to increase their number.

Instead of making liberty, prosperity, and education accessible to every one, they are rather made a privilege for those classes and races who control the legislation and administration of the country.

We behold speculation instead of fulfillment of duty, corruption instead of virtue and reaction in possession of power.

We see the republic degraded abroad by unpunished outrages, committed upon American citizens; we see the republic denounced at home by the treacherous coalitions and understandings with the chiefs and agents of European despotism.

We see the representatives of a republican people in open league with the darkest of all powers, the deadly enemy of all liberty, the power of the Pope and the Jesuits.

We see in Congress every measure in favor of the privileged few advanced, and every measure in favor of the people frustrated.

We see the means of the nation made booty by avaricious defenders, instead of being applied for the public benefit.

We see lawlessness and crime on the increase because the legislative and executive authorities are busier with their own selfish projects than with the true interests of the people and satisfied to cover with a religious varnish the destitute moral education.

We see the republic sentiments of the people demoralized and blunted by compromiselaws, which scorn and defy humanity, right and the Constitution as well as other agreements which should constitute an eternal bulwark for liberty when feloniously attacked.

In short, we see the main principles set forth above, which were framed by the great founders of this republic as a guide for its future development, and which we fully concur in, renounced and supplanted in all important and final questions by a policy inimical to the true interest of the people. 
This thing must be stopped if we will avoid that fate of this republic which Jefferson already feared and for which he "trembled." What treacherous representatives of the people fail to do, the PEOPLE must amend themselves, for as all rights originate with the people, so all laws must be created by them.

The free Germans, as an important number of United States' citizens, as faithful adherents to republican liberty and as jealous wardens of Democratic rights, will fulfill their duty to their adopted country by forming an organization for the purpose of carrying into full effect those grand principles of the Declaration of Independence and of the Constitution, and to oppose all who jeopardize them.

By organizing for such purpose among themselves they do by no matter intend to separate themselves from the Anglo-Americans, it being on the contrary THEIR VERY PURPOSE TO CONTRACT AN EFFICIENT ALLIANCE WITH ALL TRUE AMERICANS, I.E. ALL TRUE REPUBLICANS; but their preliminary separated organizations is only a practical necessity imposed upon them by the difference in language and has the object to lead at once many of the older German emigrants to a more honorable position, who hitherto under false names and pretexts were deceived and used as tools by conscienceless party demagogues.

We express our principal aim and its motives in the following platform, intended to serve us as a standard in the performance of our republican rights. In the elections, be they national, City, County, or State elections, we shall without any regard to name, authorities and conventions, support only such men and parties, as will pledge themselves to the support of our principles or give us the best guaranty of carrying them out.

\section{PLATFORM OF THE FREE GERMANS}

\section{1.--SLAVERY QUESTION}

Notwithstanding that we consider slavery to be a political and moral cancer, that will by and by undermine all republicanism, we deem its sudden abolition neither possible or advisable. But we, as republicans and men, demand that the further extension of slavery be no constantly urged, whilst not a single step is taken for its extermination. We demand that at length real proofs be given of the good will so often boasted of to remove the evil; that, in particular, slavery be excluded from all territories indiscriminately and forever, which measure Congress is completely entitled to pass according to the Constitution; we demand this the more as a republican Constitution is guaranteed to every new State, and slavery in truth cannot be considered a republican element or requisite. We further demand, that all and every one of the laws indirectly transporting the principle and the influence of slavery in and upon free States, namely: the Fugitive Slave Law, shall be repealed as demoralizing and degrading, and as contrary to the rights and to the Constitution; we finally demand that in all national affairs the principle of liberty shall be strictly maintained and even in the several States it be more and more realized by gradual extermination of slavery.

\section{2.--RELIGIOUS QUESTIONS}

We consider the right of free expression of religious conscience untouchable as we do the right of free expression of opinion in general; we therefore accord to the believer the same liberty 
to make known his convictions, as we do the non-believer, as long as the rights of others are not violated thereby. But from this very principle of liberty of conscience we are decidedly opposed to all compulsion inflicted to dissenting persuasions by laws unconstitutionally restricting the liberty of expression. Religion is a private matter, it has nothing to do with policy; hence it is despotism, to compel citizens by political means to religious manifestations or omissions contrary to their private persuasions. We, therefore, hold the Sabbath laws, Thanks-givings-days, prayers in Congress and Legislatures, the oath upon the bible, the introduction of the bible into the free schools, the exclusion of "Atheists" from legal acts, etc., as an open violation of human rights as well as of the Constitution and demand their removal.

But whilst no POLITICAL interference should inflict compulsion to RELIGIOUS liberty, still less it should be lawful to use the liberty of RELIGION as a pretext and instrument for organizations dangerous to the country, to create States within the State, especially when such organizations are conducted under the leading influence of foreign potentates. We, therefore, consider the recognition of the Roman Hierarchy in this country as anti-republican, its position as anti-Democratic and its continuance as highly dangerous.

Our Catholic as well as our Protestant fellow-citizens have the right, to...and...teachers themselves in a Democratic manner, but no.....has or should be allowed to have the right, to install them here as his subjects and tools. The Catholic priests on account of their subordination and allegiance to their romish superior, cannot take upon themselves even the...of citizens, but on the other hand, make the most dangerous... of the...of citizens by transferring church-property, sometimes amounting to millions, and property belonging to their parishes or dioceses upon their names and then by means of money and wealth, strengthening their ecclesiastical influence to the most dangerous degree of power. If we consider, that every romish priest is an officer and every obedient Catholic is a subject to the Pope, and that the Pope--the murderer of the Roman republic--must be a natural enemy of the North American republic, then the inavoidability of the conflict is evident which this country prepares for itself by the recognition of a roman Hierarchy and the toleration of their organizations of power. The consequences of such a contradictory and mischievous relation...the more manifestly before the eyes of every one, as the leading organs of the romish Hierarchy openly establish the dogma, that democracy is Anti-Catholic and that every Catholic is bound by the salvation of his soul to overthrow the Constitution of the United States if the Pope orders him. Such an open avowal of murderous intentions against the republic cannot be misinterpreted by even the most short-sighted, and it is treason to favor them.

If the Pope, the chief of the Catholic Hierarchy has the right to appoint his agents here, then the Emperor of Russia, as the chief of the Greek Church has the same right, and then the sovereignty of the American people is an entire falsehood.

It is our opinion that the position of the Popish officers in this country, in this case, comes under those provisions of the Constitution according "to which it is not allowed, to accept offices or titles from princes and foreign States, and according to which high treason is committed by him who adheres to the enemies of the United States or who favors or helps them."

We, therefore, demand for the interest of the republic that an end shall be put to the exercise of the power of the Pope by the instrumentality of Bishops and other agents within the 
United States, that his interference in the affairs of our citizens here be energetically prevented and that the order of Jesuits be treated as a declared enemy of the republic.

We furthermore demand a law, according to which no one shall be allowed to remain in the United States over five years without rendering an oath to uphold the Constitution.

\section{3.--MEASURES FOR THE WELFARE OF THE PEOPLE}

As the foremost of such measures we consider the free cession of Public Lands to actual settlers; to occupy nature, the soil as exclusive property, this no individual has a right to do; it is, for the time, the common principal fund of that population, which inhabits it, and any body willing to cultivate it has an equal right to appropriate a share of the soil, as far as is not disposed for purposes of common interest. It is high time that the ruineous traffic with the Public Lands should be abolished, that the wasting of them by speculation, should cease, and the indigent people enter upon their rightful possession.

But if this end shall be fully attained, it will be required to aid poor colonists, at their first settlement with national means, lest said measure prove useless for these very persons who most need it.

In the closest connection with the land reform question, stands that of emigration, which by its general importance, should be raised to the rank of a national affair, and for which a special office of colonization and emigration should be created as a particular department of the U.S. Government. Such a board would have to provide for the various interests of emigrants, who are now helplessly exposed to so many sufferings, wrongs and abuses, from the place of embarkation in Europe to the place of their settlement in America. North America is neglecting herself when neglecting the emigration, for emigration is the mother of this republic.

The admission to citizenship must be rendered as easy as possible to the emigrants.

The welfare of a nation cannot be generally and permanently assured unless its laboring classes be made independent of the oppression of the capitalist. Labor has an incontestable claim to the value of its products. Where it is prevents by the want of the necessary capital, to secure this claim, it is of course refer to an alliance with capital of others. But if no just agreement can be obtained by this association with the capitalist, then the State as the arbitrator of all contending interests, has to interfere. This must either aid the association of working men by credit banks, or mediate between the claims of the laborer and the capitalist, by fixing a minimum of wages equalling the value of the labor, and a maximum of labor answering the demands of humanity. The time of labor shall not exceed ten hours per day.

In letting out State contracts the preference should be given, if it can be done without running a risk, to associations of workmen, rather than to single contractors. But when given to a single contractor, the latter ought to give security for proper wages to the workmen employed by them.

Labor being the only creator property, the laws of inheritance ought to be modified so far as to exclude the possibility of an unproductive monied or land aristocracy. 
In order to enjoy "life, liberty and happiness," all indiscriminately must have the use of free schools for all branches of education, in which, wherever a sufficient number of Germans live, a German teacher should be employed.

We also regard the greatest possible reduction of postage and especially the gratuitous forwarding of newspapers and pamphlets as a necessary means for facilitating popular instruction.

In order that the attainment of justice may no longer remain a privilege for the possession of money, justice must be dispensed without fees.

An equal necessity is the radical reform of the judicial system, and the framing of a popular code of laws, the law being at present a mystery for the people and a means to deceive them.

\section{4.--CONSTITUTIONAL QUESTIONS}

Considering, as we do, the American Constitution as the best now in existence, we yet think it neither perfect nor unimprovable. In particular we hold the following amendments and additions likewise acceptable for the State Constitution as timely and proper means to check the prevailing corruption, to wit:

1. All elections, without any exception, should...directly from the people.

2. Any eligible citizen of any State may be elected as member of congress by the citizens of any other State, and likewise many any eligible dominion of any county be elected by the citizens of any other county for a member of the State Legislature.

3. Any representative and officer may at any time be recalled by the majority of his constituent and replaced by another.

\section{5.--FREE TRADE}

We decidedly prefer the principle of free trade and will support it in all cases, where it may be carried through without disadvantage to the people and where reciprocity is accorded by the other side.

\section{6.--INTERNAL IMPROVEMENTS}

We consider it self-understood that all public works and improvements that are of a national interest, not mere State or local necessities, must be carried out by national means, and we reckon among such the railroad to the Pacific.

\section{7.--FOREIGN POLICY}

The policy of neutrality must cease to be an article of our creed and ought to be abandoned as soon as contrary to the interests of North America. The rights of American citizens and emigrants having declared their intention to become citizens, must the more energetically be 
protected in foreign countries, since every American appears to monarchial and despotical governments as a representative of revolution against despotism, and this republic ought to honor this point of view as the only one worthy and legitimate.

\section{8.--RIGHTS OF WOMEN}

The Declaration of Independence says, that "all men are born equal and endowed with inalienable rights and to those belong life, liberty, and the pursuit of happiness." We repeatedly adopt this principle and are of the opinion that women, too, are among "all men."

\section{9.--RIGHTS OF THE FREE NEGROES}

In free States the color of the skin cannot justify a difference of legal rights. There are not born two men of equal color, but still less two men of unequal rights.

\section{0.--PENAL LAWS}

In is our opinion, that all penal laws can only have the purpose of correction, but never the absurd purpose of expiation.

We, therefore, consider penalty of death, which excludes the possibility of correction, to be as irrational as barbarous.

\section{1.--MILITARY LAWS}

We believe the solider of a republic to be nothing else but a citizen armed for protection of his country, and cannot conceive how this position may require a particular jurisdiction, contradicting republican sentiments of justice. We, therefore, deem it republican and democratic that military jurisdiction should be abolished at least during the time of peace.

\section{2.--LIMITS OF LEGISLATION}

The laws are established in order to settle the right and to prevent the wrongs in the relation of men to men. The interference of law into the sphere of the individual, as far as he does not get into collision with others, is an unjustifiable trespass. We therefore consider the temperance laws--apart from their inefficiency and unconstitutionality--to be tyrannical encroachments upon individual liberty, and narrow-minded manifestations of an entire misconception of the legislative duties.

By assuring "Liberty, prosperity and education to all," temperance laws will be made as superfluous as the penalty of death. 


\section{Bibliography}

\section{Primary Sources}

\section{$\underline{\text { Archival Material }}$}

Filson Club Historical Society Archive, Louisville, Kentucky

Allawyn, Lewis Walter. Additional Papers, 1891-1941.

Green, Norvin. Norvin Green Papers, 1802-1892.

Heffernan, Michael. "Bloody Monday in Louisville." Michael Heffernan Memoirs.

Johnson, Josiah Stoddard. Josiah Stoddard Johnson Scrapbook \#3.

Rowell, Elsie Alma. Elsie Alma Rowell Papers, 1938-1941.

Speed, James. The Speed Family Papers, 1813-1981.

\section{Newspapers}

Baltimore Sun, 1854

Boston Liberator, 1854

Der Wahrheits-Freund, 1855

Louisville Daily Courier, 1853-1855

Louisville Journal, 1853-1855

National Intelligencer (Washington, D.C.), 1854

New York Daily Times, 1855

Wheeling Daily Intelligencer, 1855

$\underline{\text { Books }}$

Berthold, Carl. "Louisville, June 3, 1854." In News from the Land of Freedom: German Immigrants Write Home. Edited by Walter D. Kamphoefner, Wolfgang Helbich, and Ulrike Sommer. Ithaca: Cornell University Press, 1988: 299-334.

Berthold, Carl. "St. Louis, February 2, 1853." In News from the Land of Freedom: German Immigrants Write Home. Edited by Walter D. Kamphoefner, Wolgang Helbich, and Ulrike Sommer. Ithaca: Cornell University Press, 1988: 299-334.

Berthold, Carl. "Louisville, October 22, 1855." In News from the Land of Freedom: German Immigrants Write Home. Edited by Walter D. Kamphoefner, Wolgang Helbich, and Ulrike Sommer. Ithaca: Cornell University Press, 1988: 299-334.

Boernstein, Henry. Memories of a Nobody: The Missouri Years of an Austrian Radical, 1849-1866. Edited and translated by Steven Roward. St Louis: Missouri Historical Society, 1997. 
Bogan, Pastor. "Instruction for German Immigrants, 1850.” In America 's Immigrants: Adventures in Eyewitness History. Edited by Rhoda Hoff. New York: Henry Z. Walch, Inc., 1967: 62-65.

Campbell, W.W. "New York Congressman, before the House of Representatives, April 8, 1846." In American Nativism, 1830-1860. Edited by Ira M. Leonard and Robert D. Parmet. New York City: Van Nostrand Reinhold Company, 1971.

“Contents of a Carpenter's Tool Box." C.L. Fleischmann. Erwerbszweige, Fabrikwesen und Handel der Vereinigten Staaten von Nordamerika, mit besonderer Rücksicht auf deutsche Auswanderer. Stuttgart, 1850. Composed by Hartmut Keil and John B. Jentz: 64-66.

“German Emigration.” Chambers Edinburgh Journal, June 20, 1846. In The Ordeal of Assimilation: A Documentary History of the White Working Class. Composed by Stanley Feldstein and Lawrence Costello. Garden City, NY: Anchor Press, 1974: 387-89.

Germans to America: Series II, vol. 5, July 1847-March 1848. Edited by Ira A. Glazier. Wilmington: Scholarly Resources, Inc., 2003.

Heck, Nicholas and Angela. "New York City, July 1, 1854." In News from the Land of Freedom: German Immigrants Write Home. Edited by Walter D. Kamphoefner, Wolfgang Helbich, and Ulrike Sommer, eds. Ithaca: Cornell University Press, 1988: 367-382.

Heinzen, Karl. Des Helden des deutschen Kommunismus. Bern, 1848.

Heinzen, Karl. Die preußische bürokratie. Darmstadt, 1845.

Heinzen, Karl, and Gustav Struve. Die Schilderhebung Der Deutschen Republikaner Im April 1848. Strassburg: Schmidt und Grucker, 1848.

Heinzen, Karl. Deutsche Eine Republik. Belle-Vue: J. Kohn, 1848.

Heinzen, Karl. Erlebtes...Boston: Selbstverlag des verfassers, Volumes 1 and 2, 1864-1874.

Heinzen, Karl. Mord und Freiheit. Indianapolis: H. Lieber, 1881.

Heinzen, Karl, and Karl Schmemann. Teutscher Radikalismus in Amerika: Ausgewählte Abhandlungen, Kritiken und Aphorismen aus den Jahren 1854-1879. Milwaukee: Freidenker Pub. Co., 1890. 
Heinzen, Karl. The Rights of Women and the Sexual Relations. Chicago: Charles H. Kerr \& Company, 1891. Originally published in 1852.

Heinzen, Karl. "What is Real Democracy? Answered by an Exposition of the Constitution of the United States," 1871.

Henretta, James A., and Jürgen Heideking, eds. Republicanism and Liberalism in America and the German States, 1750-1850, Cambridge: Cambridge University Press, 2002.

Lenz, Christian. "Louisville, May 29, 1855." In News from the Land of Freedom: German Immigrants Write Home. Edited by Walter D. Kamphoefner, Wolgang Helbich, and Ulrike Sommer. Ithaca: Cornell University Press, 1988: 122-148.

Lenz, Christian. "Louisville, October 22, 1855." In News from the Land of Freedom: German Immigrants Write Home. Edited by Walter D. Kamphoefner, Wolgang Helbich, and Ulrike Sommer. Ithaca: Cornell University Press, 1988: 122-148.

Lincoln, Abraham. Collected Works, Vol. 2. New Brunswick: Rutgers University Press, 1953.

"Louisville Platform." In The German-American Forty-Eighters, 1848-1998. Edited by Don Heinrich Tolzmann. Indianapolis: Max Kade German-American Center, 1998.

"Memorial of the Officers of the German Society of the City of New York to the New York Legislature, Demanding a Share of the Head Tax Receipts." Assembly Democrat 165, 1848. In The Ordeal of Assimilation: A Documentary History of the White Working Class. Composed by Stanley Feldstein and Lawrence Costello, comps.Garden City: Anchor Press, 1974: 3-5.

Mueller, Jacob. Memories of a Forty-Eighter: Sketches from the German-American Period of Storm and Stress in the 1850s. 1st English ed. Cleveland, OH: Western Reserve Historical Society.

"Platform of the Principles of the American Party in Connecticut, adopted June 28th, 1855." In American Nativism, 1830-1860. Edited by Ira M. Leonard and Robert D. Parmet. New York City: Van Nostrand Reinhold Company, 1971: 143-145.

Ruetenik, H. J., and Harold Jantz Collection. Berühmte Deutsch Vorkämpfer für Fortschritt, Freiheit und, Friede in Nordamerika: Von 1626 bis 1888. Cleveland: Forest City Bookbinding Co., 1888.

Schwenck, Nicholas. "Chicago, September 9, 1855." In German Workers in Chicago: A 
Documentary History of Working-Class Culture from 1850 to World War I. Composed by Hartmut Keil and John B. Jentz. Urbana: University of Illinois Press, 1988: 24-33.

Schurz, Carl. "Reminiscences of Carl Schurz." 3rd edition (New York, 1908), 257. In The Ordeal of Assimilation: A Documentary History of the White Working Class. Edited by Stanley Feldstein and Lawrence Costello. Garden City, NY: Anchor Press, 1974: 96-98.

Stierlin, Ludwig. Der Staat und die Stadt Louisville unter besonderer Berücksichtigung des deutschen Elementes. Louisville: Louisville Anzeiger, 1873.

"Testimony as to the Origins of the Riots in the City of Louisville, KY." Hull \& Brother Printers, 1855.

Weitz, Martin. "Rockville, July 29, 1855." In News from the Land of Freedom: German Immigrants Write Home. Edited by Walter D. Kamphoefner, Wolfgang Helbich, and Ulrike Sommer. Ithaca: Cornell University Press, 1988: 335-366.

Zakrzewska, Marie Elizabeth. Marie Elizabeth Zakrzweska: A Memoir. Boston: New England Hospital for Women and Children, 1903.

\section{Secondary Sources}

Adams, Willi Paul. "Ethnic Leadership and the German-Americans." In America and the Germans, Volume I: An Assessment of a Three-Hundred Year History. Edited by Frank Trommler and Joseph McVeigh. Philadelphia: University of Pennsylvania Press, 1985: $146-59$.

Anbinder, Tyler. Nativism and Slavery: The Northern Know-Nothings and the Politics of the 1850s. New York: Oxford University Press, 1992.

Anderson, Kristen Layne. Abolitionizing Missouri: German Immigrants and Racial Ideology in Nineteenth-Century America. Baton Rouge: Louisiana State University Press, 2016.

Baker, Thomas Stockham. Young Germany in America. Philadelphia: P.C. Stockhausen, 1897.

Baldwin, "The Public Image of Germans in Louisville and in Jefferson County, Kentucky, 1840-72." Yearbook of German-American Studies 29 (1994): 83-90.

Barkai, Avraham. Branching Out: German-Jewish Immigration to the United States, 1820-1914. 
New York City: Holmes and Meier, 1994.

Berger, Helge, and Mark Spoerer. "Economic Crises and the European Revolutions of 1848." The Journal of Economic History 61, no. 2 (2001): 293-326.

Bergquist, James. "German Communities in American Cities: An Interpretation of the Nineteenth-Century Experience." Journal of American Ethnic History 4, no. 1 (1984): 930.

Bergquist, James. "The Forty-Eighters: Catalysts of German-American Politics.” In The German-American Encounter: Conflict and Cooperation between Two Cultures, 18002000. Edited by Frank Trommler and Elliott Shore. New York: Berghahn Books, 2001: 22-36.

Bessner, Daniel, and Michael Stauch, "Karl Heinzen and the Intellectual Origins of Modern Terror." Terrorism and Political Violence 22 (2010): 143-76.

Blackbourn, David, and Geoff Eley. The Peculiarities of German History: Bourgeois Society and Politics in Nineteenth-Century Germany. Oxford Oxfordshire: Oxford University Press, 1984.

Blackbourn, David. The Long Nineteenth Century: A History of Germany, 1790-1918. New York: Oxford University Press, 1998.

Brancaforte, Charlotte Lang. The German Forty-Eighters in the United States. New York: Peter Lang, 1989.

Bretting, Agnes. "Organizing German Immigration: The Role of State Authorities in Germany and the United States." In America and the Germans, Volume I: An Assessment of a Three-Hundred Year History. Edited by Frank Trommler and Joseph McVeigh. Philadelphia: University of Pennsylvania Press, 1985: 25-38.

Bruncken, Ernest. "German Political Refugees in the United States: 1815-1860." In The German American Forty-Eighters, 1848-1998. Edited by Don Heinrich Tolzmann. Indianapolis: Indiana University Press, 1998: 5-68.

Bühler-Dietrich, Annette. "German-American Identity in the Novels of Heinrich Börnstein and Otto Rupius." Seminar: A Journal of Germanic Studies 42, no. 3 (2006): 211-228.

Collins, Kevin and Kathleen Pellegrino. "Newspapers.” In Germans in Louisville: A History. 
Charleston, SC: Heritage Press, 2015: 81-87.

Congleton, Betty. "George D. Prentice and Bloody Monday: A Reappraisal." The Register of the Kentucky Historical Society 63, no. 3 (1965): 218-239.

Conzen, Kathleen. "Ethnicity as Festive Culture: Nineteenth-Century German America on Parade." In The Invention of Ethnicity. Edited by Werner Sollors. New York: Oxford University Press, 1989: 44-76.

Conzen, Kathleen. "German Americans and the Invention of Ethnicity." In America and the Germans: An Assessment of a Three-Hundred Year History, Vol. 1. Edited by Frank Trommler and Joseph McVeigh. Philadelphia: University of Pennsylvania Press, 1985: 131-147.

Conzen, Kathleen. Immigrant Milwaukee, 1836-1860: Accommodation and Community in a Frontier City. Cambridge: Cambridge University Press, 1976.

Conzen, Kathleen. "Phantom Landscapes of Colonization." In The German-American Encounter: Conflict and Cooperation between Two Cultures, 1800-2000. Edited by Frank Trommler and Elliott Shore. New York Berghahn Books, 2011: 7-21.

Cusick, Dennis Charles. Gentleman of the Press: The Life and Times of Walter Newman Haldeman. Louisville: University of Louisville Press, 1987.

Deusner, Charles. "The Know-Nothing Riots in Louisville," The Register of the Kentucky Historical Society 61, no. 2 (1963): 122-147.

Dobert, Eitel W. "The Radicals." In The Forty-Eighters: Political Refugees of the German Revolution of 1848. Edited by A.E. Zucker. New York: Columbia University Press, 1950.

Efford, Alison Clark. German Immigrants, Race, and Citizenship in the Civil War Era. Cambridge: Cambridge University Press, 2013.

Falk, Gary. "Manufacturing." In Germans in Louisville: A History. Charleston, SC: Heritage Press, 2015: 124-136.

Falk, Gary. "The Turners." In Germans in Louisville: A History. Charleston, SC: Heritage Press, 2015: 107-116.

Fessler, Paul. "The Political and Pedagogical in Bilingual Education: Yesterday and Today." In 
German-American Immigration and Ethnicity in Comparative Perspective. Edited by Wolfgang Helbich and Walter D. Kamphoefner. Madison: Max Kade Institute for German-American Studies, 1997: 273-91.

Fleche, Andre M. The Revolution of 1861: The American Civil War in the Age of Nationalist Conflict. Chapel Hill: University of North Carolina Press, 2012.

Foner, Eric. Free Soil, Free Labor, Free Men: The Ideology of the Republican Party Before the Civil War. New York: Oxford University Press, 1970.

Foner, Philip S. History of the Labor Movement in the United States, Vol. 1: From Colonial Times to the Founding of the American Federation of Labor. New York: International Publishers, 1998.

Fones-Wolf, Ken. "Caught between Revolutions: Wheeling Germans in the Civil War Era." In Transnational West Virginia: Ethnic Communities and Economic Change, 1840-1940. Edited by Ken-Fones Wolf and Ronald L. Lewis. Morgantown: West Virginia University Press, 2011: 4-38.

Friedrich, Carl J. "The European Background." In The Forty-Eighters: Political Refugees of the German Revolution of 1848. Edited by A.E. Zucker. New York: Columbia University Press, 1950.

Gabaccia, Donna. “'Is Everywhere No Where?' Nomads, Nations, and the Immigrant Paradigm of American History." Journal of American History 86, no. 3 (1999): 1115-34.

Grimsted, David. American Mobbing, 1828-1861: Toward Civil War. New York: Oxford University Press, 1998.

Grob-Fitzgibbon, Benjamin. "From the Dagger to the Bomb: Karl Heinzen and the Evolution of Political Terror." Terrorism and Political Violence 16, no. 1 (2004): 97-115.

Haines, David W. Safe Haven?: A History of Refugees in America. Sterling, VA: Kumarian Press, 2010.

Handlin, Oscar. "The American Scene.” In The Forty-Eighters: Political Refugees of the German Revolution of 1848. Edited by A.E. Zucker. New York: Columbia University Press, 1950.

Harper, Leslie. "Lethal Language: The Rhetoric of George Prentice and Louisville's Bloody 
Monday." Ohio Valley History 11, no. 3 (2011): 24-43.

Harzig, Christiane, and Dirk Hoerder. What is Migration History? Cambridge: Polity Press, 2009.

Hawgood, John A. The Tragedy of German-America: The Germans in the United States of America during the Nineteenth Century, and After. New York: G.P. Putnam's Sons, 1940.

Heideking, Jürgen. "Festive Culture and National Identity in America and Germany, 17601860." In Republicanism and Liberalism in America and the German States, 1750-1850. Cambridge: Cambridge University Press, 2002.

Heinz-Gerhard Haupt, and Dieter Langewiesche. "The European Revolutions of 1848: Its Political and Social Reforms, Its Politics of Nationalism, and Its Short- and Long-Term Consequences." In Europe in 1848: Revolution and Reform. Edited by Dieter Dowe. New York: Berghahn Books, 2001: 1-23.

Hewitson, Mark. “'The Old Forms Are Breaking Up, ... Our New Germany Is Rebuilding Itself”: Constitutionalism, Nationalism and the Creation of a German Polity during the Revolutions of 1848-49." The English Historical Review 125, no. 516 (2010): 1173-1214.

Hewitson, Mark. The People's Wars: Histories of Violence in the German Lands, 1820-1888. Oxford: Oxford University Press, 2017.

Hirota, Hidetaka. Expelling the Poor: Atlantic Seaboard States and the Nineteenth Century Origins of American Immigration Policy. New York: Oxford University Press, 2017.

Hoerder, Dirk. "Changing Paradigms in Migration History: From 'To America' to Worldwide Systems.” Canadian Review of American Studies 24.2 (1994): 105-126.

Hoerder, Dirk. "From Interest-Driven National Discourse to Transcultural Societal Studies." In From the Study of Canada to Canadian Studies: To Know Our Many Selves Changing Across Time and Space. Edited by Dirk Hoerder. Athabasca: Athabasca University Press, 2005: 316-26.

Hoerder, Dirk. Migrations and Belongings: 1870-1945. Cambridge: Belknap Press, 2012.

Honeck, Mischa. We Are the Revolutionists: German-Speaking Immigrants and American Abolitionists after 1848. Athens: University of Georgia, 2011. 
Huffines, Marion L. "Language-Maintenance Efforts Among German Immigrants and Their Descendents in the United States." In America and the Germans: An Assessment of a Three-Hundred Year History, Vol. 1. Edited by Frank Trommler and Joseph McVeigh. Philadelphia: University of Pennsylvania Press, 1985: 241-250.

Hutcheon, Wallace. "The Louisville Riots of August, 1855." The Register of the Kentucky Historical Society 69, no. 2 (1971): 150-172.

Jentz, John. B. "The Forty-Eighters and the Politics of the German Labor Movement in Chicago during the Civil War Era: Community Formation and the Rise of a Labor Press." In The German-American Radical Press: The Shaping of a Left Political Culture, 1850-1940. Edited by Elliott Shore, Ken Fones-Wolf, and James P. Danky. Urbana: University of Illinois, 1992: 49-62.

Kanstroom, Daniel. Deportation Nation: Outsiders in American History. Cambridge: Harvard University Press, 2007.

Keil, Hartmut. "Alexander von Humboldt, the German Immigrant Community, and Antebellum Politics." Przegl ogon ad polonijny 31, no. 4 (2005): 7-21.

Keil, Hartmut. "Continuity and Change in the Transfer of Ideologies." Occasional Papers of the German Historical Institute, no. 7 (1992): 21-24.

Keil, Hartmut. "German Immigrant Workers in Nineteenth-Century America: Working-Class Culture and Everyday Life in an Urban Industrial Setting." In America and the Germans, Volume I: An Assessment of a Three-Hundred Year History. Edited by Frank Trommler and Joseph McVeigh. Philadelphia: University of Pennsylvania Press, 1985: 189-206.

Keil, Hartmut."German Socialist Emigrants to the United States in the Second Half of the Nineteenth Century," in Transatlantic Cultural Contexts: Essays in Honor of Eberhard Brüning. Edited by Hartmut Keil. Tübingen: Stauffenburg Verlag Brigitte Narr GmbH, 2005: 187-204.

Keil, Hartmut. German Workers' Culture in the United States, 1850-1920. Washington, D.C.: Smithsonian Institution Press, 1988.

Kennedy, Philip W. "The Know-Nothing Movement in Kentucky: Role of M.J. Spalding, Catholic Bishop of Louisville." Filson Club Historical Quarterly 38, 1964: 17-35. 
Keyssar, Alexander. The Right to Vote: The Contested History of Democracy in the United States. New York: Basic Books, 2000.

Kleber, John E. "Immigration, Xenophobia, and Bloody Monday." In Germans in Louisville: A History. Charleston, SC: Heritage Press, 2015: 22-33.

Klotter, James C., and Craig Thompson Friend. A New History of Kentucky. Lexington: University of Kentucky Press, 2018.

Kubala-Mott, Edna. "Butchertown." In Germans in Louisville: A History. Charleston, SC: Heritage Press, 2015: 111-116.

Lacquer, Walter. A History of Terrorism. New York: Little, Brown \& Co., 1977.

Lacquer, Walter. "Karl Heinzen and the Origins of Modern Terror." In The Political Psychology of Appeasement: Finlandization and Other Unpopular Essays. New Brunswick \& London: Transaction Publishers, 1980: 81-94.

Langewiesche, Dieter. Liberalism in Germany. Princeton: Princeton University Press, 2000.

Langewiesche, Dieter. "Revolution in Germany: Constitutional State, Nation State, Social Reform." In Europe in 1848: Revolution and Reform. Edited by Dieter Dowe. New York: Berghahn Books, 2001: 120-43.

Lee, Loyd E. "Baden between Revolutions: State-Building and Citizenship, 1800-1848." Central European History 24, no. 3 (1991): 248-67.

Leonard, Ira M. and Robert D. Parmet. American Nativism, 1830-1860. New York City: Van Nostrand Reinhold Company, 1971.

Levine, Bruce. "Free Soil, Free Labor, and Freimanner: German Chicago in the Civil War Era." In German Workers in Industrial Chicago, 1850-1910: A Comparative Perspective. Edited by Hartmut Keil and John B. Jentz. DeKalb: Northern Illinois University Press, 1983: $163-82$.

Levine, Bruce. "The Migration of Ideology and the Contest Meaning of Freedom: German-Americans in the Mid-Nineteenth Century." Occasional Papers of the German Historical Institute, no. 7 (1992): 5-19.

Levine, Bruce. The Spirit of 1848: German Immigrants, Labor Conflict, and the Coming of the 
Civil War. Urbana: University of Illinois Press, 1992.

Logan, Dana W. "Republicanism: Religious Studies and Church History meet Political History," Church History. Sept. 2015, 84/3, 621-624.

Mabogunje, A. J. "Systems' Approach to a Theory of Rural-Urban Migration." Geographical Analysis 2.1 (1970): 1-18.

Mallalieu, William. "George D. Prentice: A Reappraisal Reappraised." The Register of the Kentucky Historical Society 64, no. 1 (1966): 44-50.

Mangalam, J. J. and H.K. Schwarzweller. "General Theory in the Study of Migration: Current Needs and Difficulties." International Migration Review 3 (1968): 3-18.

McGann, Sister Agnes Geraldine. Nativism in Kentucky to 1860. Washington D.C.: Catholic University Press, 1944.

Miller, Martin. "The Intellectual Origins of Modern Terrorism," in Terrorism in Context. Edited by Martha Crenshaw. University Park: Pennsylvania State University Press, 1995: 27-62.

Mittlebeeler, Emmet. "The Aftermath of Louisville's Bloody Monday Election Riot of 1855." The Filson Club History Quarterly 66, no. 2 (April 1992): 197-219.

Moltmann, Günter. "The Pattern of German Emigration to the United States in the Nineteenth Century." In America and the Germans, Volume I: An Assessment of a Three-Hundred Year History. Edited by Frank Trommler and Joseph McVeigh. Philadelphia: University of Pennsylvania Press, 1985: 14-24.

Nadel, Stanley. Little Germany: Ethnicity, Religion, and Class in New York City, 1845-80. Urbana: University of Illinois Press, 1990.

Nagel, Daniel. "The German Forty-Eighters' Critique of the U.S. South.” In The U.S. South and Europe: Transatlantic Relations in the Nineteenth and Twentieth Centuries. Edited by Cornelius A. Van Minnen and Manfred Berg. Lexington: University of Kentucky Press, 2013: 51-71.

Neumann, Sigmund. "The Structure and Strategy of Revolution: 1848 and 1849." The Journal of Politics 11, no. 3 (1949): 532-44.

Nipperday, Thomas, and Daniel Nolan. “The Revolution of 1848-49.” In Germany from 
Napoleon to Bismarck: 1800-1866. Princeton: Princeton University Press, 1996: 527-98.

O’Toole, William, and Charles E. Aebersold. "Research Note: Louisville's Bloody Monday Riots from a German Perspective." Filson Club History Quarterly 70 (October 1996): $419-425$.

Peterson, Brent O. Popular Narratives and Ethnic Identity: Literature and Community in Die Abendschule. Ithaca: Cornell University Press, 1991.

Prahl, Augustus J. "The Turner.” In The Forty-Eighters: Political Refugees of the European Revolution of 1848. Edited by A.E. Zucker. New York: Columbia University Press, 1950: 79-110.

Ramage, James. Kentucky Rising: Democracy, Slavery, and Culture from the Early Republic to the Civil War. Lexington: University of Kentucky Press, 2011.

Rodgers, Daniel. "Republicanism: The Career of a Concept.” Journal of American History 79, no. 1 (June 1992): 11-38.

Ross, Steven Joseph. Workers on the Edge: Work, Leisure, and Politics in Industrializing Cincinnati, 1788-1890. New York: Columbia University Press, 1985.

Rowan, Steven. "The German Press in St. Louis and Missouri in the Nineteenth Century: The Establishment of a Tradition." The Papers of the Bibliographical Society of America 99, no. 3 (2005): 459-467.

Salafia, Matthew. Slavery's Borderland: Freedom and Bondage along the Ohio River. Philadelphia: University of Pennsylvania Press, 2013.

Schinnerer, Otto Paul. Karl Heinzen: Reformer, Poet, and Literary Critic. Chicago: University of Chicago Press, 1915.

Seiffertt, Gordon A. "Protestant Churches." In Germans in Louisville: A History. Charleston, SC: Heritage Press, 2015: 55-62.

Selle, Conrad D. and Peter R. Guetig. "Breweries." In Germans in Louisville: A History. Charleston, SC: Heritage Press, 2015: 88-95.

Shore, Elliott. "Introduction: A New Look at the Nineteenth Century." In The German-American 
Encounter: Conflict and Cooperation between Two Cultures, 1800-2000. Edited by Frank Trommler and Elliott Shore. New York: Berghahn Books, 2001: 3-5.

Shore, Elliott, Ken Fones-Wolf, and James Philip Danky. The German-American Radical Press: The Shaping of a Left Political Culture, 1850-1940. Urbana: University of Illinois Press, 1992.

Sperber, Jonathan. Rhineland Radicals: The Democratic Movement and the Revolution of 18481849. Princeton: Princeton University Press, 1992.

Sperber, Jonathan. The European Revolutions, 1848-1851. Cambridge: Cambridge University Press, 2005.

Thelan, David. "Of Audiences, Borderlands, and Comparisons: Toward the Internationalization of American History." Journal of American History 79 (1992): 432-62.

Thompson, Lawrence S. and Frank X. Braun. "The Forty-Eighters in Politics.” In The Forty-Eighters: Political Refugees of the German Revolution of 1848. Edited by A.E. Zucker. New York: Columbia University Press, 1950: 111-156.

Tóth, Helén. An Exiled Generation: German and Hungarian Refugees of Revolution, 1848-1871. Cambridge: Cambridge University Press, 2014.

Towers, Frank. The Urban South and the Coming of the Civil War. Charlottesville: University of Virginia Press, 2004.

Traugott, Mark. The Insurgent Barricade. Berkeley: University of California Press, 2010.

Vick, Brian. Defining Germany: The 1848 Frankfurt Parliamentarians and National Identity. Cambridge: Harvard University Press, 2002.

Wittke, Carl. Against the Current: The Life of Karl Heinzen (1809-80). Chicago: University of Chicago Press, 1945.

Wittke, Carl. "Karl Heinzen's Literary Ambitions." Monatshefte für Deutschen Unterricht 37, no. 2 (1945): 88-98.

Wittke, Carl. Refugees of Revolution: The German Forty-Eighters in America. Philadelphia: University of Pennsylvania Press, 1952. 
Wittke, Carl. "The German Forty-Eighters in America: A Centennial Appraisal." The American Historical Review 53, no. 4 (1948): 711-725.

Wittke, Carl. The German Language Press in America. Lexington: University of Kentucky Press, 1957.

Wittke, Carl. The Utopian Communist: A Biography of Wilhelm Weitling, Nineteenth-Century Reformer. Baton Rouge: Louisiana State University Press, 1950. 